
POrAL ONBPAPR 
Digitized by the Internet Archive in 2011 with funding from University of Toronto 
CONTRIBUTIONS OF THE

ROYAL ONTARIO MUSEUM OF ZOOLOGY

No. 4: A FAUNAI INVESTIGATION OF LONG POINT AND VICINITY, NORFOLK COUNTY, ONTARIO By L. I. Snyder.

(Reprinted from Pransactions of the Royal Canadian Institute, Vol. XVIII, Part 1, pp. 117 to 236). 


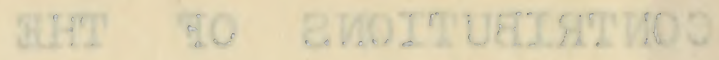
YDOJOOS TO MUREUM OIFATHO IAYOH

TVIO DHOI TO MOITADITEFVUI BAVUAF A :A .OV

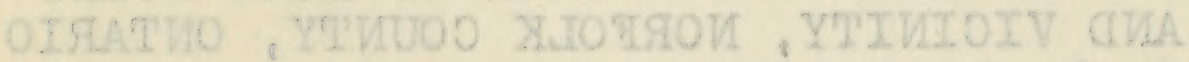
. Tobvara oI . I ve

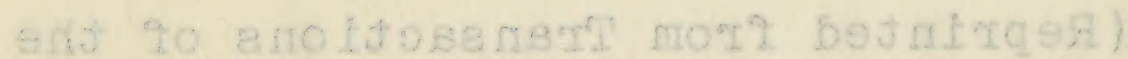

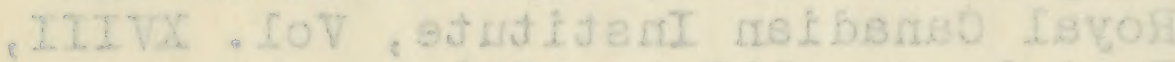
- (oES oj RLL. qq if JTES

Lege 


\title{
A FAUNAL INVESTIGATION OF LONG POINT AND VICINITY, NORFOLK COUNTY, ONTARIO*
}

\section{GENERAL INTRODUCTION}

\author{
By L. L. SNYDER
}

Long Point, on the north shore of Lake Erie, is one of the southernmost points of Ontario and of the Dominion of Canada. Although it is within the historically old and settled part of the province, its fauna has received comparatively little study. Consequently, concerned as we are with a general survey of the fauna of Ontario, the area appeared to present features which made it desirable to pursue investigations there. The following accounts are largely in the nature of reports on prevailing conditions and the higher forms of life found during field work in 1927 and 1928 , but information from published literature and other sources has been included.

Since the broad basin of Lake Erie is a comparatively shallow depression in deep soils, only slight irregularities in its shore have been necessary to provide the mechanism for the building of spits and bars by wave and wind action. A nearly straight shore-line, extending approximately forty-five miles from the westward, is terminated at a point in Walsingham township (south), Norfolk county. Silt-charged water, moving eastward, has tended to cut across the bay which is formed by the northward bending of the lake's outline at this point. Here the waves have deposited their load, forming an embankment which by continued wave and wind action has become a spit, approximately twenty miles in length. The outline of this spit is, of course, changing in detail but it may be described as being continuous and straight on the lakeward side while the inner portion is extremely irregular (see Fig. 6). At its widest section, measured across the marshy islands, the distance is approximately three miles. The most of the area, excepting the lakeward beach, is diagonally furrowed and ridged with lagoons and wet flats, and wooded sand dunes (see map, and Figs. 4 and 5).

On de Galinée's map of 1670 this spit is grossly indicated and named the "Peninsula of Lake Erie" (Coyne, 1902). On a map dated 1763

*Contribution No. 4, Royal Ontario Museum of Zoology. 
(Charlevoix, 1766) it is indicated as "Long Pt.". Later it was known as "North Foreland" (Smyth, 1799). The peninsula is now generally known as Long Point.

On early maps such as de Galinée's and that of H. Chewitt's of 1794 (Cruikshank, 1925) the point is shown connected to the mainland. Later a break through occurred at the base (Smyth, loc. cit.) and for a time thereafter the area was referred to as "Long Island". At the present time the dividing channel has filled in and the inner bay has no circulation of water from that source.

Long Point bay has an open expanse to the eastward but at its middle it is constricted by Ryerson's island (also known as Big island), a land area apparently formed by wave action, and Turkey point on the mainland. A reef has formed between Pottohawk point, on Ryerson's island and Turkey point, and at one time marshy islands were present along this line (Smyth, loc. cit.). These barriers have effectively created an inner and an outer bay. The inner bay is slowly filling in by the gradual accumulation of vegetable materials and by soil which is carried down by streams from the mainland. The pocketing of this area behind Long Point has given rise to the prevailing marsh condition (see Fig. 9) which in turn has become the habitat for a fauna which so largely characterizes Long Point.

In the early seventeen-nineties the area received attention from Lieutenant-Governor Simcoe as a possible situation for settlement and fortification. The first land grants made in Walsingham township were in June, 1796. The point itself was at one time somewhat developed for agriculture. Hall (1818) states that the "finest farms in the province" were to be found there. However, hardly a trace of these remain today, and it would appear, from the nature of the area, that these farms were small and not of a type which could be considered of the "finest" at the present time.

A mariner's light was formerly maintained at the base of the point near the old channel and later one was installed on the extremity of the point (Smith, 1851). A large modern light which is now situated on the end of the point (see Fig. 2) replaces both of these in function. This light is responsible for heavy casualties among migrating birds (Lewis, 1927, and Saunders, 1930); additional details in this regard will be mentioned in the following paper dealing with birds. The keeper of this light is the only long-period resident on Long Point at the present time, although in season, sportsmen, fishermen, and game-keepers employed by private clubs, reside there.

An interesting and well illustrated account of the history of Long Point, particularly as to its prominence in the story of Great Lakes navigation, has been published by Knister (1931). 
The Long Point Company, a long established shooting club, has control of the greater percentage of area of the point. It protects the game out of season and enforces certain rules governing shooting by its members. Other clubs, such as the Rice Bay Club, have similar organizations. A few permanent buildings are maintained for use in the fall. The shooting of waterfowl has, since early times, been the outstanding claim for distinction of Long Point. The adjacent mainland, however, is notable, perhaps more particularly of recent years, as a fine agricultural centre.

It is apparent that the climate of the region is somewhat moderated by the influence of the lake. Crops cultivated on the north shore of Lake Erie are commonly of a sort which demand a moderate climate. The county of Norfolk has recently been found to be suited for the cultivation of tobacco and fruits such as strawberries and apples are grown there extensively. Consultation of isothermal maps show that the area of Long Point has an average annual temperature of $48^{\circ}$ while the average temperature for the month of January is $25^{\circ}$ and that for July is approximately $72^{\circ}$.

The sandy ridges which run diagonally across Long Point are wooded. The relative abundance of the constituent species of the forest has doubtless been greatly altered since Long Point's early history by fire (see Fig. 3), cutting and other causes, but at the present time the forest may be described as an assortment of deciduous and evergreen trees, the former perhaps dominating the area as a whole, especially on the dry ridges. A brief description (Boughner, 1898) states that the forest at that time was dense with "cedar and birch. These two trees are the most common on the island, although red cedar is a close second. Oak is abundant and pine was originally, but was removed about thirty years ago." White cedar and paper birch are still to be found, as is also red cedar, but the latter is certainly rare as compared with earlier times. Oaks of several species including red, white, swamp white, and black, are to be found, as are also red maple, sugar maple, white ash, beech and willows. Other species found in smaller numbers are hop hornbeam, large-toothed aspen, butternut, basswood, white elm, hackberry, sycamore, tulip tree, etc. In some places fairly pure stands of small tamarac are found in wet hollows, and along the beaches and on sandy islands cottonwood is well established (see Fig. 8). Sassafras attains tree proportions on the point.

Generally speaking, there is little undergrowth beneath the forest (see Fig. 7). Two causes seem apparent. The point has been stocked with deer, which have multiplied to such numbers as to have almost completely removed the lower growth in the forest on which they browse. This effect has not been extended so completely to Ryerson's 
island which is sufficiently isolated by marshes from the main forest to have been fairly free of browsing deer. The other cause concerns the density of overhead foliage: light is so greatly reduced in some places as to effectually suppress plant growth on the forest floor. Witch hazel is perhaps the commonest shrub to be found in the forest and, in the wet hollows between ridges, buttonbush is the principal shrub. On Ryerson's island (see Fig. 1) and in a few other more or less isolated situations, dense growths of wild grape and choke cherry are found. Dwarf juniper is found on some of the beach sand dunes. Other shrubs and vines which are numerous enough to be worthy of mention are highbush cranberry, alternate-leaved dogwood, climbing bittersweet, Virginia creeper, poison ivy, gooseberry, red raspberry and blackberry.

Original forest conditions are largely destroyed on the adjacent mainland although fairly extensive plots are still to be found consisting largely of hardwood trees. Around Port Rowan nut trees such as the sweet chestnut and hickories are to be found. Early accounts of the region mention "walnuts" and this tree is now found on the mainland perhaps in greater numbers than formerly since planting has been done in many places. Reforestation and forestry experimental plots are now located within Norfolk county, which county leads the province in this respect.

Port Rowan is the largest town within the area considered in the following papers. It is located at the base of inner Long Point bay. A branch line of the Canadian National railway reaches it from the county seat at Simcoe. A population of 672 was reported for Port Rowan in the census of 1921.

\section{Previous work}

Only one section of the north shore of Lake Erie has previously received particular attention in the way of faunal survey work. Point Pelee, a peninsula situated near the western extremity of the lake, has been visited by a number of naturalists and several publications record the results of investigations there, the more noteworthy of these being by Taverner and Swales (1907-1908), Saunders (1909a and 1909b), Wood (1910), Dodge (1914), Taverner (1914), and Logier (1925). These references are of particular interest in connection with an investigation of Long Point and vicinity.

A contribution to the ornithology of the general region which has an important relation to work on the birds of Long Point is that of Todd (1904) on the birds of Erie and Presque isle, on the southern shore of Lake Erie.

Concerning Long Point and adjacent territory, it may be said that 
although several early historic accounts mention the occurrence of a number of species of plants and animals (mostly game) which were indigenous to the area, they can scarcely be construed as studies and their contents require no further reference here. Some of these will receive citation in the specific accounts in the reports which follow.

A probable source of information which the writer has not been able to search is one of the personal journals of William Pope, a naturalistartist who lived at Port Ryerse. One volume of Pope's diary covering about two years, however, is safely housed in the Public Reference Library at Toronto. A publication concerning Pope's paintings of birds and mammals by Locke (1917) receives frequent reference in the texts.

So far as the writer is aware, the earliest publications which deal particularly with the life of Long Point are those of Boughner (loc. cit.) and Macoun (1898). Boughner has presented a short paper dealing with the flora of the point, while Macoun has edited observation-notes on birds, which were made by the former during the month of June in 1898.

Several naturalists, principally interested in birds, have been attracted to Long Point during the past thirty years. Although there has been little mention of the area in publications as a result of these visits, these observers have made personal record of conditions to be found there. Mr. W. E. Saunders of London, Ontario, has perhaps kept most closely in touch with conditions on the point since 1908. He has recently published an account (1930) of birds killed at the Long Point lighthouse. Others who have gained some appreciation of the area are: Mr. W. E. Clyde Todd of Pittsburg who visited there in 1907, Mr. James Savage of Buffalo, who visits the marshes periodically for duck shooting, and Mr. John Townson of Toronto, who also has hunted there in the fall for several years. Many other individuals have made one or more trips to the area, and have become acquainted with conditions in certain sections. It has remained for members of the staff of this Museum to make a more intensive study of Long Point.

\section{Life Zone and Faunal Area}

A consideration of the flora and fauna of Long Point and vicinity discloses a rather marked tendency towards southern conditions. This is not as obvious as in sections of the north shore of Lake Erie to the westward, such as Point Pelee, but it is apparent that southern conditions are more marked than is expected in the centre of the transitional life zone. There are restricted portions of the point which appear to be fairly typical of the Austral zone, but the writer is not inclined to consider the area as a whole to be representative of that zone. The inclusion of 
meteorological data (Klugh and McDougall, 1924) with biological data, apparently strengthens the evidence which favours the area of Long Point and vicinity being considered as within the Carolinian faunal area of the Austral life zone.

In a foregoing paragraph dealing with the forest of the region a number of species of trees were listed, which have a southern distribution. We have the statement of Boughner (loc. cit.) that red cedar (Juniperus virginiana) was formerly abundant. That species, and others, such as swamp white oak (Quercus bicolor), black oak (Quercus velutina), hackberry (Celtis occidentalis), sycamore (Platanus occidentalis), cottonwood (Populus deltoides), tulip tree (Liriodendron tulipifera), sweet chestnut (Castanea dentata), and sassafras (Sassafras variifolium) of tree proportions, are not to be found extensively farther north in the longitude of southern Ontario. Many additional species found on the point are to be expected under Carolinian conditions but they normally range through Alleghanian areas as well. Among the shrubs, the buttonbush (Cephalanthus occidentalis) is characteristically southern. A marsh plant known generally as lotus (Nelumbium luteum) which is usually associated with southern conditions is to be found on Long Point in Rice bay. It also occurs on the mainland borders of Long Point bay but according to Mr. C. M. Baldwin, it is nowhere as common as it was formerly.

Concerning the mammals which have been found resident in the area, the little short-tailed shrew (Cryptotis parva), is the only species typical of a Carolinian fauna.

In regard to the bird-life of the region, the matter is complicated. It is apparent from the occurrence of such species as the orchard oriole (Icterus spurius), Bachman's sparrow (Peucea astivalis bachmanii), cerulean warbler (Dendroica carulea), yellow-breasted chat (Icteria virens), and Carolina wren (Thryothorus ludovicianus ludovicianus), etc., some of which may be regular summer residents, that the area is suitable to the existence of southern forms. Their scarcity on Long Point proper, as noted by us, may be due in part to local habitat conditions which have no relation to the basic factors controlling northern limitation of range, but the fact that these and other southern species, were comparatively scarce suggests that they have reached the periphery of their range, their centre of abundance being to the south. It is of interest to note that species such as the cardinal (Cardinalis cardinalis cardinalis), field sparrow (Spizella pusilla pusilla) and mourning dove (Zenaidura macroura carolinensis), are more common on the mainland than on the point proper. The occurrence of a few northern types is of especial interest. The moderating effect of Lake Erie must tend to prohibit extremely high temperatures in summer, and consequently the area is 
tolerable to such species as the white-throated sparrow (Zonotrichia albicollis), Blackburnian warbler (Dendroica fusca), and the blackthroated green warbler (Dendroica virens), their centre of abundance being in more boreal regions. The greater proportion of the summer resident avifauna, however, is of species which range northward through the Alleghanian faunal area. Under original conditions, before the forest was cleared from the vicinity of Long Point and contiguous areas generally, it is doubtful whether the bird-life would have appeared characteristically Carolinian.

Two representatives among the reptile life of the region are worthy of mention as indicating southern tendencies-the soft-shelled turtle (Amyda spinifera), and the hog-nosed snake (Heterodon contortrix). Fowler's toad (Bufo fowleri), is a southern representative among the amphibians, and the banded pickerel (Esox americanus), is a species of fish of southern distribution which has been recorded from Long Point bay (Allin, 1930).

In conclusion it might be said that, if the boundaries of life zones in Ontario were to be indicated by narrow lines, the present conditions of Long Point and vicinity would perhaps best be suggested by indicating the area as within the Carolinian life zone, but if a less hard and fast system is employed, Long Point should be considered as within the boundary between typical Alleghanian and Carolinian conditions. The writer is of the opinion that original conditions, before the land was cleared for cultivation, were representative of what is usually interpreted as transitional; southern animals and plants were present, as would be expected. Since then, after the clearing of the land, additional southern forms, more particularly creatures of recognized mobility, have doubtless come to occupy the area.

\section{Acknowledgements}

A most helpful contribution to the Museum's work on Long Point has been made by the Long Point Company through their officers, particularly the late Mr. H. B. Johnston, and their representative, Mr. C. H. Ferris. When the work was first suggested to them they offered the use of their keepers' cabins as camps, and when the work was initiated they put at our disposal considerable equipment such as punts, etc. The success of our expeditions was in no small measure due to the assistance of this organization and the thanks of our institution and the personnel of our field parties are here extended.

Members of the Rice Bay Club have also been interested and helpful in our work. Mr. C. M. Baldwin, and Mr. T. W. Jull, have contributed 
specimens to the collection and the former has communicated information of much benefit in camp and during the preparation of this report.

In pursuing a work such as a faunal survey it has always been found that the courtesies and accommodations extended by local residents are notable aids to the work. Such considerations were frequently given our party by Mr. J. Biddle of Port Rowan. Also the local fishermen whom we met, contributed much to an early acquaintance with prevailing conditions and assisted us in many ways. Mr. Geo. Barnes, Mr. Roy Ferris, and Mr. Wm. Snooks, were particularly helpful to us while in camp on Long Point.

Lastly, the writer of this brief introduction wishes to thank the other members of the Museum's field party and visitors to our camps, for their co-operation in the work. He wishes also to acknowledge his indebtedness to Mr. J. H. Fleming and Mr. J. L. Baillie, Jr., for references to historical accounts dealing in part with Long Point.

\section{LITERATURE CITED}

Allin, A. E. 1930. Extension of range of Esox americanus (Gmelin). Can. Field-Nat., $44: 21$.

Boughner, L. J. 1898. Notes on the flora of Long Point island, Lake Erie, province of Ontario, Canada. Ottawa Nat., 12:105.

Charlevoix (Father). 1766. A voyage to North America: undertaken by the command of the present King of France. Vol. 1. Dublin.

Coyne, James H. 1902. Galinée's narrative and map; with an English version, including all the map-legends. Ont. Hist. Soc., Papers and Records. Vol. 4.

Cruikshank, Brig.-Gen. E. A. 1925. The correspondence of LieutenantGovernor John Graves Simcoe, 3:142. Ont. Hist. Soc., Toronto.

Dodge, C. K. 1914. Annotated list of flowering plants and ferns of Point Pelee, Ont., and neighbouring districts. Dept. Mines, Geol. Surv. Mem. 54, Biol. Series, No. 2. Ottawa.

Hall, Lieut. Francis. 1818. Travels in Canada and the United States in 1816 and 1817. p. 203. London, Eng.

Klugh, A. B. and E. G. McDougall. 1924. The faunal areas of Canada. Handbook of Canada, pp. 195-206. Toronto.

Knister, Raymond. 1931. Long Point, Lake Erie. Can. Geographical Journ. 2:72-82.

Lewis, H. F. 1927. Destruction of birds by lighthouses in the provinces of Ontario and Quebec. Can. Field-Nat., 41:76.

Locke, Geo. H. 1917. Water colour drawings by William Pope. Public Library, Toronto. 
Logier, E. B. S. 1925. Notes on the herpetology of Point Pelee, Ont. Can. Field-Nat., 39:91-95.

Macoun, W. T. 1898. Birds' nests and breeding places. Ottawa Nat., $12: 88-89$.

Saunders, W. E. 1909a. Winter birds at Point Pelee. Ottawa Nat., $23: 47-50$.

Saunders, W. E. 1909b. Rare birds at Point Pelee. Ottawa Nat., 23 : $161-167$.

Saunders, W. E. 1930. The destruction of birds at Long Point lighthouse, Ont., on four nights in 1929. Auk 47:507-511.

Smith, W. H. 1851. Canada: past, present, and future. Vol. 1, p. 126. Toronto.

Smyth, D. W. 1799. A short topographical description of His Majesty's province of Upper Canada in North America, pp. 35-36. London, Eng.

Taverner, P. A. and B. H. Swales. 1907-1908. The birds of Point Pelee. Wilson Bull., 19:37-54, 82-99 and 133-153; 20:79-96 and 107-129.

Taverner, P. A. 1914. Geological survey museum work on Point Pelee, Ont. Ottawa Nat., 28:97-105.

Todd, W. E. Clyde. 1904. The birds of Erie and Presque isle, Erie county, Pa. Annals Carnegie Museum, 2:481-596.

Wood, N. A. 1910. Bird migration at Point Pelee, Ont., in the fall of 1909. Wilson Bull., 22:63-78. 



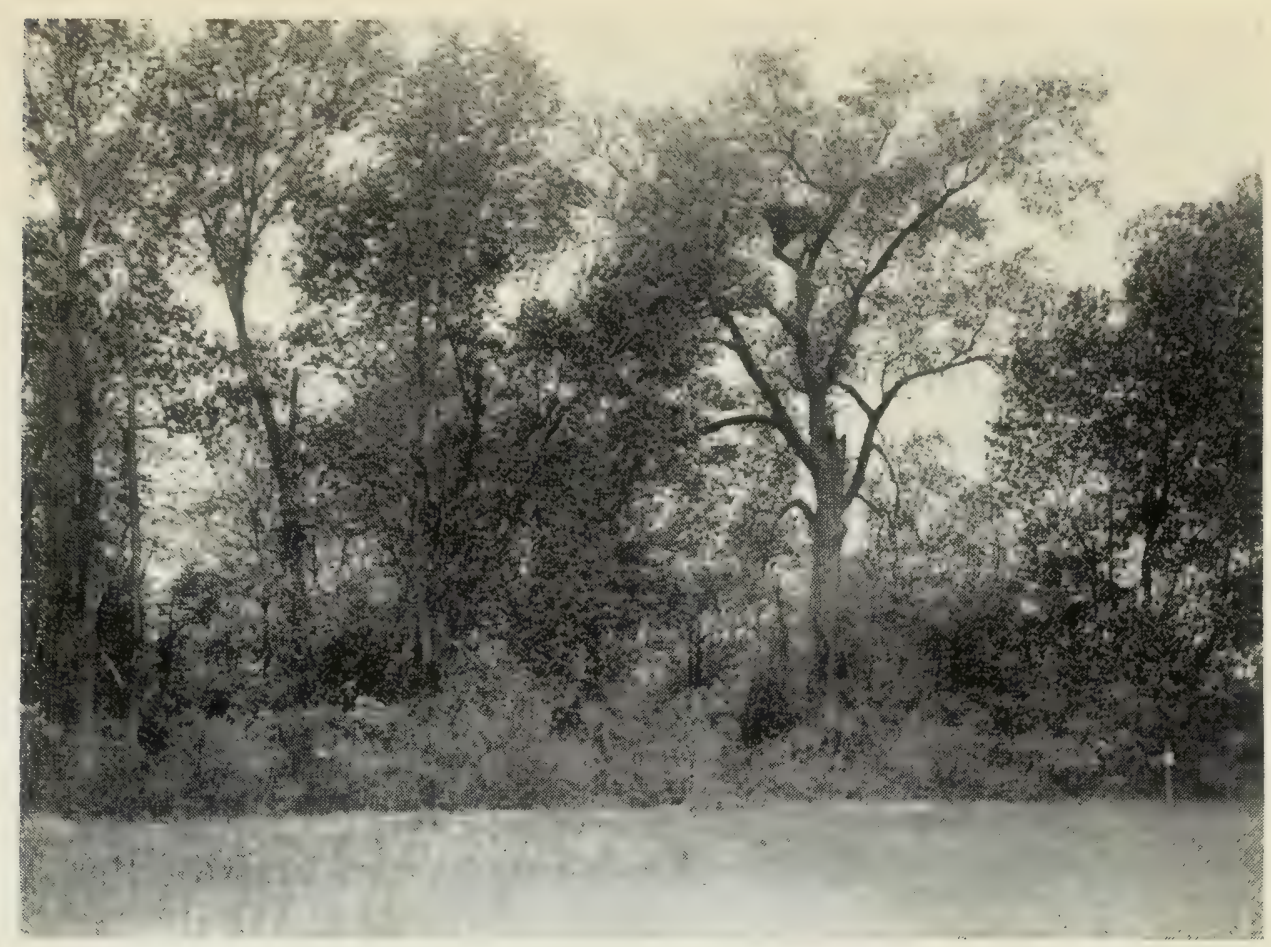

FIG. 1 Showing characteristic vegetation on Ryerson's island and nest of the bald eagle. Photo by $W . A$. Gordon
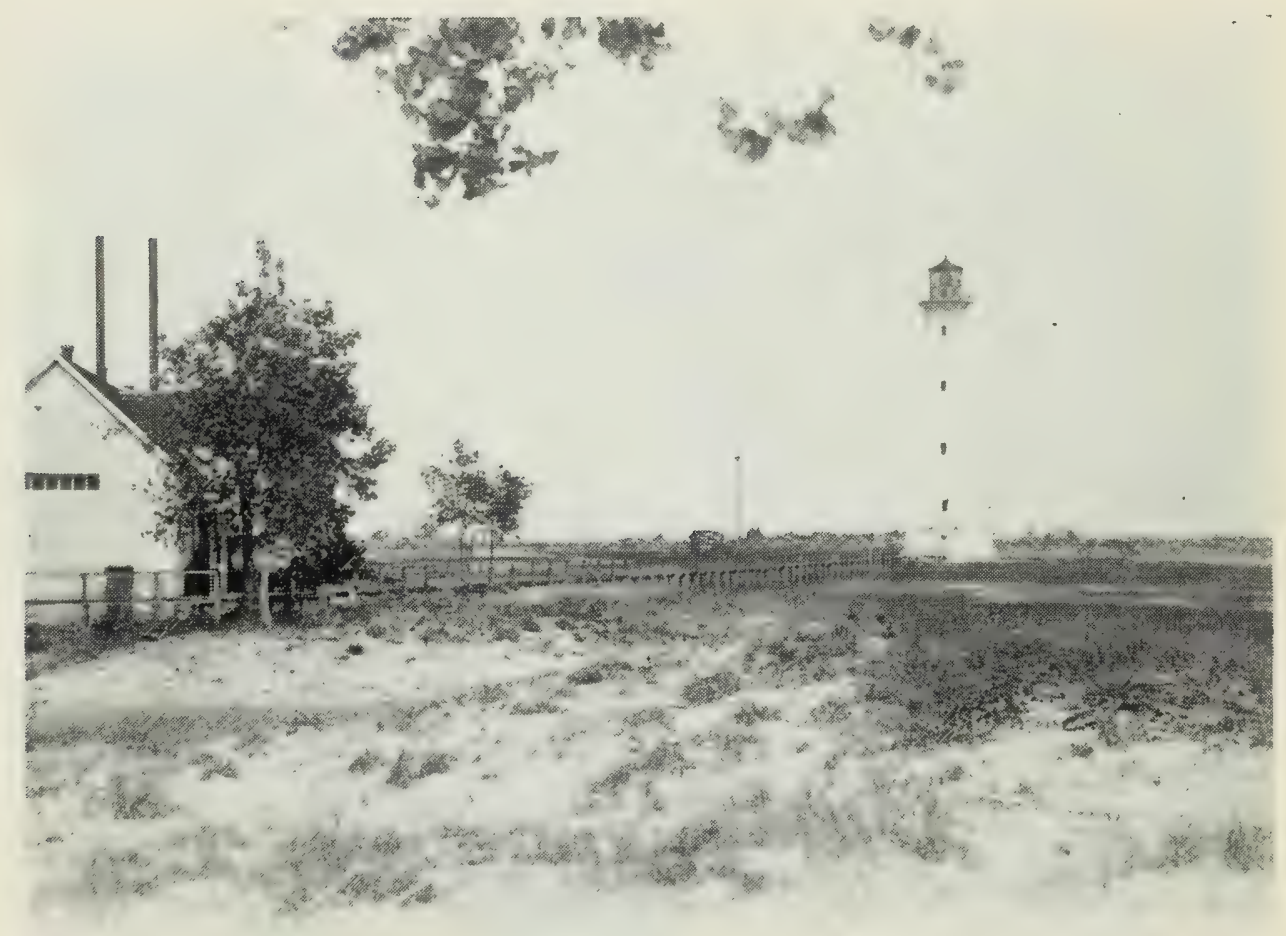

FIG. 2 Lighthouse near the east end of Long Point.

Photo by $W$. A. Gordon 



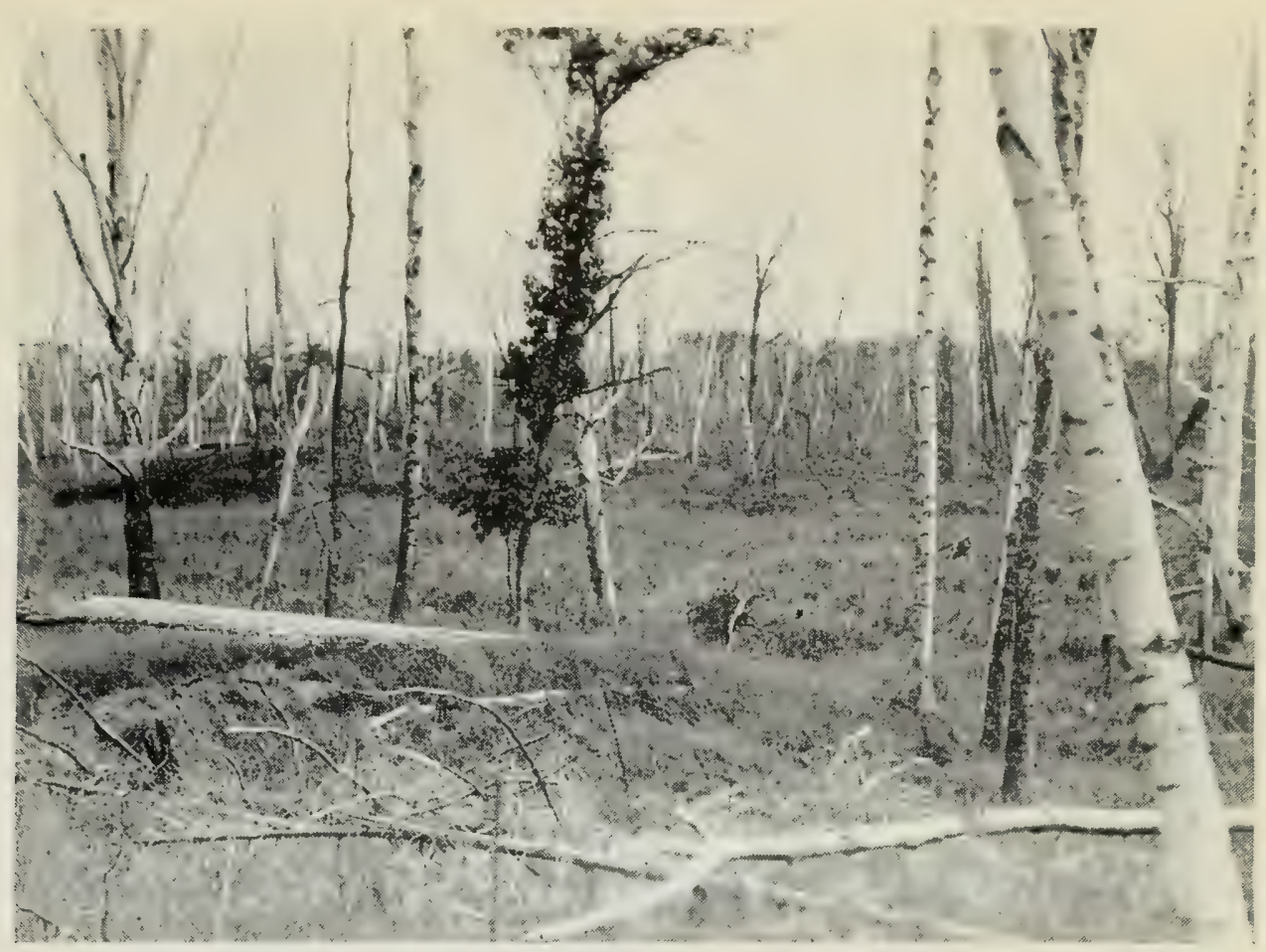

FIG. 3 View of the burnt ridges.

Photo by $W$. A. Gordon

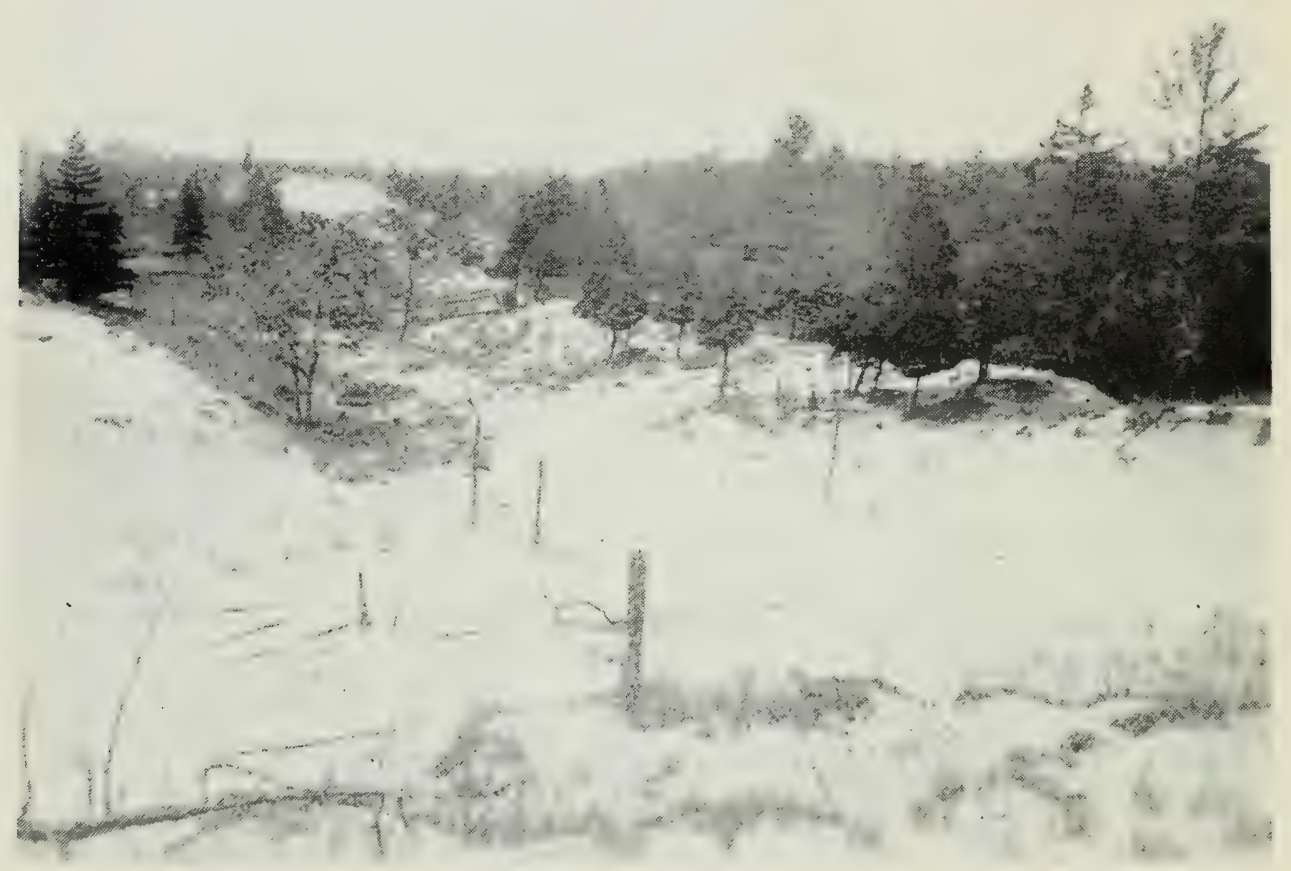

Fig 4, Typical sand dune area, near Grạvelly bay.

Photo by $W$. A. Gordon 


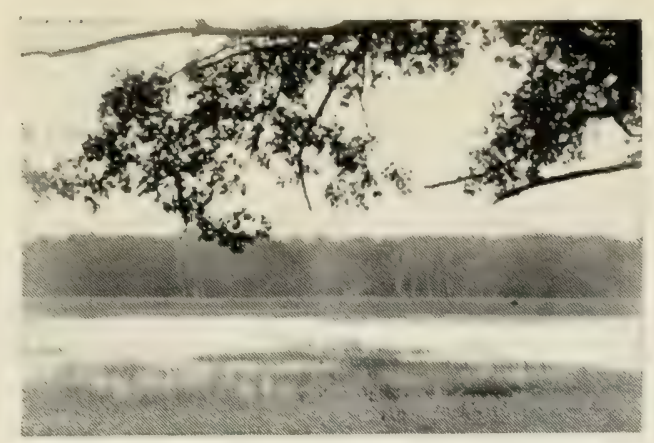

FIG. 5 Looking across lagoon from Courtright ridge toward Squire's ridge.

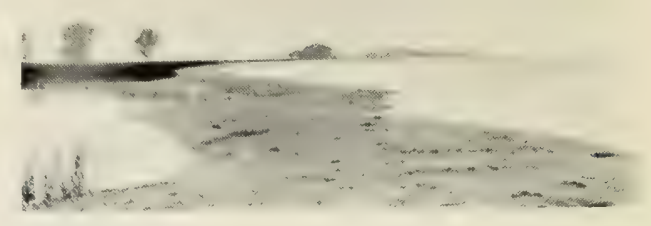

FIG. 6 Sandbar off Snow island in outer Long Point bay typical of the everchanging shoreline.

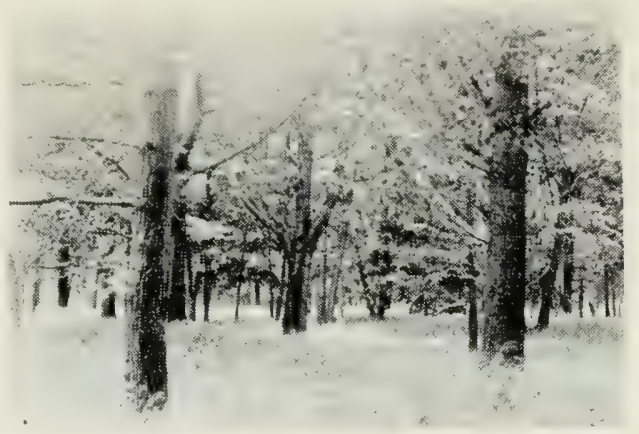

Fig. 7 Oak stand on

Courtright ridge
showing absence of undergrowth.

FIG. 8 Lake shore dune with cottonwoods in spring.

Photo by $A$. R. Van
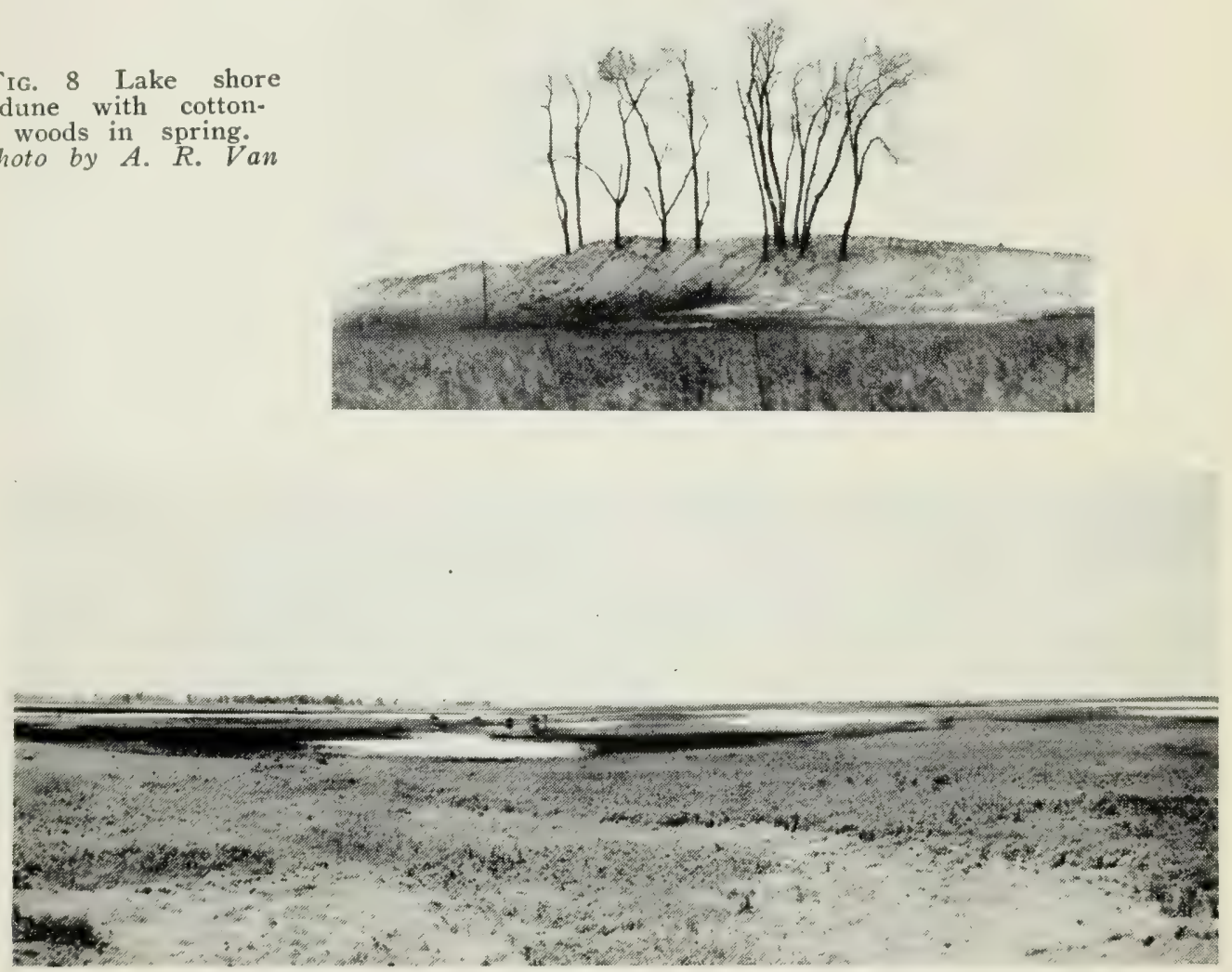

FIG. 9 A section of the extensive Long Point marsh and mud flats in spring Photo by $A, R$ Van 


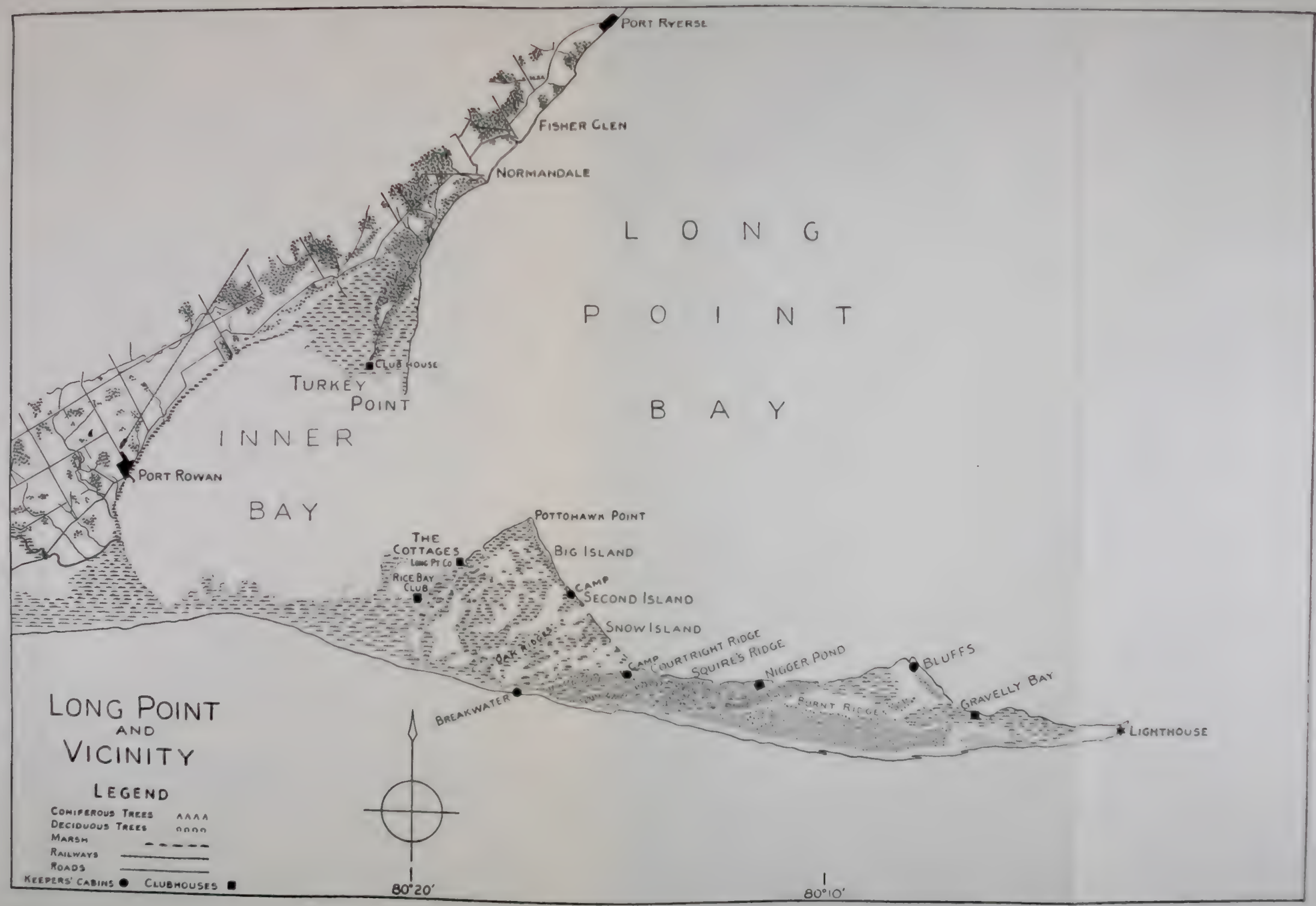





\section{A FAUNAL INVESTIGATION OF LONG POINT AND VICINITY, NORFOLK COUNTY, ONTARIO}

\section{THE MAMMALS OF LONG POINT AND VICINITY}

\section{By L. L. SNYder}

A survey of the mammal life of Long Point and vicinity was made during the summer of 1927 when a party from the Royal Ontario Museum of Zoology visited the region for the purpose of studying and making collections of the higher forms of life resident there. The party arrived at Port Rowan, which is situated on the mainland at the base of inner Long Point bay, on May 25th, and by evening of the same day was partially established in a camp on Second island of Long Point. Having remained there until June 20th camp was removed to a new locality known as Courtright ridge. From both these camps, trips were made to many sections of the point, a punt being a necessary conveyance from the Second island camp while extensive trips could be made on foot from the Courtright camp. Work during 1927 was concluded on July 26. A party from the Museum was again encamped on Long Point from May 1 to June 1, 1928, but little attention was given to mammal study. The few observations made during that month, however, are included in the paper that follows.

The major portion of the work in collecting mammal specimens was done by Mr. H. P. Stovell, a member of the staff of the Museum. His thorough attention to the work and careful preparation of material contribute largely toward the report. A few references from historical accounts, certain observations from the note-book of the writer and reports from residents of, and visitors to, the region make up the remainder of the sources on which the following text is based.

The usual method employed in collecting the smaller forms was by setting mouse-traps, but some notable results were obtained by turning over logs and drift-wood and by capturing by hand, when possible, such specimens as attempted to escape. The larger forms were secured by traps or with a gun.

The inclusion of the area adjacent to Long Point (the "vicinity") has been considered justifiable since our work on the point necessitated brief visits to the mainland, allowing limited observation, and because 
of reports from reliable persons of forms to be found there. Such reports have been mostly substantiated by specimens taken on the point itself, or have appeared otherwise to be unquestionable.

It is not professed that the following list is complete as there are a number of species which very probably occur but concerning which we secured no information. An example of this is found among the bats. Twice during the summer, a bat was noted but no specimen was secured. The observations were so fleeting as to make specific, or even group identity, uncertain, although it is almost a certainty that these individuals probably represented a species not given in the following list. Future work, especially on the adjacent mainland, will probably disclose additional species such as shrews and moles. It has been considered advisable to include species now extirpated, in the introduction rather than in the list proper.

In 1669 Dollier de Casson and de Brehant de Galinée, two French missionary priests, parted company with LaSalle with whom they had set out from Montreal to attempt to discover the river (Ohio) which was thought to empty into the gulf of California. From near the present site of the village of Hanover, Ontario, the party of twelve men proceeded to the Grand river. Three men were to go overland to the shores of Lake Erie to a point between Long Point and Rondeau to secure the canoe left there by Joliet which had been placed at their disposal. The other party, consisting of Casson and Galinée and seven men, descended the Grand river to Lake Erie. They wintered near the present town of Port Dover and in Galinée's remarkable account of their travels and experiences (Coyne, 1902) several notes concerning the wild life of the region are recorded. The region around Port Dover was a "great hunting ground for stags ("serfs"), does ("Bisches"), bears ("Ours"), red deer ("schenontons"), raccoons ("Chats Sauvages"-- see Coyne's translation), and beavers ("Castors").

On March 30, 1670, Galinée "awaited [some of his party] on a ridge of sand, which joins the peninsula of Lake Erie [Long Point] to the mainland, and separates the great from the little Lake Erie [Long Point bay]". Here his men killed a "stag". Travelling westward from Long Point the party encountered, at Rondeau, "a herd of more than two hundred "bisches" [does]. . ."and a wolf was also shot." Elsewhere in the account relating to the general region Galinée mentions the "chevreuil" (translated roe-buck or red deer). It is evident that the "serfs" (stags) refer to the wapiti which is now extirpated in Ontario. With the exception of the term "bisches" (does) the identity of the animals mentioned is obvious. It is probable that the term refers to females of the wapiti. (Elsewhere in the text, moose ("eslans") are mentioned but not associated with the Lake Erie region). Specimens of wapiti 
antlers taken on Long Point are now in the possession of Mr. M. M. Smith, who resides at Simcoe, Norfolk county (Landon, 1931). It is estimated from casual hearsay accounts that wild wapiti disappeared from the region between one hundred and thirty and one hundred and forty years ago. It is understood from conversations with local residents of Port Rowan that an attempt was made a number of years ago to reintroduce the species on Long Point, but the stock, which apparently consisted of two animals, escaped to the mainland where they were presumably destroyed.*

Most of the animals recorded by Galinée are no longer to be found in the more southern parts of Ontario generally. The red deer is the only one known to occur on Long Point, and it, either after it was totally extirpated or at a time when it was nearly so, has been reintroduced.

We heard of a recent occurrence of a wild cat on the point from a local fisherman. This incident had taken place in the winter of 1926-7, but although the animal was hunted it was never taken. It is quite possible that a wandering Lynx rufus was the basis of this report.

A more recent record for the wolf than that of Galinée's is contained in one of the diaries (now in the Public Reference Library, Toronto) of William Pope who lived at Port Ryerse. The actual taking of this specimen is recorded under the date of October 20, 1842. However, the species is no longer represented in the local fauna.

In a collection of paintings executed by William Pope (Locke, 1917) while he was resident near Port Ryerse, Norfolk county, Ontario, there are illustrations of three species of mammals not listed in the paper which follows. One of these is of the cinereous shrew (Sorex personatus $=$ Sorex cinereus), the subject probably being obtained locally within the vicinity of Long Point. This mammal is very probably found in the area at the present time but we have not secured a confirmatory record. Also Pope figured the Canada lynx (Lynx canadensis) and the varying hare (Lepus americanus) both of which were probably residents of the region during the middle of the nineteenth century and were obtainable locally by the artist. Although the lynx is now extirpated, the hare may still be found in the heavily wooded swamps of the region. Of this, however, we have not been able to make certain.

Thanks are due to various individuals for records acknowledged in the text and to other individuals who have contributed in one way or another to the mammal work. Also acknowledgement is here made to the

*Verification of the above has been found in the report of the Ontario Game and Fisheries Department for 1909 (1910) which states that "a number" of elk was introduced by the Long Point Company in 1909, one of which escaped and was killed in November of that year. 
Bureau of Biological Survey, Washington, D.C., for the determination or confirmation of the identity of specimens referred to them. These are as follows: Cryptotis parva, Tamias striatus lysteri, Sciurus hudsonicus loquax, Peromyscus maniculatus bairdii and Peromyscus leucopus noveboracensis.

In recording in the text the measurements of the specimens it may be stated that the dimensions are in millimeters taken from the animals in the flesh. The symbol L., is for the length, this measurement being from the tip of snout to the end of the tail vertebrae; $T$., is for the length of tail, from body juncture to the end of vertebrae, and H.F., is for the hind foot, from the heel to the end of the longest toe and claw.

\section{Annotated List}

Condylura cristata (Linnaeus). Star-Nosed Mole.-Not found on Long Point, but its occurrence on the mainland was established in July, 1927, when Mr. R. V. Lindsay examined a specimen which had been captured by a boy at a camp at Fisher glen. It probably inhabits other sections of the vicinity of Long Point, more particularly in swampy places.

Cryptotis parva (Say). Litrle Short-Tailed Shrew.-The taking of this animal was perhaps the outstanding event of collecting on Long Point. The record of it (Snyder, 1928) constitutes the first for Canada and its occurrence presents another of those interesting problems concerning the redistribution of animals following the retreat of the last continental ice-sheet. Accidental transport by some means such as drifting vegetation appears to be the only plausible explanation although it is admitted that this theory is already heavily taxed to explain a host of similar problems. It would seem reasonable, however, to regard Long Point as an area to which the species had spread from along the north shore of Lake Erie, either from the east or west. Accidental invasion at either end of the lake would be considerably more within the range of possibility since it would entail only the crossing of a river rather than the miles of open lake off Long Point.

On May 30, 1927, a pair of these shrews was captured by Mr. E. B. S. Logier from beneath a squared beam lying in an open area near the beach on Ryerson's island. They had constructed several tunnel runways to the outside from beneath the beam and at the inner end of one of these a depression contained a nest. The nest was constructed of dead grass and was lined with withered leaves. It was somewhat depressed but otherwise rounded in shape, measuring approximately four inches in diameter. Five other specimens were secured, two adults from beneath driftwood on the beach and three young cast up from the stomach 
of a milk snake which was being anæsthetised in camp. We were unsuccessful in securing other specimens in May, 1928, possibly their habits in spring being different from those we had found for summer. The average measurements of the four adults: L., 78.75; T., 16.5; H.F., 11.

Blarina brevicauda talpoides (Gapper). Mole Shrew.-Mr. D. A. MacLulich collected three specimens of this shrew at Turkey point on May 26 and 27, 1931. This is our only record for the region. The average measurements of these specimens: L., 115; T., 23; H.F., 13.5.

Lasionycteris noctivagans (Le Conte). Silver-haired Bat.On the night of September 25, 1929, one of these bats struck the Long Point light and was discovered by the keeper who forwarded it to $\mathrm{Mr}$. W. E. Saunders, of London. It is curious that these animals which are ordinarily so capable of avoiding disaster should lose their powers so completely under the flashes of light. One would expect a bat to alight on some part of the tower and cling in safety even though the effect of the light was blinding. It may be possible that these animals do not strike the light but are merely confounded by it to the extent of not being able to proceed on their migration and eventually exhaust themselves in confused flight. The specimen is now in the collection of Mr. Saunders.

Nycteris borealis borealis (Müller). RED BAT.-Three specimens of this species were victims of the Long Point light on September 7 or 9, 1929 (Saunders, 1930). At least one of these specimens is now in the collection of Mr. Saunders and another in that of Mr. Eli Davis of London, Ont.

Nycteris cinerea (Beauvois). HoAry Bar.-A specimen of this species now in the collection of Mr. Saunders was secured with the silverhaired bat mentioned above, following the night of September 25, 1929.

Procyon lotor lotor (Linnaeus). RAccoon.-Raccoons were not very common during the summer of 1927 , but signs of the species were noted on several occasions. For a few days following the egg-laying period of turtles (from June 22 to 24) dozens of nests of these reptiles were excavated by some beast or beasts and a search in open sandy situations revealed the tracks of raccoons going from one to another. These animals do not take all of the eggs from a nest, a few at the bottom apparently escaping their notice. It would appear that this species, and other animals, subsist almost entirely on turtle eggs for several days during mid-June. The large number of turtles to be found on Long Point is evidence that this habit among certain mammals is not a serious factor endangering the survival of turtles, it being supposed that the robbing habit has been established for a considerable time. The eggs which escape the marauders suffice to keep up their balance of numbers. The fishermen in the bay who consider the turtles a nuisance to their nets 
should conserve the raccoon population as well as that of certain other carnivores.

Mustela noveboracensis noveboracensis (Emmons). NEW YORK WeAsel.-The numbers of weasels on Long Point vary from year to year, probably as a result of trapping and also from a fluctuation of food supply. During 1927 and 1928 they were sufficiently scarce to escape detection by us but local fishermen who also trap the area in winter state that some winters produce considerable numbers. It is of interest to note that these weasels are taken in the marsh and about the marshy islands, and are not confined to the wooded sections. They also occur on the adjacent mainland, and at Turkey point they are regularly trapped for fur.

Mustela vison vison (Schreber). Mink.-Like the weasel, this animal is regularly trapped on the point but the numbers vary from year to year. It, however, is more sought after because of the value of its pelt. A method used by some of the trappers in capturing mink is to train a small dog to track them, hunt them down and kill them without injury to the skin. This practice is not only remunerative but also has some element of sport in it.

Mephitis mephitis nigra (Peale and Beauvois). Skunk.Information received by us indicates that skunks regularly inhabit the point and also the mainland. Mr. R. V. Lindsay noted the species at Fisher glen in July, 1927, and Saunders (1930) has also remarked on the presence of skunks near the lighthouse during September, 1929. We were aware of the presence of skunks during the summer of 1927, both by scent and by noting their tracks on the beach. We found this animal, like the raccoon, to be a habitual robber of turtle nests in season.

Vulpes fulva (Desmarest). RED Fox.-Local trappers informed us that at times there were quite a few foxes on Long Point. On June 29, 1927, we saw where one of these animals had trailed over the sand and examination of one place made it fairly certain that the fox too eats the freshly-laid eggs of turtles.

Marmota monax rufescens Howell. Woodchuck.-A common inhabitant of the region. On Long Point these animals find ideal conditions since the fox is probably their only enemy and burrow-making is easy since the ridges are well drained and of sandy soil. The species does not necessarily restrict itself to dry situations, however, since one individual was found inhabiting a small, low-lying island in the marsh.

While we were working in our camp on the morning of July 12,1927 , a young groundhog came through the grass to our door. Wishing to observe him for a time, two of us cut off his retreat in the direction from which he had come by the simple expedient of standing in his way. He challenged us with chattering teeth and once boldly dashed at my 
feet as if to attack. It was apparent that he was aware that safety lay only beyond us and not in other directions and he stubbornly stuck to that point of view. A stick gently pushed at his face was not attacked as one might expect but was pushed away from him with his front paws with very much the action of human hands. Needless to say he lost no time in escaping when we ceased to bar his chosen outlet of escape.

Tamias striatus lysteri (Richardson). EAstern Chipmunk.A very common mammal of the dry deciduous woods of the point and mainland. Conditions are apparently ideal for the species on the point there being few enemies and the soil and vegetation seemingly being eminently suited as a habitat. We have seen no area so thickly populated with chipmunks as the wooded ridges of Long Point during the summer of 1927. A similar status, on May 30, 1908, was noted by Mr. W. E. Saunders in his personal notes submitted for inclusion here. However, in July the dense population appears to vanish. On July 7, 1927, a special hunt for chipmunks yielded only one. However, it rained on that particular day but subsequent observations suggest that a kind of æstivation during the hot days of summer takes place.

Chipmunks were noted on several occasions demonstrating their arboreal capabilities. On July 8, Mr. J. L. Baillie noted one about thirty feet up in a tree, while finding them at lesser distances was not unusual. Another seen on the same day entered a cavity in a tree twenty feet from the ground. The absence of undergrowth food possibly has contributed toward the development of their skill in climbing. Only two of the large series of specimens were taken in clearings, the rest having been taken in wooded situations. Three females collected were bob-tailed. The average measurements of twenty-three unmutilated adults: L., 230.75; T., 85.25; H.F., 34.75.

Sciurus hudsonicus loqua: Bangs. RED SQUirRel.--The red squirrel was not common on Long Point and only a few specimens were secured. Although there is considerable individual variation in the six specimens collected they all exhibit much red on the upper parts. One young, taken on July 4, 1927, is uniformly red above, there being no pronounced dorsal stripe, and the colour is not broken by "peppered" effect due to black bands on the hair. Red squirrels occur sparingly in mixed and deciduous woods alike. The average measurements of four adults: L., 302; T., 120.5; H.F., 47.75.

Sciurus carolinensis leucotis (Gapper). GRAY OR BLACK SQUIRREL.- The species does not occur on the point but it is to be found on the mainland. Mr. C. H. Ferris states that the black phase is the more plentiful at Port Rowan but the gray is becoming more common of recent years. Mr. R. V. Lindsay did not see black individuals in 1927 at Fisher glen although the gray variety was noted. 
Glaucomys volans volans (Linnaeus). EAstern Flying SQUiRREL.- No evidence of the flying squirrel was noted by us. Mr. C. H. Ferris states that he has seen a few individuals around Port Rowan but not within the last few years. Pope has figured the flying squirrel (Locke, 1917) from an animal probably taken locally and the picture has been listed under the name Sciuropterus volans volans. The ranges of the two species occurring in southern Ontario are known in sufficient detail to make it certain that volans is the species to be expected in the Long Point region.

Peromyscus maniculatus bairdii (Hoy and Kennicott). BAIRD White-Footed Mouse.-During the summer of 1927 this mouse was a common inhabitant of open situations bordering the marsh and lake. The remarks on habitat which are included on the labels of all specimens preserved make it apparent that this species does not invade the woods, consequently, as will be pointed out in connection with the following species, $P . l$. noveboracensis, the two white-footed mice on Long Point do not come into serious competition. Driftwood and herbaceous plants are the protective covers for this mouse. The average measurements of eight adults: L., 149; T., 59.5; H.F., 18.5. The largest specimen: L., 154; T., 67; H.F., 18.

Peromyscus leucopus noveboracensis (Fischer). White-Footed Mouse.-A common inhabitant of the woods on Long Point in 1927. It is interesting to note that of the twenty-nine specimens preserved only nine were taken within the habitat of P.m. bairdii, seven of these being immature or young. It would seem that adults which are engaged in rearing young are usually confined to wooded territory or covered situations such as about buildings. These situations constitute their normal nesting habitat. On the other hand, young individuals which have not reached the reproductive age are inclined to wander and may be found in open situations with the other resident species. A great deal depends on immediate habitat conditions since adults of $P$. l. noveboracensis were also taken underneath drift cover on the beach of Ryerson's island but here the woods are so adjacent to the beach as to discount the beach as a distinct habitat. Apparently the beach of Ryerson's island was not inhabited by $P . m$. bairdii. It is also thought that occasionally adult $P . l$. noveboracensis will resort to open, even aquatic situations. On June 10,1927, a white-footed mouse was seen on top of a muskrat house in the marsh, fifty yards from any dry land. Judging from its bright colour it was thought to be an adult of this species. One specimen of this mouse which was collected had sustained a badly broken tail. This member had healed instead of sloughing off as one would have expected. The average measurements of twenty-nine 
mature specimens: L., 172.1; T., 80.3; H.F., 20.6. The largest specimen : L., 185; T., 89; H.F., 21.

Microtus pennsylvanicus pennsylvanicus (Ord). Meadow Mouse.-A common mammal in wet, grassy situations. Specimens were taken from the grass-and-sedge-flats of the marsh, in growths of horse-tail and jewel-weed and on the beaches and marsh borders from beneath protecting debris such as windrows of dead marsh vegetation. Of the fifteen specimens preserved only five are fully adult. The average measurements of these: L., 185.6; T., 54; H.F., 21.2. The largest specimen: L., 201; T., 61; H.F., 22.

Ondatra zibethica zibethica (Linnaeus). Muskrat.-This prolific fur-bearer flourishes in the extensive marshes of the point and adjacent mainland. Although the yield of furs varies from year to year according to water conditions and food supply, the trapping of muskrats is a regular source of revenue for the Long Point Company and local trappers. It has been stated (Giles, 1880) that "from 10,000 to 25,000 " rats were taken annually in favourable years. Two thousand were trapped on the Long Point Company's property in the spring of 1908, (personal notes of Mr. W. E. Saunders) and Mr. D. A. MacLulich informs the writer that sixteen hundred rats were trapped on three thousand acres of marsh at Turkey point during the spring of 1931. During the summer of 1927 muskrats were fairly numerous in the Long Point marsh and their houses were conspicuous objects here and there among the reed-beds.

On December 8, 1927, a terrific seventy-mile gale swept the Great Lakes region. The waters of Lake Erie washed over the south beach of Long Point and the entire marsh was devastated. Buildings were wrecked, boats and docks lost and low islands were scoured of their vegetation. Muskrats suffered heavy losses, eye-witnesses observing many being swept into the open bay, adrift on their houses or other floating vegetable masses. In the spring of 1928 no houses were to be seen, the remnant population of rats having taken up their abode in the windrows of dead reeds which had been swept onto the higher land areas such as Second island and Ryerson's island.

On May 27, 1927, the writer examined a muskrat house and found it to contain seven naked and blind young. When the nest was again examined on May 31, it was found that the young had been removed although the previous inspection had not seriously disturbed the nest. Two other nests examined by Mr. H. P. Stovell on June 9, 1927, contained six and five naked young respectively. Another nest examined by Mr. W. J. LeRay on July 12, 1929, contained five young. This litter was fairly well furred and able to swim.

A successful muskrat farm is now maintained on the mainland at 
the base of Long Point bay near Port Rowan. Dams and pumps keep constant water levels in a vast area of natural habitat.

According to his notes, Mr. W. E. Saunders has seen an albino muskrat taken on Long Point. Albinism in the species is apparently rare in proportion to their numbers.

The average measurements of two adult specimens collected: L., 229.5; T., 227; H.F., 73.5.

Rattus norvegicus (Erxleben). House RAT.-These animals were found living virtually in a wild state on Long Point. Their runways were found beneath outbuildings and their burrows in the ground were noted about our camps on Second island and Courtright ridge. The rat is said to be found about buildings elsewhere on the point. It is interesting to know that this animal can survive in these isolated situations where there are no human inhabitants for long periods each year. The species is supposed to have been transported accidentally to the point in shipments of freight from the mainland.

Mus musculus musculus Linnaeus. House Morse-Curiously enough we did not find this species about either of our camps at Long Point. However, it is known to occur about some of the buildings on the peninsula and it is found commonly about habitations on the mainland.

Lepus europæus europæus Pallas. European Hare.-According to Mr. C. H. Ferris this species has been found about Port Rowan since about 1924. We did not see it on the point, either in 1927 or 1928, but it is stated by Mr. Ferris that a few have now reached there.

Sylvilagus floridanus mearnsii (Allen). CотtontaIL.-Although the cottontail is to be found in suitable situations along the mainland the scarcity of undergrowth on Long Point precludes its general distribution over that area. A few are established where thickets are found, such as on Ryerson's island. It was at this place on May 9, 1928, that a family of five helpless young was found in a grass-covered form on the ground beneath a cottonwood tree. The species is a comparatively recent addition to the fauna of the area.

Odocoileus virginianus. White-TAILED DEER.-Deer were present in the general region during the time of the earliest exploration through the area. Galinée (Coyne, 1902) mentions them in his account of travel and encampment along the north shore of Lake Erie. It is probable that the animal was extirpated on the adjacent mainland before it reached its lowest numbers on the point, and there are persons who consider that wild deer were never completely extirpated from the peninsula. However, the first introduction of deer on the point was made about the year 1870 at a time when native wild deer were either extirpated or nearly so. According to an old resident of Port Rowan 
who recalled the circumstances to $\mathrm{Mr}$. C. H. Ferris, this introduction was made by the Head Gamekeeper of the Long Point Company. It is not known from where the animals used to stock the peninsula were obtained, but it is supposed that northern stock was secured since the larger size of northern individuals and their availability would favour them for game purposes. A second introduction was made in 1886, the animals being imported from Minnesota where the large northern form occurs. Since that time, about 1908, two males were released on the point from the stock in Rondeau park. These latter animals were probably not of a superior size.

At the present time deer are numerous on Long Point. During our stay in the summer of 1927 we saw them regularly at various parts of the peninsula. They were noted on a few occasions in the woods, but here there was a great scarcity of food, largely due to the overstocked condition of the area. Examination of the floor of the forest reveals signs that browsing is largely responsible for the open, park-like conditions. Early references such as that of Charlevoix (1766) state that the point "produces naturally many vines". Such a description could now apply only to a few of the more isolated knolls and islands but at the present time even these are being invaded for food. Native deer under original conditions probably had little effect on the vegetation of Long Point because the population shifted naturally to and from the mainland, but at the present time the cultivated and inhabited mainland at the base of the point is a formidable barrier and the deer are virtually confined to the point.

The original introduction of deer was for sporting purposes and they were hunted regularly in the fall for some years. At the present time there is little hunting of these animals and they have increased to maximum numbers, thus threatening their food supply. Another notable feature of the present deer population is the small size of the animals. It was estimated that no deer seen during our visit to the point would weigh more than two-thirds of the normal weight of wild, northern white-tailed deer, sex for sex. They are still wild in nature and have apparently not suffered any dulling of nervous activity by their confinement to a restricted area.

In attempting to analyze the reasons for the dwarfed size of deer on Long Point it is apparent that three factors have been working to produce this result. First, hunting is a well known agency for eliminating the larger animals which leaves those of smaller stature to reproduce. The more restricted the area, the more rapid would be the effects. Although deer are now only casually hunted, more intensive hunting in the past has had its effect. Second, at the present time the animals are very probably stunted by food shortage due to over-population. Third, 
we have a situation on Long Point where the predator on deer is nonexistent. Without the weeding out of the less vigorous and alert by natural enemies, dwarfing characteristics spread rapidly through the population in a restricted area. All individuals fortunate enough to find sulsistence have the opportunity to mate and to intermate, there being no elimination of the unfit. It is not here suggested that the introduction of a large predator would improve the situation on Long Point. Here we are dealing with too large an animal for so restricted an area, but in extensive areas there seems no doubt that over a long period of time the predator tends to improve the stamina and vigour of a species on which it preys. The larger, the more fleet and physically fit would on the average escape to reproduce, and the effects of overpopulation would be eliminated. It is the business of living under perilous wild conditions which tone an animal for successful existence, while, on the other hand, the existence of artificial or otherwise unnatural conditions, imperils a species.

Under the prevailing conditions at Long Point larger deer could perhaps be most successfully maintained by keeping the population to an optimum of numbers compatible with food supply. A regulation which called for shooting of the smaller adults and the occasional introduction of large, wild specimens from elsewhere, would improve the stock or aid in the maintenance of a superior size.

\section{LITERATURE CITED}

Charlevoix (Father). 1766. A voyage to North America: undertaken by the command of the present King of France. Vol. 2, Dublin.

Coyne, James H. 1902. Galinée's narrative and map; with an English version, including all the map-legends. Ont. Hist. Soc., Papers and Records, Vol. 4.

Giles, J. Bevans. 1880. Long Point. "The happy hunting ground". Forest and Stream and Rod and Gun, 15:26.

Landon, Monroe. 1931. Elk remains in Norfolk county. Can. FieldNat., 45:40.

Locke, Geo. H. 1917. Water colour drawings by William Pope. Public Library, Toronto.

[Ont. Game and Fisheries Dept.] 1910. Third annual report of the Game and Fisheries Department 1909, p. 13. Toronto.

Saunders, W. E. 1930. The destruction of birds at Long Point lighthouse, Ontario, on four nights in 1929. Auk, 47:507-511.

Snyder, L. L. 1928. Cryptotis parva, a new shrew for the Canadian list. Journ. Mamm., 10:79-80. 


\title{
A FAUNAL INVESTIGATION OF LONG POINT AND VICINITY, NORFOLK COUNTY, ONTARIO
}

\section{THE BIRDS OF LONG POINT AND VICINITY}

\author{
By L. L. SNyder
}

\section{Introduction AND ACKNOWLEDGMENTS}

The importance of Long Point and its vicinity as a station for ornithological investigation has been recognized by at least two ornithologists. Mr. W. E. Saunders, of London, Ontario, has visited Long Point and sections of the adjacent mainland on a number of occasions during the past twenty years and $\mathrm{Mr}$. W. E. Clyde Todd of the Carnegie Museum, Pittsburg, Pennsylvania, made a week's stay there in July, 1907, during which time he obtained an insight into the interesting character of the area. Information relative to the bird life observed by these men has been placed at the writer's disposal and appreciation of this aid is here gratefully acknowledged.

Being more particularly interested in the breeding or summer resident avifauna of Ontario, and due to the fact that other faunal investigations could be conducted after the spring season, our party did not journey to Long Point in 1927 until May 25. Becoming established in a camp on Second island on that day, work was commenced almost immediately and continued there until June 20. A change of camp from Second island to Courtright ridge was made on June 20, at which camp we remained until the summer's work was concluded on July 26. Nearly the whole of the point was reconnoitred by us during that summeron foot, by punt and by motor-boat. Some sections were worked repeatedly, while others were traversed but once.

It was evident during the early part of our visit in 1927 that the area deserved particular attention during a migration period and it was therefore planned that in May of the following year a party would again visit the point for the specific purpose of collecting migrating birds and observing migration in progress. Consequently our party of three arrived at Port Rowan on April 30, 1928. On the following day we were again established on Second island, remaining there until June 1.

During the summer of $1927 \mathrm{Mr}$. J. L. Baillie, Mr. John Edmonds and the writer were concerned with the bird work. Mr. Baillie's inval- 
uable help with the Museum's faunal surveys has been appreciated by the writer since 1924 and his work in the field at Long Point, as elsewhere, has contributed greatly toward such success as we have attained. His very complete field notes have been a valuable adjunct to those of the writer in the preparation of the following paper.

The thanks of the Museum, and of the writer personally, are especially due to $\mathrm{Mr}$. Edmonds who generously devoted his entire time and attention to the Museum's enterprise on Long Point during both expeditions. His interest and valued contributions to the survey have only heen rewarded by the satisfaction he must feel in having done useful and interesting work. In $1928 \mathrm{Mr}$. Edmonds, Mr. H. P. Stovell and the writer made up the party. The writer is indeed grateful to $\mathrm{Mr}$. Stovell for his assistance with the bird work in 1928.

After concluding the summer work in 1927 and the spring work in 1928 , it has happened that a considerable number of specimens from Long Point have come into the Museum's possession through Mr. Saunders, and from sportsmen, Mr. T. W. Jull, Mr. T. Wibby, and others, who hunt there in the autumn. A few specimens in the collection of Mr. J. H. Fleming and in the collection of this Museum have been discovered which were taken in the Long Point region at various times prior to our visits. In addition to the data furnished by specimens, and the Museum party's notes, many references from the valuable index to the literature on Ontario birds which is being compiled by Mr. J. L. Baillie have been discovered to pertain to the area. Also the collection of bird paintings by Wm. Pope who lived at Port Ryerse on the mainland has given us additional information, since they were executed there between the years 1840 and 1868, and doubtless were painted from locally taken specimens. The original paintings are now possessed by the Toronto reference library (Locke, 1917). However, it is realized that our work in the region, our subsequent fortune in getting additional specimens and data, and the inclusion of published records, does not bring the list to a state of completeness. It will be noticed by anyone familiar with the distribution of birds in southern Ontario that a few species which should occur at Long Point are omitted. There may be some which occur regularly, perhaps even commonly, but as a result of circumstances we have secured no information relative to them. It is suggested that Turkey Point on the mainland perhaps affords the best situation for continued work in the region, although the possibilities on Long Point are not exhausted.

I am particularly indebted to Mr. C. H. Ferris, of Port Rowan, for information relative to waterfowl which make Long Point a resort during their movements to and from their nesting grounds, and to $\mathrm{Mr}$. 
Lorne Brown, the present keeper of the Long Point lighthouse, who has directly and indirectly contributed much material and information.

In conclusion, I wish to acknowledge the assistance and advice of Mr. J. H. Fleming, obtained at various times during the prosecution of this work.

\section{Migration}

During our visit to Long Point in May, 1928, we arrived in time to see something of the assemblage of waterfowl which make the marshes and the waters of Long Point bay a resting resort during their movement to their nesting grounds. Although most of the flight had passed on, there was still a number of migrant species present, chiefly those which nest in the Canadian west. It would appear that these birds must follow a westerly or somewhat north-westerly course to the prairies. A more northerly route, at least in spring, is questionable since north Georgian bay and the Lake Superior regions cannot be shown to be on a main course of migration of prairie nesting waterfowl. Our camp on Second island was on the east side of the main marsh and during our stay we secured no evidence that ducks were passing over us in a northerly or easterly direction. Western ducks seem to detour from a Lake Huron route to feed in the Long Point marshes; they come in from and leave toward the west according to sportsmen.

Our best opportunity to view migration was with the shore and passerine birds. Long Point lies more or less in an east-west line paralleling the north shore of Long Point bay. Being situated on an island which lay in the path between the main forested body of the point and Ryerson's island, the latter in turn being on a direct line towards Turkey Point on the north mainland, many of the small birds which landed on Long Point from across Lake Erie to the south, or which reached the point by following around the shore from the west, naturally drifted past us towards the north shore. A feature which facilitated observations of transients on such an island was the presence of a narrow straight line of shrubs interspersed with a few trees, which extended north and south throughout its full length. This vegetation occupied the one prominent sand ridge which constituted the major portion of the island. With the beach and bay on the east side and the gradual submergence into marsh on the west the small birds were confined to a path past our door. Since the island was approximately only four hundred yards long it was possible to take a census of the area in a very short time. Most of the small birds seemed to work their way northward along the island while feeding. If disturbed, however, they were as apt to turn toward the direction from which they had come as to continue northward; in 
other words it was not possible to drive the birds off the north end of the island; their day migration could not be hastened.

Blackbirds (bobolinks, red-wings, grackles) were among the more conspicuous day migrants observed, but movements of flickers, redheaded woodpeckers, kingbirds, goldfinches and others were more or less markedly noticeable during the day. During the first two weeks of May, 1928, flickers passed our camp in considerable numbers and some were seen to take flight from Second island north to Ryerson's island. The same was true of the red-headed woodpecker which was most conspicuous during the end of the first week and the beginning of the second week of May. They also were noted leaving the island and flying north, and on one or two occasions individuals were seen coming to the island from the south. Our frequent checking of the bird population of the island indicated that many other species arrived and departed during the day. For the most part these flights were a drifting of individuals or small straggling groups. Night, of course, always brought the greatest change of bird life.

A feature which was brought to our attention in regard to the day movement of birds was the importance of winds as a check on migration. Although the weather might be otherwise fair, a strong wind would retard the gradual shifting of migrants from one place to another. On a few occasions, some conspicuous bird, such as the red-headed woodpecker, was seen to leave the island against a strong wind, and after making poor headway over the open stretch of water, return to land.

Generally speaking there were two waves as regards the number of species and individuals during the month of May, 1928. The first reached a peak at the end of the first week and the second about the end of the third week. The first might be described as the sparrow and miscellaneous wave, and the second as the shore-bird and warbler wave. Our records show minor drops in the curve which were due to daily weather conditions or to our daily procedure. Irregularity in the case of the latter was unavoidable since we were primarily paying attention to collecting and preserving specimens.

Some of the outstanding records concerning the individual numbers of certain of the smaller birds noted during May, 1928, may be mentioned although it is realized that one period of observation cannot be used to characterize Long Point as a migratory route. The least flycatcher was extremely common during the third week of May although it was known from our work during the previous year to have been virtually absent in summer. The willow shrubs along the shore of Second island harboured great numbers of them during the period between May 17 and 22 . White-crowned sparrows were common in mid-May and on the 15 th the 
species was indicated on our chart as "very common", a numerical designation rarely used by us in expressing the daily abundance of a species. Two other species noted in unusual numbers for their kind, within the experience of the writer, were the Lincoln's sparrow and the orange-crowned warbler. Twenty of the former were positively identified between May 17 and 22 and eight of the latter were noted between May 20 and 27. Perhaps the most outstanding observation of unusual numbers of an expected species was in connection with the brown creeper. It was seen regularly during the first two weeks of May but on May 3 it was a "common" bird, being seen in great numbers as it passed up Second island, and could be found scattered throughout the woods of Ryerson's island.

A note of interest in regard to the spring movements of certain marsh-breeding birds which we had found established in restricted sections of the marsh during 1927 may be noted. The black tern, Florida gallinule, long-billed marsh wren, and even the red-winged blackbird were found not to return immediately, at least in numbers, to the precise section of the marsh in which they were known to have nested the previous year. Representatives of some of the species were first noted to be scattered here and there, frequently at some distance from the area of summer concentration, but as the nesting season approached they appeared gradually to converge upon it. By the end of May, 1928, it was apparent that their interest again centred on the same small section of the marsh in which they had nested during the previous year.

Long Point is unquestionably an important station on the itinerary of many migrating shore-birds in spring. Representatives of various transient species first appear in April and the flight of these transients continues until past mid-June, there being of course some irregularity of numbers from day to day and also a perceptible diminution after the first days of June. Each of the species, found by us to be fairly common, requires a rather protracted period to pass. The dates of arrival and departure vary with the species but there is however, a concentration of numbers both of species and of individuals between May 12 and June 3. In 1927 the last northward-moving shore-bird (the direction assumed from the subsequent gap on our frequency chart) was recorded on June 18 , and in little more than two weeks (July 6 ) representatives of transient species reappeared on their way southward (the direction also assumed). By mid-July shore-birds were again present in some numbers but the flight, as is usual, was more gradual than in spring.

The migration of shore-birds was more easily observed during 1927 than in the following year. During the spring of 1927 the shore-bird flight passed up the beach of Second island, the extensive marshes not 
offering suitable feeding-grounds since the flats were covered with standing and flattened vegetation from the previous year's growth. This narrowing of their line of flight greatly facilitated regular observations of their movements. During the early part of the subsequent winter (on December 8, 1927) a severe storm on Lake Erie and in the Great Lakes region generally greatly affected conditions in the marsh. Heavy seas from the open lake overwashed the south beach of the point and raced through the marsh, scouring the mud-flats clean of their vegetation. In the following spring (1928) great areas of bare flats were exposed, bringing about a scattering of migrant waders. It was found that blinds and decoys were necessary to obtain and observe shorebirds. Food was apparently plentiful and many of the more strictly beach birds resorted to the mud-flats to feed.

The Long Point area is on the spring and autumn migratory route of great numbers of small birds. This is apparent from the records acquired through specimens which had been killed at the Long Point lighthouse, from reports from the keeper, from the observations of $\mathrm{Mr}$. W. E. Saunders and from our study of the region. Hosts of warblers, sparrows, thrushes, vireos and flycatchers pass over or along, or perhaps stop on and leave from the point each year. Our records show a total of seventy species which have been killed by the light. Most of these have been night-flying birds but a few species which fly by day have also been destroyed there, perhaps during daytime fogs. The light which has taken such a heavy toll of birds is considered the most destructive one in the Dominion. Perhaps to some degree this may be attributed to the type of light, a revolving white light, but from a study of the statistics of other lights (Lewis, 1927b) it would appear that the geographic location, and perhaps to some extent the immediate physiographic location, accounts for its destructiveness. Although the light, so far as is known, takes the heaviest toll of bird-life in the autumn, there is also a heavy mortality of spring migrants. The relative abundance of the various species of night-flying, spring migrants is fairly accurately revealed by the figures of destruction. This statement is based on a comparison of these figures with the records of abundance obtained by the Museum parties in 1927 and 1928. The following figures from available records show the destructions within recent years: during one night (about May 14) in the spring of 1925, 378 individuals of 30 species were picked up at the base of the lighthouse (Lewis, loc. cit.); on the night of May 17, 1928, about three hundred small birds struck the lighthouse (communication from Mr. Lorne Brown, present keeper of the light); on May 19, 1926, 169 birds of 28 species killed there were identified by Mr. W. E. Saunders (personal notes of W. E. S.); on September 7 and 9, 1929, 823 individuals of 37 species were killed, 
654 on the 7th (Saunders, 1930); between September 24 and 29, 1929, 1237 individuals of 49 species were destroyed (Saunders, loc. cit.); and between April 17th and 22nd, 1930, 269 individuals of 21 species were killed by the light (communication from Mr. Lorne Brown). As far as can be ascertained the heaviest destructions occur on cloudy nights, and according to the former light keeper, Mr. S. B. Cook, who had been stationed there for thirty years, there is a small but regular destruction going on throughout the migratory seasons.

There is some reason for believing that many birds appear on Long Point in the autumn as a result of being pocketed by the peninsula during a westerly movement along the north shore of Lake Erie. Townson (1928) has noted a westerly movement of day-flying birds in October, 1927, near the base of the point on the bay side. Also, Mr. James Savage has related to the writer that he observed a remarkable flight of flickers moving westward over the marsh at the base of Long Point on September 30, 1930. Observations made by Mr. Angus Buchanan on the robin have indicated a like movement in that species. Saunders (loc. cit.) states that sharp-shinned and other hawks were seen moving to the end of the point and then returning. He also states that swallows were flying westward along the point but attributed their direction to a westerly wind which was blowing. It is possible that many day-flying birds skirt Lake Erie or at least pass westward along its shore in the fall to cross the lake, perhaps at Point Pelee. On the other hand, it would seem that the night-flying species which strike Long Point light are birds attempting to make a direct crossing of Lake Erie at this point.

The most outstanding feature of the autumn migration at Long Point is the great aggregation of migrating water-fowl which assembles there. Since the earliest times the area has been noted as an ideal place for duck-shooting. As long ago as 1841 , before the time of modern firearms, it is recorded (Godley, 1844) that four men shot 750 ducks in twelve days during the month of October. Later, on October 2, 1876, five men bagged 646 ducks there in a single day (Hallock, 1876). An editorial in Forest and Stream (1883) states that a member of the Long Point Company averaged 51 ducks per day for eleven days and another 61 ducks per day for nine days. Even with the general reduction in the numbers of ducks throughout North America, Long Point still retains a reputation as one of the best situations for duck-shooting in the whole Dominion. The writer regrets to state that he has been unable to obtain access to the important work on ducks by Phillips (1922) in which there is doubtless considerable information relative to the Long Point region. 
Ducks from the north and northeast, such as the black duck, golden eye, etc., constitute a large percentage of the autumn flight, but there is a heavy influx of prairie nesting species. Many of these water-fowl appear to come from the west as previously remarked. Sportsmen have observed their flights coming in to the marshes from the west, following along the north shore of Lake Erie.

The lack of opportunity to investigate the movements of birds in much detail, for extended periods over several years, has made it impossible to present more than the major features of Long Point as a migratory station. It is in regard to migration that subsequent workers will be able to add information which will bring our knowledge of this area to a state adequate for comparison with the other Lake Erie stations such as Point Pelee and Presque isle which have been so well investigated.

\section{Annotated List}

The following list includes 230 species of birds which are, or have been, resident, transient, or of accidental occurrence on Long Point or in its vicinity. Twenty-two additional species for which we have but vague or questionable information, but which seem to be of probable occurrence, and species known to occur in close proximity to the area considered, but not definitely within the area, are appended as a hypothetical list. There are 169 species represented in the collection of 783 specimens from the area now in the Museum's collection. Most of the specimens were collected during June and July, 1927, and May, 1928 , but a number have been preserved from birds picked up at the lighthouse, from sportsmen's bags, and from a few miscellaneous sources. A catalogue of all specimens from this area now in the Museum's possession is included in the text. Specimens in the catalogue are adult unless otherwise stated. The sex of each has been indicated according to findings by dissection. In the case of a large number of specimens which were destroyed at the lighthouse in the fall, internal disintegration made it impossible to determine the sex. Although in many cases the sex appears to be obvious from the type of plumage, it has been considered best to mark them as, sex "?".

The arrangement of the list is in accordance with the 1910 edition of the American Ornithologists' Union Check-List, and the nomenclature used conforms with the A.O.U. list with such changes as have been published in the supplements that have appeared in the Auk.

The inclusion of species other than those authenticated by specimens has been done as carefully as possible. Some such records are based on our own observations made under favourable conditions and others are from the literature. In the latter case, the accuracy of the statement 
regarding a particular species has been considered in the light of information relative to that species for the general region, and with due consideration of the ability of the observer.

Colymbus auritus. Horned Grebe.-A common spring and fall migrant. As many as thirty individuals were noted on April 30 during a short trip which we made along the shore of inner Long Point bay near Port Rowan. It remains about the open waters of the marsh and bay until the second week in May, the last, apparently a mated pair, having been seen on May 9, 1928.

$$
\text { 우 May 2, } 1928 .
$$

Podilymbus podiceps. Pied-BILled Grebe.-This grebe is a summer resident species, found sparingly throughout the main marsh. A nest containing eight incubated eggs was collected on June 9, 1927. The nest, a mass of dead, water-soaked reeds, was situated on floating vegetation at the edge of a reed-bed near a small neck of open water in the marsh.

In mid-May, concealed and protected from the cold wind by a grassblind on the mud-flats, the writer frequently heard the song of this species, close at hand and from far across the extensive marsh. Sometimes their usual rail-like song was concluded by three pleasing notes given in an ascending phrase, often repeated many times. This part of the song is especially suggestive of contentment and has the effect of being given in a minor key.

This species, a night-flying migrant, is subject to the lure of the Long Point light as attested by a specimen now in the R.O.M.Z. collection, which struck the light on September 7, 1929. Five others were killed by the light in April, 1930 (between 17th and 22nd) and another which struck the light between September 24 and 29, 1929, has been recorded by Saunders (1930).

우 June 9, 1927, Im. ? September 7, 1929.

Gavia immer. Loon.-The fishermen state that the loon formerly nested on some of the islands of the marsh but no nests have been noted in recent years. The species may still nest in the area as it was present throughout the summer of 1927 , from one to three having been noted at irregular intervals. On May 29, 1928, a flock of fourteen loons was seen off-shore from Second island in outer Long Point bay. Nine or ten of these birds were still largely in winter, or immature, plumage, their heads and necks showing some of the dark green glossed feathers of the second or adult nuptial plumage. These birds were probably the last northward-moving individuals. The only specimen in the Museum's collection from Long Point is an interesting bird in the first winter plumage. It is small in all its measurements which are as follows: 
length, $731 \mathrm{~mm}$.; wing, $310 \mathrm{~mm}$.; tail, $75 \mathrm{~mm}$.; culmen, $68 \mathrm{~mm}$.; depth of bill at base, $19.5 \mathrm{~mm}$; tarsus, $67 \mathrm{~mm}$.; outer toe and claw, $108 \mathrm{~mm}$. It would seem that this specimen is well within the proposed race, G.i. elesson of Bishop (1921). Another peculiarity of this specimen is in the sharp angle of the gonys, a condition which can only in part be attributed to shrinkage in drying. There is, however, no doubt of the specific identity of the specimen.

\section{Im. \&. November 12, 1930.}

Gavia stellata. Red-Throated Loon.-Mr. Lorne Brown, the present keeper of the Long Point light, has reported that one was killed by the light on April 17, 1930. Also a specimen in the R.O.M.Z. collection was taken at Vittoria, Norfolk county, a locality outside the "vicinity" of Long Point but adjacent to it. Wm. Pope has figured a young specimen of this species (Locke, 1917) which was in all probability taken near Port Ryerse. The picture is dated November, 1867. The species probably appears fairly regularly as a rare transient on Long Point bay.

Uria lomvia lomvia. BRUNNICH'S MURRE.-This species has occurred in the region during its irregular visits to the lower Great Lakes region. The writer has seen a specimen, in a collection of mounted birds owned by Mr. Wm. Smith of Port Rowan, which was taken locally about 1896 .

Stercorarius parasiticus. PARAsitic JAEger.-A rare fall and winter visitant. A specimen taken at Port Rowan at some time prior to 1906 is now No. 10,568 in the collection of Mr. J. H. Fleming. Another, a mounted, immature specimen, has been seen by the writer in the collection of Mr. Wm. Smith of Port Rowan. This specimen was collected locally about 1900. A third specimen now in the Museum's collection, was killed at the Long Point light on the night of September 2, 1930 .

Im. の゙ September 2, 1930.

Larus hyperboreus. Glaucous Gull.-Probably an occasional visitant to the region in fall and winter but the only record for the species is that of Townson (1928), which refers to one seen by him on October 23, 1927.

Larus marinus. Great Black-BACKed Gull.-Apparently an uncommon winter visitant to the area. A mounted adult in the collection of $\mathrm{Mr}$. Wm. Smith of Port Rowan is the only specimen from the region seen by the writer. Local hunters, however, have told me they have seen this large, dark-backed gull in late fall.

Larus argentatus. HERRING GULL.--Small roaming flocks, and individuals exhibiting a great variety of stages of plumage immaturity are to be found throughout the summer about outer Long Point bay. 
Adult birds apparently are not to be found there in summer; they leave in the spring and return in the fall. The summering birds seem to depend on the waste from fisheries for food. The greatest number seen at one time, approximately one hundred and twenty-five birds, was congregated about the pound nets near Gravelly bay on July 19, 1927. So far as we have been able to discover, herring gulls do not nest on Lake Erie.

Colour sketches of the bills of six immature specimens, all collected from the same flock on July 19, 1927, show a gradation from the dark bill to nearly a yellow, orange-spotted condition. Comparison of the specimens does not show a corresponding gradation of plumage.

2 Im. ơ's July 19, $1927 \quad 4$ Im. ㅇ's July 19, 1927.

Larus delawarensis. RiNG-BILled Gull.-Fairly common in spring, immatures remaining until well into the summer. The latest record we secured was that of an individual noted on June 23, 1927. Although we have no definite information, this gull probably reappears in some numbers in the fall after mid-October.

A specimen of gull collected by Mr. J. L. Baillie on June 4, 1927, from a flock of ring-bills is of particular interest. It is for the most part in badly worn immature plumage. A brief description of this specimen is as follows:- head, neck and underparts white, the undertail coverts with a few pale brown spots distally; back, including scapulars, pale blue grey; upper tail coverts white; alulae and distal primaries faded fuscous black; proximal primaries, secondaries and tertials with fuscous brown forming a terminal wing band; greater and median wing coverts largely dirty white, the lesser coverts faded pale brown; tail, white, the terminal fourth faded fuscous and the remainder of the terminal half slightly mottled with that colour. It will be seen from the following statement of dimensions that this specimen is small for Larus delawarensis: length, $456 \mathrm{~mm}$.; tail, $131 \mathrm{~mm}$.; wing, $338 \mathrm{~mm}$.; culmen, $39 \mathrm{~mm}$.; depth of bill at base, $15 \mathrm{~mm}$.; tarsus, $54 \mathrm{~mm}$.; middle toe with claw, $44 \mathrm{~mm}$. A comparison of the skin with available material indicates that, except for the improbability of the occurrence, the specimen might be referred to Larus canus of Europe. The range of size and colour of immatures of Larus delawarensis, however, probably includes individuals similar to this specimen although material available for comparison has not demonstrated this point.

Im. $\sigma^{7}$ May 13, 1928. Im. ㅇ June 4, 1927.

Larus philadelphia. BONAPARTE's GulL.-Noted regularly during both of our visits to Long Point, either as scattered individuals or in flocks. As many as eighty-five were seen on one day (July 6, 1927), while forty and fifty were frequently noted. Mr. W. E. Saunders has noted them at Turkey Point on visits there in spring. The species seemed to invade the region in greatest numbers about May 23, 1928. 
There is a rather wide range of variation in the plumage of the immature birds seen and collected. As late as July 12, an immature specimen was taken with a nearly white head, while an immature bird with more than fifty per cent. of the head showing new, dark feathers, was collected as early as May 7. The extent of the dusky pattern on the wing coverts of immatures is also greatly variable but even those having this area almost completely erased by feather renewal and fading have the characteristic tail band and primary pattern of immaturity. The three adults collected are all completely dark-headed birds. Although few of these non-breeding adults were noted, it is of interest that some do summer in the Lake Erie region. Transient birds from their northern breeding grounds probably appear in the Long Point region after midOctober.

$$
\begin{aligned}
& \text { ㅇ May 8, } 1928 . \\
& \text { Im. O } \sigma^{7} \text { May 26, } 1927 . \\
& \text { “ ठ May 29, } 1927 . \\
& \text { " व May 31, } 1928 . \\
& \text { “. \& June 4, } 1927 . \\
& \text { “ 우 June 4, } 1927 . \\
& \text { “ वै June 7, } 1927 .
\end{aligned}
$$

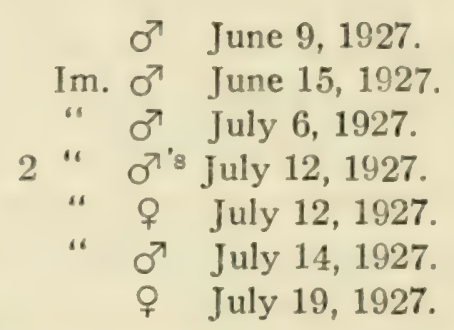

Sterna caspia imperator. Coues' Caspian Tern.-Transient individuals were fairly common in early May, 1928, but by the second week their numbers were reduced. From one to four of these birds were seen every few days throughout the summer of 1927. A female specimen collected on June 23, 1927, had been banded as a young bird at Gravelly island (Lake Michigan), by Wm. I. Lyon, on July 21, 1925 (Nat'l Parks of Can. 1928). This bird which was approximately two years old, and another bird taken in July, are virtually adult in plumage although both possess a slight sprinkling of white-margined feathers in the black crown and also a few black-tipped white feathers along the upper margin of the gape and malar region. There are no known nesting colonies of this tern in the Lake Erie region and the birds noted by us in summer were unquestionably non-breeding individuals.

Im. \& June 23, 1927. Im. ㅇ July 18, 1927.

Sterna hirundo. Common Tern.-A common species during spring and summer. Local residents of the region know it by the name "gannet". It was first noted in 1928 on May 1, but it was not seen in numbers until May 4. According to Mr. W. E. Saunders, common terns nest on the south beach of Long Point about two miles west from the lighthouse. Mr. W. A. Gordon of Port Dover has informed the writer that the eggs of these birds are distributed so thickly on the south beach at this point as to make it difficult to walk through the colony without 
stepping on them. Young of the year, presumably from this colony, were first collected by us on July 17, 1927.

In a series of seven, presumably non-breeding birds in their second year, which was taken between June 19 and 23, a gradation of plumage change is demonstrated. The dark cubital border of the wing changes almost to obscurity from the earliest taken specimen to the latest. Moult, wear and fading are factors in the loss of this pattern. The crowns exhibit a gradual darkening, the white foreheads being encroached upon posteriorly by the growth of new feathers. The two outer primaries in each wing of a bird taken on June 19 are old, while the next bird in the series (taken June 23) has but one worn outer primary, the other having been dropped. In the remainder, primary replacement is complete. One of these non-breeding birds is unique to the whole series, adults and immature alike, in having a tail $183 \mathrm{~mm}$. in length, $14 \mathrm{~mm}$. longer than any other in the collection. The underparts of these immature birds are, for the most part, clear white. Such features as the long tail and clear white underparts on these near-adult common terns make uncertain the use of these characters as field marks for Forster's tern. Birds in this particular phase of plumage were not uncommon in flocks of typically adult common terns, at Long Point, especially in late summer. The age of one of these birds is fairly exactly known. It was collected on June 19, 1927, and carried a band which was placed on it when it was a nestling on July 17, 1926, at Lone Tree island, Huron county, Michigan, by Walter E. Hastings (Nat'l Parks of Can., 1928).

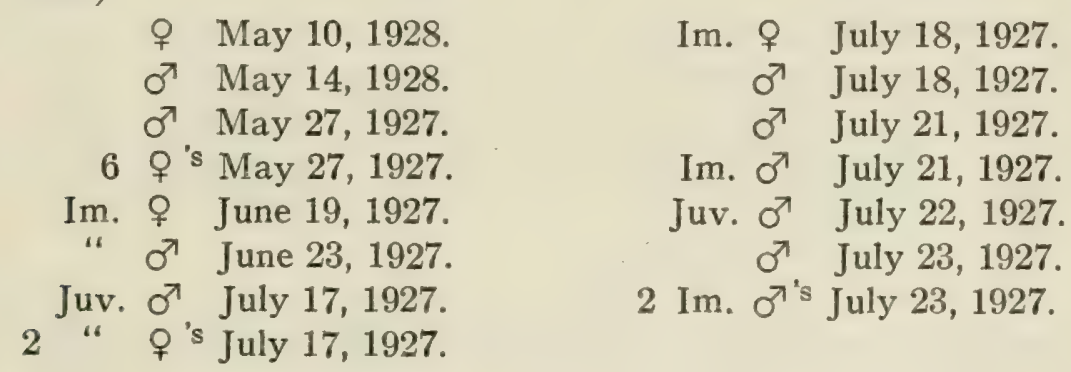

Chlidonias nigra surinamensis. BLACK TERN.-Local residents refer to this species as "black gannets". First noted in 1928 on May 3, but it was not common until May 13. Although wandering black terns were met with in all sections of the marsh and about the bay, the areas in which they were particularly attached for nesting were surprisingly restricted. Three colony sites were found by us in 1927, one on the marsh side of Second island and two on the marsh side of Ryerson's island. The closest attention was given to the Second island colony which consisted of from fifteen to twenty pairs. Their chosen area comprised approximately one acre. Nests were placed in open situations 
near and among growing reeds on low, floating masses of dead vegetation which was subject to the rise and fall of the ever changing water level of the marsh. One nest found was placed on the upturned bottom of a water-logged fish-box. The nests were for the most part composed of dead reeds like the mass on which the birds nested and could scarcely be visualized as a distinct addition to the mass, but rather they appeared to be a rough form made from the materials at hand.

The first set of eggs, containing two, which may have been a complete clutch, was found on May 30. The usual number of eggs in a nest was three, although a few contained but two, while one nest found contained four eggs. All sets appeared to be complete by the end of the first week of June in 1927. The usual variations in the size, colour and pattern of the eggs of this species were noted.

One of the most annoying experiences of our work on Long Point was our inability to secure downy young of this species although we made special efforts at the time the eggs were hatching (between June 17 and 23). All nests under observation were empty on June 28. There is probably a considerable variation in the dates of nesting from year to year. Mr. W. E. Clyde Todd records in his notes of July 12, 1907, while visiting the Long Point marshes, that on that date he examined several of their nests which held three eggs apiece. They were heavily incubated at this late date. He suspected young, but did not see them. The reed-beds were carefully searched by us in an attempt to locate the birds in the downy plumage, but they were completely successful in evading us. Our first proof that the young had actually been reared in the colony was when two, fully-fledged, were collected on July 11. At this stage the birds were prone to take wing and could be seen swimming like ducks into the sheltering reed-beds. Specimens with sparse down attached to the feathers of the heads are the nearest we came to collecting downy young of the year.

A specimen taken on July 6,1927 , is of interest. The white plumage of the underparts, especially about the neck and throat, is apparently being replaced with new white feathers. The mantle and tail are very much abraded and discoloured, but the primaries, except the outer left one, are new, the outer right is missing. This bird is apparently a young of the previous year which is passing from the first winter plumage to the adult winter plumage, not having attained any of the black feathers on the head or ventral surface characteristic of most birds in their second summer.

In the series of seventeen adults collected, a gradation in the initial stages of the change from summer to winter plumage is shown. The first specimens which possessed a few white feathers in the loral region and about the gape were taken on June 28 . In a specimen taken on 
July 23 the forehead is white, the crown grey and the lores, malar region and throat almost entirely white. A few new white feathers are also to be found on the breast. The moult progresses in a remarkably uniform way as shown by the series of specimens. When arranged according to date, the plumage change about the head and neck is almost precisely graded.

In connection with the courtship of this species, one or two observations are worthy of note. On May 25, 1928, while concealed in a shooting blind on the mud-flat, I had an opportunity to watch a mated pair of black terns for some time. Twice I saw the male feed the female with small fish which he brought from the bay. She accepted them in the helpless manner of a young bird and waited patiently on the flat during the interval between the two feedings. After the second offering the male sat on her back for a time but did not attempt to copulate. Further observations on the species at this season indicated that it was a habit for the males to feed the females just prior to the height of nuptial activities. Many terns (presumably males) were seen conveying small fishes from the bay to the particular section of the marsh near where the colony had nested the previous year. Our observations throughout the previous summer, however, indicated that the food of this tern is largely insects during the nesting season.

\begin{tabular}{|c|c|c|c|}
\hline $0^{7}$ & May 13,1928 & 우 & July 12,1927 . \\
\hline $0^{7}$ & May 23,1928 & Juv. $\sigma^{7}$ & July 12,1927 . \\
\hline & May 26, 1927. & 우 & July 14,1927 . \\
\hline & May 26, 1927. & 3 \% & July $18,1927$. \\
\hline$\sigma^{7}$ & June 28, 1927. & Juv. 우 & July $18,1927$. \\
\hline 3 우 & June $28,1927$. & " & July $21,1927$. \\
\hline n. $ᄋ$. & July $6,1927$. & 2 우 's & July 22,1927 . \\
\hline 2 \%'s & Ju!y 11, 1927. & Juv. ণొ & July $22,1927$. \\
\hline $\begin{array}{l}\text { Juv. } 0^{7} \\
0\end{array}$ & $\begin{array}{l}\text { July } 11,1927 . \\
\text { July } 11.1927\end{array}$ & 오 & July 23,192 \\
\hline
\end{tabular}

Phalacrocorax auritus auritus. DOUBLE-CRESTED CoRMORANT. - This species was described to us by local sportsmen as being occasionally seen in the late fall, but it was not until the fall of 1930 that we were able to substantiate their claims. A female now in the Museum's collection was secured and presented by Mr. T. W. Jull of Toronto. There is an undated picture of this species in immature plumage in the Pope collection (Locke, 1917) of paintings. The subject was probably a bird taken near Port Ryerse.

$$
\text { ㅇ October 20, } 1930
$$

Mergus americanus. Merganser.-A spring and fall migrant, apparently not uncommon. None was seen during our stay on the point in May, 1928, the species apparently leaving for its nesting grounds at 
an carlier date than the red-breasted merganser. It is apparently not a summer resident, although Mr. IV. E. Saunders saw two on June 7 or 8 , 1925, in the vicinity of Long Point. Mr. Hanson Ferris states that its appearance in spring and departure in the fall are regulated somewhat by the season's thaw and freeze-up on Long Point bay.

ㅇ November 12, 1930

Mergus serrator. Red-Breasted Merganser.-A spring and fall migrant. Large flocks of these birds, some estimated to be composed of two hundred and fifty individuals, were occasionally noted in the bay in May, 1928. They were last noted on May 18, when a large open raft of these ducks passed our camp some two hundred yards off shore. As they moved along, the males were displaying to the females in great earnest, as many as six males appearing to solicit attention from an individual female. They would swim in circles around her, stretching their necks forward and backward, occasionally picking at her and frequently causing a great splashing of water in their wake. Their courtship was without vocal utterance so far as we could detect from shore.

Im. ㅇ about November 9, 1929

Lophodytes cucullatus. Hooded Merganser. Fairly numerous as a spring and fall migrant. In spring it appears late in March remaining until near the end of April. According to Mr. Ferris it does not appear in any numbers in the fall until after the middle of October, remaining until well into November.

ㅇ about November 9, 1929

Anas platyrhynchos. Mallard.-An early spring migrant to be expected after the middle of March. It remains until late in April although most of the birds have passed on toward their nesting grounds before that date. We saw six birds on April 30, 1928. Individual males were seen on two occasions during the summer of 1927 , but the species is apparently a rare summer resident. Giles (1880) mentions this species as breeding in the marshes of Long Point. Although considerable numbers of mallards are secured in the late fall, the species is not as abundant as the black duck. McIlwraith states (1886) that "it assembles in vast flocks [at Long Point] in the fall to feed on the wild rice." At least two specimens banded at Lake Scugog, Ontario, have been taken at Long Point by sportsmen (Lincoln, 1922).

Anas rubripes. Black Duck.--One of the most abundant ducks frequenting the region as a migrant; a common summer resident also. It arrives about the middle of March and transient individuals remain until well into April. 
Many birds summer in the marshes of Long Point and the species is the most common nesting duck of the area. During the last week of May, 1928, flocks of approximately fifty black ducks were seen well back in the marsh in the more open water of the larger ponds. These were probably males which had congregated after mating, while the females were on their nests. Flocks were not seen, however, in June or July, the birds apparently scattering and concealing themselves during their moult.

Four nests were found during our visits to the point. In all cases the nests were built in fairly dry situations on islands in or at the edge of the marsh, usually several yards from water. Standing or fallen trees and grass tufts formed an immediate protection to the nests found. Down was used as a nest-lining in all these examples and rather fine grasses and sedges formed the bulk of the structure. The numbers of eggs in three completed clutches found were nine, nine and ten respectively. Eggs from a nest collected on May 31, 1927, contained well formed embryos.

Black ducks from the north appear in the marsh early in September, the species being present in numbers until late in November. Many ducks of this species shot at Long Point were birds banded at Lake Scugog, Ontario, as noted in the official Canadian Record of Bird Banding returns (see Can. Field Nat., 1924 to 1930). Several presumed hybrids between this species and the mallard taken at Long Point have been recorded by Fuertes (1916).

$$
\text { 우 } \operatorname{May} 31,1927
$$

Chaulelasmus streperus. GadWALL.-A rare duck in spring, but a few occur in the late fall. A mounted pair taken locally is in the collection of Mr. Wm. Smith of Port Rowan. Wm. Pope (Locke, 1917) has figured a female which was probably taken near Port Ryerse.

Mareca penelope. European Widgeon.-Fuertes (1916) has recorded the taking of a specimen of this duck at Long Point. It is now in the collection of the Long Point Company at "The Cottages".

Mareca americana. BALDPATE.-Apparently rare in the spring but a few appear regularly in the fall. Present in September and October, usually departing for the south by the end of October, but we have two November specimens in the Museum's collection. A hybrid of this species and the mallard has been recorded from Long Point by Bigelow (1907).

$2 \sigma^{7}$ 's November 21, 1906

Nettion carolinense. Green-winged Teal.-A regular late March and April migrant; it returns to the marshes in September usually 
after the flight of blue-winged teal has passed and remains until well into November. About as numerous as the blue-winged teal at Long Point. ơ about November 9, 1929

Querquedula discors. BLue-winged TEAL.--Not abundant, but appears regularly in April and early May and in September. It is said (Giles, 1880) that this species formerly bred in the Long Point marshes. We secured no evidence that it does so at the present time, but Mr. Ferris states that it occasionally does. One hundred and ten were counted by us near Port Rowan on April 30, 1928, and a pair, the latest occurrence according to our records, was seen on May 17 of the same year.

Spatula clypeata. Shoveller.-Rather rare; a few appear at Long Point each spring and fall. A male was seen by us on April 30, 1928, near Port Rowan, and a mounted male is in the collection of $\mathrm{Mr}$. Wm. Smith at Port Rowan. A painting of a female specimen which was probably secured in the region is in the Wm. Pope collection (Locke, 1917).

Dafila acuta tzitzihoa. American Pintail.-A regular and fairly common migrant in the spring after mid-March, mostly in April, remaining until early in May, our latest record being May 6, 1928. In the fall numbers of them occur in the marsh, coming in after the first of September, becoming most common in October and disappearing about the end of November. Mr. J. H. Fleming has given the writer an account of a curious duck shot by Mr. C. K. Rogers near Port Dover (perhaps within the area here considered) in the fall of 1911. The duck was forwarded to Spanner's taxidermy establishment at Toronto on November 11, 1911, and a consideration of its peculiarities has led Mr. Fleming to believe it to be a hybrid between the pintail and mallard. $\sigma^{7}$ about November 9, 1929

Aix sponsa. Wood Duck.-This beautiful summer resident duck finds Long Point particularly suitable as a breeding ground since the wooded ridges afford the necessary hollow stubs for nesting and quiet lagoons are near at hand. Although wood ducks are not numerous in summer we saw them regularly and several broods were brought out near our camps. Males were still consorting with females on May 16 in 1928. Although the males probably remained about the marshes none was seen during our summer stay in 1927 . The earliest appearance of nestlings was noted on June 21, 1927. The local population of this duck is augmented by birds from elsewhere in southern Ontario in the fall.

$$
\begin{aligned}
& 2 \text { 어's May 15, } 1929 \\
& \text { 우 June 21, } 1927 \\
& \text { Nestling ơ June 21, } 1927
\end{aligned}
$$


Marila americana. ReDHEAD.-According to Townson (1928) the redhead is not as common at Long Point as it was thirty years ago. However, numbers visit the point for a short time in late March and early April, and again, perhaps in greater numbers, during October and early in November, the middle of the autumn being the time of greatest numbers.

Marila valisneria. CANVAS-BACK.-The dates of spring and fall occurrence of this species are apparently about the same as those for the redhead, except that the canvas-back is more inclined to remain later in the fall. Townson (1928) states that this duck was very scarce at Long Point thirty years ago while now thousands of them visit there each fall. Only a small percentage of these ducks are subjected to hunters' fire since they feed extensively in the open waters of the shallow inner bay.

$\sigma^{7}$ about November 9, 1929

Marila marila. SCAUP DUCK.-A common species arriving in early March and remaining until toward the end of April, returning in October and staying until December. Like the next, this species is not as abundant as formerly but it is still well represented in the annual fall bags of sportsmen.

Marila affinis. Lesser SCAup Duck.-This duck arrives toward the end of March and usually stays somewhat later in that season than the preceding. We saw them as late as May 30 during 1927 and 1928. These late birds are usually paired before they leave and it is possible that an occasional pair remains in the Long Point marshes to nest, but as to this we have no certain evidence. In the fall they return in September and remain until well into November. The lesser scaup is a common migrant but its numbers at Long Point are not as great as they were some years ago.

$$
3 \text { o' } \text { 's May 2, } 1928 \quad \text { \% May 2, } 1928
$$

Marila collaris. RiNG-NECKED DUCK.-A regular spring migrant, in April, but not so numerous in spring as in the fall when it is plentiful during October and well into November. The species is known at Long Point, as elsewhere, as the marsh bluebill. Wm. Pope (Locke, 1917) had illustrated this species and this particular piece is dated April 17, 1843.

$$
\sigma^{\top} \text { about May 9, } 1929
$$

Glaucionetta clangula americana. GoLDEn-Eye.-An open water duck appearing in March fand remaining until early May, our latest date being May 1, 1928. It appears in numbers in November, remaining well into December. 
Charitonetta albeola. Burfle-IEAD.-A plentiful early spring migrant remaining until May and returning after the middle of October (Townson (1928) noted the first in the fall of 1927 on October 24) when it is present in numbers in the open water until well into November. ๙ May 2, 1928

Clangula hyemalis. OLD-SQuAw. - This species arrives from the north in the fall, usually about the first of November, and is present in the bay until ice drives it to open water. In spring it appears again with the opening of the bay and is present in numbers until May. The latest record obtained by us was a fresh specimen picked up from the beach where it had drifted, probably after being freed from the nets off-shore by fishermen. This was on May 15, 1928. Knowing the lifting days of the fishermen and considering the condition of the bird we estimated that it was caught only a few days previously.

Many of these birds are accidentally caught in the gill nets set in the bay. One specimen which we secured was taken from a net set in 25 feet of water but these birds are caught in depths many times greater than this example according to fishermen.

$$
0^{7} \text { about May 11, } 1928 \text { 우 about May 13, } 1928
$$

Somateria spectabilis. KING EIDER.-Little can be ascertained as to the numbers of king eiders which visit this section of Lake Erie in the late fall, but that they do occur is substantiated by two specimens taken locally and seen by the writer in the collection of mounted birds owned by Mr. Wm. Smith of Port Rowan.

Oidemia deglandi. White-Winged Scoter.-A fairly numerous bay duck in the late fall and from early spring until mid-May. Like the old squaw this scoter is regularly taken in gill nets set in the bay.

$$
\begin{array}{ll}
\sigma^{7} \text { about May 9, } 1928 & \text { क about May 23, } 1928 \\
\text { के about May 12,1928 } &
\end{array}
$$

Oidemia perspicillata. SURF SCOTER.-This scoter is not common and certainly not well known to local sportsmen although it probably occurs regularly in the open lake during late fall and in the spring. An adult male specimen secured by us at rather a late date, May 29, was probably caught in fishermen's gill nets a few days previously. 万" about May 27, 1927

Erismatura jamaicensis. Ruddy Duck.-An April and October migrant, not as common as it was several years ago, but occurring regularly in some numbers. These little ducks, like the buffle-head, are locally known to sportsmen as "Butterballs". Two males in changing plumage taken locally were noted in the collection of Mr. Wm. Smith of Port Rowan, but the majority of specimens taken by hunters are said to be in the grey, immature plumage. A ruddy duck struck the Long Point light on April 21 or 22, 1930, according to Mr. Lorne Brown, the keeper. 
Chen hyperboreus hyperboreus. SNow Goose.-This goose occasionally appears about the marshes of Long Point in the fall. A mounted specimen taken locally was seen by the writer in the collection of Mr. Wm. Smith at Port Rowan and local sportsmen have informed the writer that small flocks sometimes settle in the marshes to feed.

Chen cærulescens. Blue Goose.-Townson (1928) has recorded seeing a blue goose at Long Point on October 20, 1927. An adult female shot by Mr. J. R. Wells of Toronto on November 2, 1914, at Port Rowan has been recorded by Fleming and Lloyd (1920). So far as can be ascertained this goose is rare and of irregular occurrence in the region.

Branta canadensis canadensis. CANADA Goose.-A northward migrant in late March and early April, returning after mid-October. The Canada goose does not appear in very large numbers at Long Point but it is of regular occurrence, according to Mr. Ferris. Townson (1928) records seeing one there on October 16, 1927.

Branta canadensis hutchinsi. Hutchins's Goose.-The only record of this subspecies for the region has been made by Fleming (1906). The specimen which is in Mr. Fleming's collection was taken at Port Rowan on October 6, 1896.

Cygnus columbianus. Whistling Swan.-Occasionally seen in late March and early April on their way northward, and on their return during October. Early records indicate a similar status one hundred years ago (Need, 1838, and Small, 1866). An immature female taken at Turkey Point is in the Museum's mounted collection and a mounted female taken locally was seen by the writer in the collection of Wm. Smith of Port Rowan. Im. \& October 29, 1917.

Cygnus buccinator. Trumpeter Swan.-McIlwraith (1886 and 1894) states that he had "seen two which were killed at Long Point in Lake Erie." It is not likely that more recent records from this area have been or will be obtained, but since the probability of McIlwraith's record being correct is great, the writer has been inclined to accept it. There are specimens in collections which were collected, about the time implied by McIlwraith, in the general region of southern Ontario. A picture in the Pope collection (Locke, 1917) is of the trumpeter swan and Mr. J. H. Fleming states that there is no doubt about the identity. The illustration is dated April 6, 1847, and in all probability it is based on a locally taken specimen.

Botaurus lentiginosus. BiTTERN.-A common inhabitant of the marshes of both the point and the adjacent mainland. Several pairs nested near our camp on Second island and we had opportunity casually to observe the species from the season of mating until late in the summer. Nuptials occur in early May. At this time bitterns were 
particularly conspicuous because by day they frequently took to wing, and on quiet evenings the voices of these birds could be heard from the borders of the marsh near us and from far beyond where the distant reed-beds were rapidly being obscured by the fading light. During the day pairs would fly about in tangled circles, one bird pursuing another in close tandem. This was no doubt a mating performance.

The bittern is a remarkable example of the close blending of an animal with its environment; its colour, its voice and its behaviour appeal to one as being in perfect harmony with wet, rush-grown surroundings. The writer had opportunity on May 14, 1928, to observe what appeared to be the limit in the bittern's employment of the well known standing-reed ruse. The bird was first sighted at a distance of about fifty yards as it was cautiously stalking through rather low marsh vegetation. As if suddenly becoming aware of being observed it thrust its neck upward, assuming the characteristic bittern attitude of eyes front but bill skyward. Directing my course so that I would pass several feet from the bird and partially circle it, the bird was confronted with two difficulties. First, the vegetation was too short to lend the upright bird concealment from my close approach. Second, my circling course made it difficult for it to keep the streaked front of the neck toward me. As I proceeded the bird lowered its body by imperceptible degrees and in attempting to keep its front toward me it listed to one side. The bird depended on its attitude and concealing colour until I was within four or five feet of it, finally flushing with the expected awkward flapping of its wings and uttering its guttural "quawk". The unusual part of the observation, however, was that because the bird had been forced to twist its body and lower itself as I approached, it was finally lying on its side partially submerged in water. The bird's attention had been so strongly directed at me that it had soaked the feathers of one side, including its wing, in water, a performance it would no doubt have carefully avoided except in such an emergency.

In the Long Point region the eggs of the bittern hatch during the first two weeks of June. The young are in the nest or in the immediate vicinity of the nest for several weeks and newly hatched young are apparently well guarded by the parent bird. One instance noted in this connection was of a parent bird which clung to the nest until we were within arm's length of it. Our attention was originally directed to the bird when some distance away by the prolonged rattling growl produced by the parent when we were approaching.

The latest occurrence of the bittern in the fall at Long Point is October 14, 1928. This observation was made by Mr. James Savage and it concerned a partial albino bittern seen under good conditions for 
close observation. The bird possessed white secondaries on the left wing and white primaries and secondaries on the right wing.

$$
\begin{array}{cl}
\text { Nestling, क June 7, 1927. } & \text { क June } 8,1927 . \\
\text { " व June 8, 1927. } & \text { के July 15, } 1927 .
\end{array}
$$

Ixobrychus exilis. LEAST BITTERN.-Not as common or as generally distributed as the bittern. The earliest date on which the least bittern was seen by us was May 17, 1928. One struck the Long Point lighthouse on May 19, 1926. These dates suggest that they usually arrive about mid-May. A few nests were found in mid-June, 1927, near the border of the marsh off Second island. Some of these were situated in growths of cattail rushes and others were in reed-beds. All of the nests found were made of dry reeds or rushes such as were found near at hand and were secured to growing plants approximately one foot above the water. A nest collected on June 17, 1927, contained four fresh eggs.

Mr. James Savage has kindly given the writer an observation for record here which concerns the Cory's least bittern phase. On September 16, 1928, a Cory's bittern was seen in the Long Point marshes near the base of the point. The skill of the observer and the conditions under which the observation was made leave no doubt as to the accuracy of the record.

$$
\sigma^{77} \text { June 1, 1927. } 2 \text { ठ's, June 17, } 1927 .
$$

Ardea herodias herodias. Great Blue Heron.-From one to twelve of these birds were seen almost daily throughout the summer of 1927 and the spring of 1928. They came to the shallow borders of the bay and marsh to feed during each evening. Fish which had been discarded from nets out in the bay and which had drifted ashore seemed to form an important item of their diet. Such a habit cannot be interpreted as carrion-eating, however, since the fish secured in this way are often fairly fresh and well preserved.

This heron does not nest on Long Point and so far as we were able to ascertain the nearest nesting colony is situated in North Walsingham Township approximately ten miles north of Port Rowan. The birds which feed on Long Point and about the mainland shores of the bay are probably from this colony. Mr. Saunders has noted them at Turkey Point, Port Rowan and Long Point, etc., during spring and early summer trips made there since 1908 .

On July 14,1927 , while the writer was partially concealed by a bank on Second island, a great blue heron was seen to alight on the open bay about two hundred yards off shore. It would seem from the results of casual soundings with a punt pole that this bird could not have been resting on the bottom but that it was floating on the water. Its appear- 
ance and behaviour after alighting on the water was gull-like, the wings were carefully folded and the set of its head and neck suggested that the bird was floating, not standing. It took off without difficulty and settled a second time before being frightened away by my presence on shore.

Casmerodius egretta. EGRET.-McIlwraith (1866) states that this species "has been taken at Long Point" and Mr. W. E. Saunders has a record in his notes of a statement by G. F. Norval to the effect that Mr. Norval collected two at Long Point in the fall about the year 1888. Mr. Norval was a taxidermist and an observer of considerable ability who resided at Port Rowan. A more recent observation which conforms with a known northward incursion of this species (see Auk, October, 1930) was related to me by Mr. James Savage of Buffalo, N.Y. The guardian of the Provincial park at the base of Long Point saw "two large white herons" on July 3 or 4, 1930. A description of the birds and an estimate of their size was related to $\mathrm{Mr}$. Savage who concluded at the time that it could concern none other than the egret.

Florida cærulea. Little Blue Heron.- This species was recorded for the Long Point region as the snowy egret ("Ardea candidissima" = Egretta candidissima) by McIlwraith (1886) but the error was corrected in the second edition of this work published in 1894 . The following sight record, however, establishes the occurrence of the species more recently. While hunting near the base of Long Point on September 15, 1930, Mr. James Savage saw seven immature little blue herons. Coincident with this record there are several reports for 1930 of the species occurring in northerly sections of the eastern United States and Canada (see Auk, October, 1930, and January, 1931).

Butorides virescens virescens. Green Heron. A rare species on the point proper; it probably does not occur there in summer since we searched many of the wet flats, where shrubby growths appeared to be suited to it, without success. A spring specimen was secured however, and it is possible that a few green herons may inhabit some of the stream courses along the mainland. Mr. W. E. Saunders has not listed the species during any of his several trips to Port Rowan, Turkey Point and other places in the vicinity. Mr. W. E. Clyde Todd saw one near Port Rowan on July 13, 1907, and there is a specimen in Mr. William Smith's collection at Port Rowan taken locally. The late Mr. C. W. Nash had informed Mr. J. L. Baillie of a nest of this heron found at Port Dover, which is immediately outside the area here considered, in 1879. Bent (1927a) gives the latest date of departure for this species in the fall at Port Dover (which is somewhat outside the area considered in this report) as September 24, 1916. 
Nycticorax nycticorax nævius. Black-Crowned Night Heron. - So far as has been ascertained there is only one record of this species from the Long Point region. A specimen mounted by Mr. G. F. Norval which is in the collection of Mr. William Smith of Port Rowan is said to have been taken from a flock of two or three hundred at least thirty years ago, according to the personal notes of Mr. W. E. Saunders.

Rallus elegans. KING RAIL.-A mounted specimen in the collection of Mr. William Smith of Port Rowan taken locally a number of years ago is the only specimen of this rail from the region so far as the writer is aware. However, Mr. C. K. Rogers of Toronto, a hunter who knows the water birds very well, states that a pair of King rails reared a family of young near "The Cottages" during the summer of 1926. Mr. C. H. Ferris of Port Rowan also states that he has seen the species in the marshes of the point.

Rallus virginianus. VIRGINIA RAIL.-Apparently not common in the sections visited by us. We noted the species on only two occasions during our two visits to the point, and it would seem certain that the characteristic notes of this rail would have attracted our attention during May if it had been plentiful. According to Mr. Lorne Brown, the present keeper of the light, who has taken a keen interest in the kinds of birds which perish there, one was killed on the night of April 17 or 18, and three on April 20 or 21, 1930. Mr. W. E. Saunders has a record of another which struck the light on May 19, 1926.

Porzana carolina. SoRA.-Not common or generally distributed through the Long Point marshes so far as we could ascertain but noted on a few occasions. A nest of this rail was found at the border of the marsh near our camp on Second island but it had been partially destroyed and the eggs spilled into the water. The one egg which was recovered and preserved as a specimen was heavily incubated; it was found on June 17, 1928. Soras remain in the region at least until mid-October, one having been seen by Townson (1928) on October 14, 1927. Like the preceding, the sora sometimes falls prey to the light, Lorne Brown having picked one up dead which had been destroyed on the night of April 17 or 18, 1930, and another has been recorded by Saunders (1930) which struck the light between September 24 and 29, 1929.

$$
\text { o7 May 16, } 1929 . \quad 3 \text { 우 's May 16, } 1929 .
$$

Gallinula chloropus cachinnans. Florida Gallinule.-The local distribution of this species at Long Point closely resembled colonization, since groups of individuals inhabited favoured sections of the marshes while extensive areas were apparently not populated by them. Fortunately we were encamped near one of their chosen habitats while on Second island in 1927. Several pairs were established within a restricted part of the marsh, which did not comprise more than three or four acres. 
These birds presented an unusual problem. Although we lived and worked within one hundred yards of the centre of this colony, heard them daily throughout the early part of the summer, and found three of their nests which contained full complements of eggs, we scarcely glimpsed a single bird during the three weeks of our stay at this camp. However, we did establish the fact that these birds dive from their nests on one's approach and swim under water out of danger.

Several times we were mystified by hearing their call, like a mocking laugh, apparently coming from a bird within a few feet of us, although we could not see it. This failure to see the bird was the more mystifying since it occurred on a number of occasions while we waited motionless near its nest, sometimes standing among the reeds and again lying quietly on the bottom of a punt. The surrounding water was so sparsely vegetated as to give a visual radius of at least fifty feet. Our explanation of these occurrences was that the gallinule's approach was accomplished under water and that it protruded its bill and eyes behind some frail reed-stalks to observe us and to utter its call, which advertised our presence to the marsh generally.

Credit is due to Mr. A. R. Van, a visitor to our camp and an excellent wild life photographer, who finally succeeded in procuring photographs of a Florida gallinule. Dressed in a complete suit of reeds and with drooping hat to match, he waited patiently for twenty-three hours during two days before the bird could be photographed.

During our search for nests three new but unoccupied nests were found near occupied ones. They were constructed in the same manner as were the used nests, being anchored to reeds and capable of shifting vertically with the ever changing water level of the marsh. The tops of the reeds to which all of the nests were attached were bent inward giving to the whole structure a basket or bird-cage appearance. It was suspected that the unused nests were used as platform look-outs but we were not able to make observations that would substantiate this. It is possible that they were a manifestation of a more or less superfluous nest building instinct in the species, perhaps in the male, such as is observed in the case of marsh wrens.

The largest set of eggs found by us contained thirteen when the clutch was completed. These we collected on June 10, 1927, and they were all found to be fresh or only slightly incubated.
$\sigma^{7}$ May 15, 1929.
우 June $10,1927$.
우 May 15, 1929.

Fulica americana. Coor.-A rare summer resident but very common in the spring and fall. The coot returns in the spring in early April, remaining in considerable numbers until the early part of May. Bent (1927a) gives the earliest date of arrival at Port Rowan as March 
16, 1884. Mr. Todd mentions in his notes having seen the coot on July 12,1907 . We received a report from local fishermen on June 12, 1927 , that a coot had been seen by them in the open water of the marsh that day. These instances appear to be the only definite records for summer but Mr. C. H. Ferris of Port Rowan states that he has known them to summer in the region. In the fall coots return to the Long Point marshes in large numbers and remain until the freeze-up. Townson (1928) noted hundreds on the inner bay on October 28, 1927.

$$
\text { o' May 4, } 1928 .
$$

Rubicola minor. WooDCock.-The species finds conditions on Ryerson's island suitable for nesting and a few pairs occupied that area during the summer of 1927. A nest containing four fresh eggs was discovered on June 2, 1927, and another nest with an incomplete clutch was noted on the same day. We did not discover other areas on the point where suitable conditions for this species prevailed, nor did we secure records from the mainland but it seems entirely probable that woodcock may be found there particularly at Turkey Point. They are doubtless less common on Long Point as summer residents and as migrants than they were in early days. Giles (1880) implies that they were a common game bird in the region fifty years ago.

\section{우 June 2, 1927.}

Gallinago delicata. Wilson's Snipe. During May, 1928, the characteristic nuptial flight of this species was regularly observed over Second island and Snow island. In the summer of the previous year Wilson's snipe was not seen until July when two specimens were collected. A few pairs doubtless nest in the vast stretches of low grassy islands of the marsh each year, but it is no longer a common species in summer.

Early records state that snipe were formerly abundant on Long Point in the shooting season. Smith (1851), Small (1866) and Giles (1880) all remark on the excellence of snipe shooting in the area, but at the present time it is not an abundant species although it still appears in some numbers in the fall according to local sportsmen. Bent (1927b) gives November 2 as the latest date of departure from Long Point.

우 July 11, 1927.

Im. ơ July $12,1927$.

Limnodromus griseus griseus. Dowrtcher.-Observed on only three occasions; one seen on May 18, two on May 24 and one on May 25, 1928. The species is doubtless a rather rare migrant in spring and probably the same is true for the fall.

The three specimens collected are fairly uniform in plumage, all exhibiting fairly fresh nuptial dress. The feathers of the dorsal region retain a considerable margin of rich buff and there is only an occasional 
feather from the winter plumage remaining, except on the wings; ventrally the birds are rather uniformly pinkish cinnamon, except on the belly which is white, closely and finely spotted with blackish. A table of measurements of the three specimens is given below.

\begin{tabular}{l|c|c|c|c|c}
\hline R.O.M.Z. No. & Sex & Wt. in gms. & Length in mm. & Wing in mm. & Culmen in $\mathrm{mm}$. \\
\hline $28,5,30,20$ & $\sigma$ & 110 & 261 & 145 & 55 \\
\hline $28,5,30,21$ & $\wp$ & 114 & 275 & 142 & 63 \\
\hline $28,5,30,22$ & $\%$ & 113 & 268 & 137 & 59 \\
\hline
\end{tabular}

The specimens have all been referred to griseus, the markings and colour of the ventral surface agreeing with the recognized characters of that form and the measurements conforming fairly closely with averages of eastern birds. It is recognized, however, that the wing length of the male and the culmen length of one of the females is large, being within the range of size for scolopaceus.

우 May 18, 1928

ऽౌ May 24, 1928

ㅇ May 24, 1928

Micropalama himantopus. STILT SANDPIPER.-In the notes made by Mr. Todd in the summer of 1907 the following entry under date of July 16 was made:- "Here was a flock of Least Sandpipers, and as I watched them through the glass I made out a couple of Stilt Sandpipers in the deep water, feeding by plunging their bills down into the slime and withdrawing them again in a very peculiar fashion. By making a long crawl I was lucky enough to get both birds at one shot. Although in worn summer plumage there is nothing in their physical condition to suggest their being pensioners___-" We secured no other records of this species for the area.

Calidris canutus. KNOT.- Noted as a regular but not an abundant spring migrant. The earliest date of arrival obtained by us was May 24, 1928, when ten were seen. According to our records the latest departure date in spring was June 4, 1927, two birds having been noted.

The knot was primarily an inhabitant of the beaches although we occasionally saw it on the mud flats. Eight of the ten specimens collected are almost completely changed to nuptial plumage. Two, however, taken on May 29 and June 3, 1927, respectively, show considerable of the winter plumage, both ventrally and dorsally.

The only information relative to the species in the fall for the Long Point region is that of Hobson (1906) who states that he shot one at Port Rowan on September 19, 1905. It is probable that the knot appears 
in about the same numbers on its southward migrations as it does in the spring.

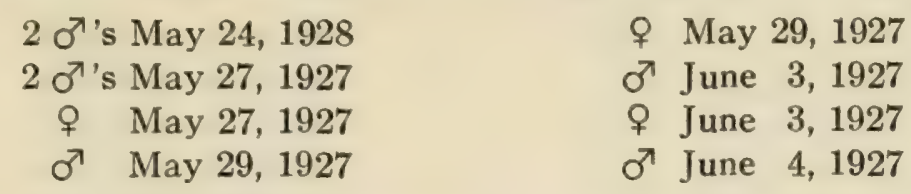

Pisobia maculata. Pectoral SandPiper.-As might be expected, no spring records of this species were secured by us, since it is doubtless rare in this region in spring. There is, however, a dated picture of this sandpiper in the Pope collection (Locke, 1917) indicated as April 24, 1843. This was probably based on a locally taken spring specimen. Three specimens in the Museum's collection secured at Port Rowan in October by Mr. G. F. Dippie give us the only definite record of the species for the region of Long Point. It is probably of regular occurrence there on its southward migrations.

우 October 12, 1898

ㅇ October 14, 1898

万' October 15, 1898

Pisobia fuscicollis. White-RUMPed SANDPIPER.--Four of these birds were seen on June 18, 1927, this observation being the only record for our party for the species. In the notes of Mr. W. E. Saunders he records two seen at the Long Point lighthouse on May 31, 1908. It is unquestionably a scarce spring migrant in the region and probably a similar status as to numbers prevails in the fall. The record made of this species on June 18, 1927, was the latest date for any northward moving shore-bird obtained by us at Long Point.

2 우's June 18, 1927

Pisobia bairdi. BAIRD's SANDPIPER.-Our only record is of one seen by Mr. W. E. Saunders in the vicinity of Long Point on June 7 or 8 , 1925.

Pisobia minutilla. LEAST SANDPIPER.-The earliest arrival date secured by us was May 4, 1928, the individual having been collected. Least sandpipers did not appear in numbers until mid-May at which time, and for some time thereafter, they were observed regularly. They were associated at times with flocks of red-backed and seimipalmated sandpipers. Our latest record in spring was made on June 2, 1927, a single individual having been noted. The species reappeared on its southward migration on July 6 , it having been the first of the migrating shore-birds to reappear in the region so far as our records indicate.

All of the specimens obtained in July are strikingly dark dorsally, the light margins of the feathers having been largely lost by wear. This condition of the plumage, together with remarks made on the appearance 
of the gonads when the birds were dissected, suggests that these individuals were non-breeding sub-adults.

\begin{tabular}{|c|c|c|}
\hline$\sigma^{7}$ & May 4,1928 & ㅇ July 6, 1927 \\
\hline 2 우's & May 11,1928 & 우 July 10,1927 \\
\hline$\sigma^{7}$ & May 15,1928 & శ’ July 11, 1927 \\
\hline $2 \sigma^{7 \prime}$ & May 16,1928 & 우 July 11,1927 \\
\hline 우 & May 26,1928 & ㅇ July 14, 1927 \\
\hline 우 & May 27,1927 & ণ July 22,1927 \\
\hline$\sigma^{7}$ & July $\quad 6,1927$ & \\
\hline
\end{tabular}

Pelidna alpina sakhalina. RED-BACKED SANDPIPER.-The information which we secured relative to the migration of this species largely concerns its movements in spring. The earliest arrival noted by us was that of an individual secured on May 12, 1928. By May 17 it was a common species, flocks of from six to twenty individuals being seen daily. It was of common occurrence until the end of the first week in June, after which individual records only were noted. Our latest spring record was made on June 15, 1927.

Red-backed sandpipers were birds of the beach and also of the mud flats. They usually flocked together, but were occasionally associated with other species such as least sandpipers. The species had not reappeared from the north at the time of our departure on July 26, 1927. According to Mr. W. E. Clyde Todd's notes he collected two specimens on July 16, 1907, but one of these was a wounded bird and the other was suspected of being a "pensioner". Hobson (1906) states that flocks of red-backs were seen on September 19, 1905, at Port Rowan. Bent (1927b) gives November 2 as a late date of departure in the fall from this region.

$$
\begin{aligned}
& \text { 万' May 12, } 1928 \\
& \text { o } \text { May 14, } 1928 \\
& 2 \text { 우's May 16, } 1928 \\
& 3 \text { o''s May 17, } 1928 \\
& \text { 우 May 17, } 1928 \\
& 2 \text { "7's May 19, } 1905 \\
& 7 \text { o's 'say 19, } 1928 \\
& \text { 우 May 20, } 1928
\end{aligned}
$$

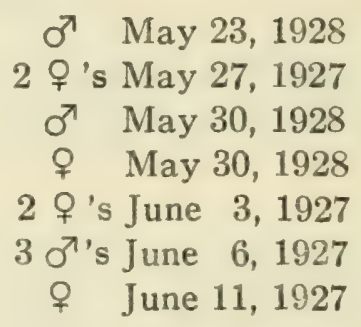

Ereunetes pusillus. Semipalmated Sandpiper.-A common shore-bird on Long Point from mid-May to the beginning of the second week of June, being found along the beaches and on the mud-flats; often found in mixed flocks with the least sandpiper. The largest single flock of shore-birds noted was composed of this species only, so far as could be ascertained. Our earliest spring record for the species was made on May 8, 1928, and the latest on June 16, 1927. The species reappeared on its southern migration on July 17, 1927. It was seen in small numbers after that date but it was not as yet common when we left on July 26 . 
A fall date is given by Saunders (1930) when he records a bird killed at Long Point lighthouse between September 24 and 29, 1929.
के May 14, 1928
वे May 16, 1928
2 웅 May 16, 1928
ㅇ May 20, 1928
o' May 22, 1928
2 o' 's May 23, 1928
2 우's May 23, 1928
ㅇ May 24. 1928
3 ox's May 25, 1928
ㅇ May 25, 1928
ठ May 27, 1927
2 우's May 27, 1927

Ereunetes mauri. Western SANDPIPER.-The taking of an adult female of this species in worn nuptial plumage on July 11, 1927, by Mr. John Edmonds was of special interest. It constituted, so far as is known, the fourth specimen ever to have been taken in the province (Snyder, 1928b). When this bird was observed in life it was casually associating with least sandpipers and its larger size attracted our attention to it. The bill appeared somewhat decurved like that of the red-backed sandpiper, a character which is apparently more conspicuous in life than in the preserved specimen.

The occurrence of this species in the region is very curious, particularly because of the date of its appearance. A spring migrant would, perhaps, be less surprising, but it seems that this individual was either moving southward or was merely a roving individual. There are no inland records which trace a northern continental crossing of the species, either in spring or fall, and according to our present knowledge its breeding grounds are confined to the coastal regions of northwestern Alaska.

우 July 11,1927

Crocethia alba. Sanderling.- Seen on only three occasions as a spring migrant during our two periods of stay on Long Point. The first record was of a specimen observed on May 25, 1928, and the other two records were of individuals collected on May 30 and June 4, 1927, respectively. It seems probable that greater numbers visit the area in spring than our records indicate; they may occur principally on the outer, lakeward beach, an extensive area which we were not able to reconnoitre regularly. The first record of southward moving sanderlings was made on July 17, 1927, one of a pair having been collected. Four others were seen on July 21 . Greater numbers probably appeared after we left camp near the end of July. Townson (1928) saw three on October 23, 1927.

$$
\begin{array}{ll}
\text { 우 May } 30,1927 \\
\text { ㄱ June 4, } 1927
\end{array}
$$$$
\text { ○ึ July } 17,1927
$$ 
Limosa fedoa. Marbled Godwit.-A specimen of this species in the collection of $\mathrm{Mr}$. Wm. Smith of Port Rowan, taken locally a number of years ago, is the only record from the area so far as is known to the writer.

Limosa hæmastica. Hudsonian Godwit.-A specimen, apparently taken in the fall, was seen by the writer in the collection of $\mathrm{Mr}$. Wm. Smith of Port Rowan. This bird which was taken locally is the only specimen seen by the writer from this locality, but Saunders (1926) has recorded one which was taken there in October or November, 1921. The latter specimen, apparently a mounted bird, was examined by $\mathrm{Mr}$. Saunders. There is one other record of the species for Long Point, that of Cottle (1859) who states that the specimen was possessed by him. $\mathrm{Wm}$. Pope has figured this species and dated the picture, October 11, 1844 (Locke, 1917).

Totanus melanoleucus. Greater Yellow-LEgs.-Found to be a fairly plentiful species during the first half of May, 1928, but we did not secure an early arrival date. According to local sportsmen these birds had returned at least two weeks before our arrival at Port Rowan on April 30. The latest spring record was of one collected on May 25. The earliest southward migrants as recorded by us were of four seen on July 21, 1927, associated with a rather large flock of the smaller species. Townson (1928) mentions a "heavy migration of greater yellow-legs during October, 1925." It is perhaps during this month that the bulk of this species passes south through this region. Bent (1927b) gives November 20 as a late date of departure for the species at Long Point.

These birds were largely frequenters of the mud flats and shallow bays in the marsh, but they were occasionally seen on the sandy beaches. The writer has noted, while concealed in a reed blind, that the greater yellow-legs can frequently be decoyed down by an imitation of either its rapid slightly descending, three-syllable whistle, "teeoo-teeoo-teeoo" or of its rolling musical "toowhittle, toowhittle, toowhittle", which is repeated eight to twelve times.

$$
\begin{array}{cc}
\sigma^{7} \text { May 3, } 1928 & 2 \text { क 's May 10, } 1928 \\
4 \sigma^{7} \text { 's May 4, 1928 } & \text { क } \text { May 11, 1928 } \\
\text { ㅇ May 4, 1928 } & \sigma^{7} \text { May 25, 1928 }
\end{array}
$$

Totanus flavipes. YelLow-LEGS.-We secured practically no information relative to the movement and numbers of yellow-legs in spring. Local sportsmen assured us that the species does appear in the region in early spring prior to the date of our arrival there in 1928 (April 30). On June 4, 1927, one thought to have been the yellow-legs was seen but it may have been the larger species. Bent (1927b) gives July 17 as an early date for the return of this species in the region on 
its southward migration. We were able to set an earlier record by securing a specimen on July 12, 1927. A few were noted regularly after that date and on July 21 , five days before we broke camp, thirty-five were noted.

$$
\begin{aligned}
& \text { ㄱ July } 12,1927 \\
& \text { ㅇ July } 17,1927
\end{aligned}
$$

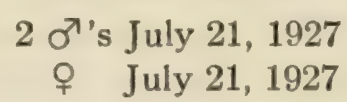

Tringa solitaria solitaria. Solitary SAndpiper.-The only record for the Long Point region is of a specimen collected by Mr. H. P. Stovell on May 6, 1928. This individual was taken on the muddy marsh border of a wooded island. An illustration of the solitary sandpiper is among the Wm. Pope paintings (Locke, 1917) and is under date of July 24,1859 . The subject was probably a bird taken in the region about that date.

\section{$\sigma^{7}$ May 6, 1928}

Actitis macularia. SPOTTED SANDPIPER.-A fairly common summer resident on Long Point and the adjacent mainland. The sandy ridges back of the beach on both the inner and outer sides of the point were ideal situations for this species to nest. A set of fresh eggs was taken in such a situation on June 1, 1927. Small flocks, probably family groups, were in evidence early in July. A wounded female was observed to swim into the lake when pursued, and Mr. Edmonds, the observer, stated that it swam well and high in the water.
万 May 12, 1928
ơ May 27, 1927
우 June 4,1927
우 June 6, 1927
우 July 4, 1927
万' July 8, 1927

Numenius hudsonicus. Hudsonian Curlew.-Fishermen engaged in netting carp in the Long Point marsh reported on May 24, 1928, that they had seen a few curlew fly over on that day. A flock of ten was noted by our party on the following day, four on May 27, and one on May 29. All of these observations were of birds flying overhead and we were unable to secure specimens. We were informed that curlew frequented Turkey Point on the mainland in some numbers between the first and last dates of our observations. A specimen taken locally was seen by the writer in the collection of Mr. Wm. Smith of Port Rowan.

Squatarola squatarola cynosurae. AMERICAN BLACK-BELlied Plover.-Our earliest record of this species was of a pair noted on May 7, 1928. On May 13 of that year the species appeared in some numbers and continued as a fairly common shore-bird until May 26, after which individuals only were observed. These straggling migrants were present until the end of our stay in 1928. Our latest spring record is of a specimen taken on June 16,1927. Although not a crippled bird 
it was not sexually vigorous as disclosed by dissection. The next latest date, which probably more nearly marks a normal ending of northward migration, is one seen on Long Point by Mr. W. E. Saunders on June 1, 1924. Townson (1928) noted the migration of this species on October 7 and 14, 1927. This is our only information on the species in the fall.

A discussion of the sexual difference as regards the plumage of this species based on the series of specimens collected in May, 1928, at Long Point, has been published (Snyder, 1930). It was demonstrated that the nuptial plumage of females probably never includes a completely dark ventral surface such as is possessed by most adult males in May, and that in this series of skins the female which exhibited the greatest amount of blackish feathers ventrally possessed more white than any male, there being a perceptible break in the series between the sexes when all of the specimens were arranged according to the degree of blackness or whiteness ventrally. It was further pointed out that there is also a difference of colour in the dark feathers of the two sexes, the dark feathers of males being intensely black and those of females brownish black.

The very slight differences of measurements as shown by the average of all males and all females in the series of twenty-one specimens taken in May, 1928, have apparently no significance as regards sex. Some measurements are as follows:-

\begin{tabular}{|c|c|c|c|c|c|}
\hline & $\begin{array}{l}\text { Weight } \\
\text { in gm. }\end{array}$ & $\begin{array}{l}\text { Length } \\
\text { in } \mathrm{mm} .\end{array}$ & $\begin{array}{l}\text { Wing } \\
\text { in } \mathrm{mm} \text {. }\end{array}$ & $\begin{array}{c}\text { Tail } \\
\text { in } \mathrm{mm} .\end{array}$ & $\begin{array}{l}\text { Culmen } \\
\text { in } \mathrm{mm} \text {. }\end{array}$ \\
\hline Largest $\sigma^{7}$ & 202 & 295 & 194 & 87 & 32 \\
\hline Largest ㅇ & 258 & 307 & 192 & 85 & 32 \\
\hline Smallest $\sigma^{7}$ & 170 & 274 & 177 & 77 & 30 \\
\hline Smallest 우 & 169 & 274 & 179 & 75 & 30 \\
\hline Average of $7 \sigma^{7}$ 's & 199.3 & 289.5 & 185.1 & 81.5 & 30.8 \\
\hline Average of 14 ㅇs & 203 & 290 & 185.6 & 78.1 & 30.7 \\
\hline 우 & May 7, 1928 & & 2 우's & May 21,1928 & \\
\hline $0^{+}$ & May 13,1928 & & q & May 23,1928 & \\
\hline 우 & May 13,1928 & & 우 & May 24,1928 & \\
\hline 우 & May 14,1928 & & 우 & May 25,1928 & \\
\hline 2 오's & May 15,1928 & & $2 \sigma^{7} \mathrm{~s}$ & May 26,1928 & \\
\hline q & May 16,1928 & & 우 & May 26, 1928 & \\
\hline $2 \sigma^{7} \mathrm{~s}$ & May 20, 1928 & & 우 & May 27,1928 & \\
\hline 우 & May 20, 1928 & & $\sigma^{7}$ & May 28, 1928 & \\
\hline $0^{7}$ & May 21,1928 & & 우 & June 16,1927 & \\
\hline
\end{tabular}

Pluvialis dominica dominica. Golden Plover.-We were informed by local sportsmen that this plover occurs in the fall, and Townson 
(1928), who has known these birds since the days of their abundance, records it as a migrant, on the nights of October 7 and 14, 1927.

Oxyechus vociferus. KilldeER.-More common on the mainland than on Long Point, but it was present there in small numbers. During mid-May, 1928, a pair had apparently selected the open ground around our cottage on Second island for nesting. During the early morning when the first faint light was perceptible they started their courtship music, the nature of which was new to the writer. Their long-continued, rapid "kee-a-wee, kee-a-wee, kee-a-wee", almost without interruption, was at least monotonous, if not quite annoying to us in our half-conscious sleep.

○' May 10, 1928

○า May 12,1928

Charadrius semipalmatus. Semipalmated Plover.-First noted in the spring of 1928, on May 7, four having been seen, one of which was collected. It was not common until mid-May but continued to be present in numbers until near the end of the month, the latest date on which it was recorded by us being May 30, 1927. Mr. W. E. Saunders, however, saw two in the region on June 7 or 8,1925 . The first appearance on their return in the fall was noted on July 22, 1927, an adult having been collected. They probably appear in numbers in this region during early fall. This plover frequents both the sandy beaches and the mud-flats at least during its spring migrations.

On May 19, 1928, while watching from a blind, the writer saw a performance which appeared to be a mating solicitation. A semipalmated plover, with its breast puffed out, one wing extended and raised, and with its head lowered, repeatedly advanced toward another bird of its kind with a rapid run, uttering as he advanced rather lowpitched chuckling notes. The ordinary call of this species is less plaintive and "piping" than that of the piping plover. It is a rather weak, musical "chooéep".

\begin{tabular}{|c|c|c|}
\hline May 7,1928 & $\sigma^{7}$ & May 22,1928 \\
\hline 3 ơ's May 14,1928 & $0^{7}$ & May 27,1927 \\
\hline o $\quad$ May 15,1928 & $\sigma^{7}$ & May 29,1928 \\
\hline 2 우's May 15,1928 & $2 \sigma^{7} \mathrm{~s}$ & May 30,1927 \\
\hline 2 శ'?'s May 16, 1928 & 우 & July 22,1927 \\
\hline
\end{tabular}

Charadrius melodus. Piping Plover.-The piping plover was present at the time of our earliest arrival on Long Point, May 1, 1928. At that time they had not settled down to nest and apparently transient individuals were still wandering about parts of the shore which were not inhabited by the species in summer. We noticed that these moving birds were active at night. They were frequently heard after dark from our camp on Second island in 1928 as they passed up and down the bay shore. This shore was not used as a nesting situation, in fact, 
after the conclusion of migration, they were not noted away from the main lake-shore beach during the previous summer. The species was rarely noted on the mud-flats in spring.

This summer resident plover was one of the most interesting species which we regularly observed at Long Point. It was recorded as a probable breeding bird of Long Point by Macoun (1900). Verification of this was made by Mr. W. E. Clyde Todd in 1907 when he secured a downy young there on July 16 and Mr. W. E. Saunders has several sets of eggs in his collection which were taken there in May, 1905, and May, 1908. Our party secured its first set of four fresh eggs on May 14, 1928, and the earliest date on which we observed downy young was July 4, 1927. The only fall date for the species which has been found is that of a young specimen collected at Port Rowan by Mr. W. D. Hobson of Woodstock, on September 19, 1905 (from W. E. Saunders' notes).

To the writer, the piping plover is one of the most outstanding examples of protectively coloured animals. When quiet, as they frequently are for long periods when they are not aware of the presence of humans, they blend perfectly with the colour, tone and pattern of their pebble and dry sand habitat. The young are also remarkably concealed by the colour of their downy plumage and by their habit of crouching quietly when danger is imminent.

An interesting feature in connection with the concealment of the young may be related without any attempt whatsoever of correlating the circumstances which are doubtless accidental. Cottonwood trees which grow on Long Point are almost entirely confined to the sandbanks immediately back of the beaches. During the period immediately after these trees had shed their down-transported seeds in the summer of 1928 , the young piping plover hatched from the eggs. The cotton from these trees, which is in colour very like the down of young piping plovers, scattered over the beaches, and the wind rolled it into loose balls about the size of young plover. On the particular day that we were searching for and pursuing young plover the nature and velocity of the wind along the beach produced about the same speed and interrupted movement in the cotton balls as was observed in the case of the young birds! This has been related merely as a striking coincidence.

The notes of the piping plover strike one as being soft, plaintive and extremely musical. The simple, piped "peepoo" is very like the notes of the more or less obsolete instrument, the ocarina. The second syllable of this call is usually a musical half-tone lower than the first. The other common call which, to the writer, sounds like a gentle interrogation, is a smoothly slurred "weep, weep, weep" etc. By association, these are sounds of open, extensive beaches and boundless blue water glimmering with the heat and light of the summer sun. 
The broken-wing ruse which is so well known among many birds is highly developed in this species. This plover's execution of it suggests not only a broken wing but at times also a broken leg or legs; in fact, it appears to be completely crippled as it turns half over on its back, kicking its feet limply and extending its wings in a helpless manner.

After counting the number of piping plover which inhabited from two to three miles of the main south beach of Long Point, we estimated that the local adult population in summer would be one hundred pairs or more.

Of the eighteen adult specimens in our collection from Long Point all but one have a continuous band of dark feathers across the upper breast and in this case the band is only slightly interrupted.

\begin{tabular}{|c|c|}
\hline $4 \mathrm{o}^{7 /} \mathrm{s}$ & 7,1928 \\
\hline 5 웅 & May 7,1928 \\
\hline$\sigma^{7}$ & May 10,1928 \\
\hline & May 12,1928 \\
\hline$\sigma^{7}$ & May 27,1927 \\
\hline & May 27,1927 \\
\hline$\sigma^{2}$ & May 27,1928 \\
\hline
\end{tabular}

o' May 28, 1927

क May 29, 1927

우 May 30,1927

$2 \sigma^{7}$ 's July 4, 1927

ㅇ July 4, 1927

우 July 8,1927

Arenaria interpres morinella. Ruddy TuRnstone.-Our earliest arrival date for this species was obtained on May 14, 1928, but it was not common until May 23. It is one of the most numerous shore-birds at Long Point during the latter part of May, from six to fifteen being the usual number in close flock association. It is largely a bird of the sand and gravel beaches. Our latest spring record was made on June 17 , 1927, when four were seen, one of which was collected. Dissection of the collected specimen revealed that the gonads were small and apparently not in a functioning condition, but it would appear that these late migrants, which were apparently not to nest that year, passed on northward since no others were seen after that date. The greater number, however, had gone northward by the end of the first two days of June.

Turnstones are very interesting birds to watch while they are feeding and remind one very much of common domestic pigeons as they walk the beach in search of food. They are sometimes slightly quarrelsome, old males tending to dominate the feeding ground by occasionally giving chase to other individuals which are apparently infringing on their right-of-way. This quarrelsomeness, slight though it may be, is of particular interest, since it seems so contrary to the usual social, meek and delicate shore-bird nature. The business of food-hunting of the turnstones is prosecuted with vigour and energy at times. As the flock moves along, there is a constant interchange of individuals in the rank, those in the front tarrying to pick up a morsel while those farther back hurry to the lead. Their bills are deftly used to flick objects aside in 
the search for food and frequently these objects are stones, which discloses that their name has been aptly chosen.

Nearly all flocking shore-birds have developed wonderful coordination of the individuals in flight within the flock. This unity of movement in the air is very striking with the ruddy turnstone because of its rather large size and contrasting colour pattern. The flock lifts, wheels, forges onwards, drops, banks and settles as if it were a close$\mathrm{knit}$ thing in itself rather than a group of independent individuals, bound perhaps only by instinctive reflexes, or, capable of instantaneous and voluntary reaction to the movements of a leader.

Although we have no information concerning the turnstone in the fall at Long Point and vicinity, our knowledge concerning its occurrence in adjacent areas suggests that it is to be expected during the latter part of August and the first part of September in some numbers as a southward moving migrant.

$$
\begin{aligned}
& \text { o } \text { May 14, } 1928 \\
& \text { 우 May 16, } 1928 \\
& \text { o } \text { May 20, } 1928 \\
& 2 \text { 어 's May 20, } 1928 \\
& \text { ơ } \text { May 23, } 1928 \\
& 2 \text { o's May 24, } 1928 \\
& 2 \text { 우's May 24, } 1928
\end{aligned}
$$

$$
\begin{aligned}
& \text { б May 25, } 1928 \\
& \text { o } \text { May 26, } 1928 \\
& \text { or May 29, } 1927 \\
& \text { 우 May 29, } 1927 \\
& \sigma^{7} \quad \text { May 30, } 1927 \\
& 3 \text { वु's June 1, } 1927 \\
& \sigma^{7} \text { June } 17,1927
\end{aligned}
$$

Colinus virginianus virginianus. BoB-wHITE.-After the forest had become cleared and cultivated areas became widespread in southern Ontario the bob-white spread over the countryside and remained a more or less plentiful species until the end of the nineteenth century. There were periods of scarcity which brought about legislation affording partial or complete protection for the species, but there was a gradual depletion of numbers throughout the whole period from the time of settlement to approximately 1900 when the species became too rare to attract further interest. During the early years in the eighteen-fifties when bob-whites were really abundant and market shooting was prosecuted on a big scale, Norfolk county ranked as one of the best districts for the business (Harris, 1905).

The earliest record of the species for Long Point is that of Need (1838) who remarks on the occurrence of the species in cleared lands in July, 1832. An earlier record which can only be attributed to the County of Norfolk is that of Harris (loc. cit.) who states that (about 1810) his mother heard a bob-white for the first time in the region. The new bird song was well known to a senior member of the family who had formerly resided in New Jersey where the bob-white was common. Bob-whites do not now occur on Long Point at the present time but it is said that a few may be found near Turkey Point. The progenitors of these living birds are quite probably largely introduced stock. A 
mounted specimen in the collection of $\mathrm{Mr}$. Wm. Smith of Port Rowan was taken at Turkey Point about thirty years ago and may represent original birds of the district.

Bonasa umbellus togata. Canada Ruffed Grouse.-Ruffed grouse are either completely extirpated or nearly so on Long Point but they still persist in the wet woods of Turkey Point and elsewhere on the mainland. Local hunters believe there may still be a few left on the point but the sparsity of undergrowth is a serious detriment to their welfare there. We did not secure a single record for the point during either of our visits but Mr. W. E. Saunders has noted one there as recently as June 1,1924 . Mr. R. V. Lindsay saw a few at Fisher's glen during July, 1927, and Mr. H. Fulcher found a nest with fourteen eggs there on May 3, 1931.

In the early days they were a common game bird of the region and we find such statements as that of Giles (1880), "the woods is largely supplied with partridges, etc." This species cannot exist plentifully in intensively cultivated areas but it seems regrettable that the peninsula of Long Point has been made so barren by browsing deer as to eliminate it as a ruffed grouse reserve.

No specimens from the locality have been examined, but a few specimens from the general region of southern Ontario indicate that, according to our present knowledge, birds from here may be considered as togata, but certainly showing tendencies toward umbellus.

Meleagris gallopavo silvestris. WiLd TURKEY.-Our earliest record for the turkey is that of Need (1838) who states that they were occasionally noted in July, 1832, in the woods and that they sometimes fed on maize which was raised by farmers on the point. He also remarks on the ease with which turkeys may be trapped. His description of the method of trapping turkeys is worthy of repetition, it being quoted as follows: "A small shanty or hut is built near their accustomed feeding place, with an opening in the side large enough to admit the birds, stooping; in and about this place grain is carefully scattered, which the birds pick up without suspicion, stooping their heads and feeding until they find themselves in the trap, then they raise their heads and make great efforts to escape at the top and sides, and in every way, excepting that by which they entered."

Turkeys were still a prominent game bird in the district in 1880 (Giles, 1880), but it had become extirpated throughout southern Ontario generally (McIlwraith, 1894) by the early nineties.

Turkey Point on the north shore of Long Point bay was doubtless given its name after this wild bird which at one time frequented its swamps and woods. 
Ectopistes migratorius. Passenger Pigeon.-The earliest account of the passenger pigeon for this region is given by Howison (1821) who states that "Immense flocks. . . frequent this (Long Point) and other parts of Upper Canada during spring and autumn; and myriads of them are killed by fire-arms, or caught in nets by the inhabitants; for they fly so closely and in such numbers that twenty or thirty may sometimes be brought down at a single shot. ..." In the diary of $\mathrm{Wm}$. Pope (only a part of which has been available) there is an entry under date of September 15, 1842, stating: "Shot a pigeon: there were three, but I only got one shot." Other entries state that one had been shot on each of the following days, September 18, October 11 and October 14. All of these concern the vicinity of Port Rowan and Long Point. Wm. Pope (Locke, 1917) also painted two pictures of this species, one of two adults and the other of a young bird; the latter is dated June 30,1860 . Although available information on this species is meagre, the dates are of interest and it is established that the species was a plentiful migrant at Long Point and vicinity in the early part of the nineteenth century. Pope's picture of a young bird painted in late June suggests that the passenger pigeon may have nested in the region.

Zenaidura macroura carolinensis. Mourning Dove.-Apparently not a nesting inhabitant of the point but well distributed on the adjacent mainland. Our party made only one record of seeing the species on the point proper and in this case it was a single bird on the wing. Our records of observations at Port Rowan include the species and Messrs. W. E. Clyde Todd, W. E. Saunders and R. V. Lindsay have noted it elsewhere on the mainland at various times where it is not uncommon. A spring migration date is indicated by a communication from Mr. Lorne Brown who states that one was killed at the light on April 17 or 18, 1930.

$0^{7}$ May 4, 1928

Circus hudsonicus. Marsh Hawk.-The writer has already made record of the occurrence of this species at Long Point (1928a). From one to six marsh hawks were seen daily as they hunted over the marshes, and one might have been inclined to over-estimate their numbers if the openness of their habitat and the resultant visibility had not been considered. They nest on the drier, grassy islands of the marsh. One nest which was found on June 4,1927 , contained five eggs in a rather advanced state of incubation. Adult males and females were the usual phases noted in spring and early summer, until the season when the young of the year were on the wing, but some birds in the brown plumage of immaturity were observed. A young male in the more or less brown 
phase was collected on May 5, 1928. When collected, the feathers possessed a marked amount of bloom most of which was lost while handling the bird in preparation. There is still a slight amount of this curious colour on the tertials. The feathers generally are abraded and there appears to be no replacement in any area although the tertials and some of the feathers of the dorsal region are not badly worn. It would seem that this individual was entering its third summer.

One curious observation relative to the food habits of this species was made on the specimen collected May 5 . When shot it was feeding on the plucked body of a red-headed woodpecker. Upon examining the woodpecker it was found to be infected with fly eggs within the abdominal cavity. The bird may have been captured and left for a time or perhaps the marsh hawk had accepted a bird found dead. The time required to pluck and partially consume the body would scarcely allow for fly infection, especially early in the month of May.

An observation concerning the habits of this species, which is also relative to feeding, is of especial interest. The following remarks relate to a family under casual observation near our camp on Courtright ridge, although similar observations have since been made elsewhere. When the young marsh hawks first leave the nest they become scattered about the wet flats and each in turn is searched out by the parent bird when the latter returns with food. (So far as our field observations indicate, the young are fed on small mammals, principally meadow mice.) For the first few days the parent bird settles to offer the food. Soon the eager young utilize their limited powers of flight by springing into the air a few feet when the parent bird flies over at a low altitude. The food is dropped and the young bird immediately retrieves it from the ground. In a few more days, however, the young are more active and promptly leave their low perch when the parent is seen approaching at a considerable distance. The adult was several times seen to fly, at a high altitude, over the area where the young were located. The young, sometimes only one, and at other times two or three, would rapidly gain altitude until they were flying immediately below the adult. A mouse or similar object would then be dropped by the parent and the young would catch or attempt to catch the object in mid-air. Although this feat was observed only three times, it appeared to be an established habit. Only once out of the three observations was the object missed by the young, which, however, did not attempt to retrieve it.

A performance such as related above, if it concerned certain species other than the marsh hawk, might be interpreted as a kind of parental training which has been evolved to aid young birds in capturing their prey. With this species, the meaning of such behaviour is obscure. The species usually secures its prey from the ground, more rarely striking 
it down from the wing. It might be suggested that the development of such a habit is most useful to the species in that it is a notable timesaver. The time and energy required to hunt and capture food for four or five (or more) young which are nearly adult in size, undoubtedly places a heavy demand on the parent (or parents, the female only being noted in the above observations) which must also secure food for its own existence. In a year of food scarcity the early development of precocity in the young would be particularly important. One can readily appreciate the value of the co-operation of the young as related above at such a time, since the parent can uninterruptedly continue its foraging for food.

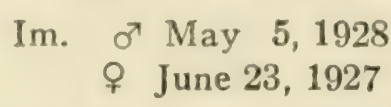

Accipiter velox. SHARP-SHINNED HAwk.-Although the species occurs in the region at least as a migrant, it is apparent that it does not occur in any such numbers as at Point Pelee, farther west (Taverner and Swales, 1907 and 1908). We secured a specimen from Port Rowan taken May 4, 1928, and another was seen on Ryerson's island on May 6 of that year. These are the only records made by us during the two periods of encampment on the point. In the notes of Mr. W. E. Saunders he records having seen one in the region on May 31, 1908, and in his published account of lighthouse destructions (1930) he mentions sharpshins moving along the point towards the end and seeing them coursing about all day on September 11, 1930.

\section{Im. o' May 4, 1928}

Accipiter cooperi. Cooper's HAwk.-Two records of occurrence are made in the notes of Mr. W. E. Saunders; one was seen on August 25, 1918, at Port Rowan, and one on June 7 or 8,1925 , in the vicinity, probably at Turkey Point.

Astur atricapillus atricapillus. GosHawk.--The only record for this species is a specimen, taken locally, in the collection of $\mathrm{Mr}$. Wm. Smith of Port Rowan. However, descriptions of hawks which visit the area in the fall, as related to the writer by local sportsmen, suggest that this species may occur frequently at that season.

Buteo borealis borealis. RED-TAILED HAwK.-An interesting specimen of this species was collected on Ryerson's island on May 9, 1928. It is in worn first winter plumage, being approximately one year old. The plumage is badly worn and bleached and at this date there is only slight feather replacement among the scapulars and interscapulars. The tail is very much faded, the background being a dirty buffy gray while the ten narrow broken cross bars are faded brown. 
Our investigation on Long Point failed to establish this species as resident there in summer and it is apparently rare in the vicinity on the mainland.

Im. 우 May 9, 1928

Archibuteo lagopus sancti-johannis. RougH-LEGGED HAwK.Our only specimen is a skin reduced from a mount. It was taken a few years ago in the Long Point marsh. In Mr. W. E. Saunders' personal notes he mentions having been shown two of these birds with "whitish heads streaked with dusky and not the usual buff colour." The species probably occurs in the region regularly in late fall.

Im. ? late October, 1924

Haliæetus leucocephalus alascanus. Northern BALd EAgLE. -Early references show that this territory has been occupied by the bald eagle since the time of settlement. Charles Durand (1897) mentions that "eagles" were noted there as early as 1827, and Need (1838) speaks of the eagle being seen harassing the osprey there on July 12,1832 . It has been recorded as a breeding species on Long Point by Halkett (1898).

Long Point is one of the few remaining nesting areas of the bald eagle in southern Ontario. A nest of the bald eagle on Ryerson's island has been a landmark in the district for years. During our visits to Long Point in 1927 and 1928 the nest was occupied and young were reared during the former year. The nest was situated approximately thirtyfive or forty feet up in a cottonwood, this particular nest having been there for several years.

Certain of our observations, made in the summer of 1927 , suggest that another pair nests in the vicinity eastward from the lakeward end of Squire's ridge. We did not succeed in locating such a nest but the behaviour of birds seen regularly in that section certainly indicated that we were not far from a nest. Eagles were noted almost daily but this was because of the close proximity of our camps to a nesting site. The greatest number seen on a single day was five; the circumstances were such that it was considered that no individual had been recorded twice.

$\mathrm{Mr}$. Angus Buchanan has informed the writer that a pair of eagles has nested on the mainland about two miles in from the lake, midway between Port Ryerse and Fisher glen, for the past twenty years. Two nests are present and these birds appear to occupy them on alternate years.

From our casual observation about the nest on Ryerson's island and along the beach, this species feeds exclusively on dead fishes, many of which are washed ashore after having been discarded by fishermen. Hunters in the region state that these eagles sometimes take wounded ducks in the fall. The general attitude of sportsmen in the region is 
favourable to eagles. They are unmolested and regarded with considerable interest and the property regulations of the Long Point Company affords them virtual protection.

Falco rusticolus gyrfalco. Gyrfalcon.-A specimen of this form in the collection of Mr. J. H. Fleming was taken at Long Point in the autumn of 1893. This specimen has been recorded by Macoun (1909) the same specimen having previously been recorded by him as G.r. obsoletus (Macoun, 1903). The name here used, F.r. gyrfalco, is in accordance with the A.O.U. check list of 1910.

Falco peregrinus anatum. Duck HAwk.-Mcllwraith (1866) records the species as occurring at Long Point where it preys "chiefly on that class of birds embraced under the general name of mud-hen". An immature specimen taken locally was seen by the writer in the collection of birds possessed by Mr. Wm. Smith of Port Rowan. Two illustrations of this hawk are among the Pope paintings (Locke, 1917), both of immature individuals. One picture is dated October 25, 1846.

Cerchneis sparveria sparveria. Sparrow HAw K.- The rarity of this hawk in summer is worthy of special note as one would expect that it would occur in fair numbers in this region since there are considerable areas of woodland adjacent to the cultivated land. One was seen by us near the end of the point on July 19, 1927, and another was noted flying across the flats on the lakeward end of Courtright ridge on July 23 of the same year. Mr. R. V. Lindsay did not see it at Fisher glen during July of 1927. The species was not recorded in the notes of Mr. W. E. Saunders which were made on his several spring and fall visits to the region since 1908 .

Pandion haliætus carolinensis. OsPREY.-An early record of this species has been made by Need (1838) who states under date of July 12, 1832, that ospreys were observed being robbed of their food by eagles. Apparently this hawk was established as a summer resident at that date. At the present time it is not known to breed in the area with which this paper is concerned. It has been seen, however, at a rather late date for a spring migrant, June 7 or 8,1925 , by Mr. W. E. Saunders, on Long Point bay.

Tyto alba pratincola. American Barn Owl.-Howe (1902) has recorded a specimen in the collection of the Museum of Comparative Zoology, Cambridge, Mass. (No. 1482) which was taken on the point in early November, 1899. Mr. Shelley Cook, former keeper of the Long Point lighthouse, told us that a barn owl was shot on the end of the point in the fall a few years ago. It has not been possible to trace this specimen although it was saved, but it seems safe to consider it a record distinct from the one mentioned above, since the year, given from memory, was considerably later than 1899. In the notes of Mr. W. E. 
Saunders, he states that members of the life-saving crew formerly stationed at the end of the point related that several were seen and shot there in 1920 or 1921.

Asio wilsonianus. Long-EARED OwL.-A few fresh feathers which could not have been long removed from one of these owls were picked up on Courtright ridge on June 25, 1927. We did not secure further evidence of its occurrence until a specimen was collected on May 22 of the following year. It is probably a rather rare resident of the district.

ๆ May 22, 1928

Asio flammeus. Short-eared Owl.-At least two pairs of these owls were established on Snow island during the summer of 1927 . Considerable time was spent in attempting to establish a breeding record of this species for Long Point and we were eventually successful when, on June 15, 1927, Mr. John Edmonds secured a virtually flightless young bird. The bird is in an interesting juvenile plumage which is characterized by the sooty facial mask and the rich reddish buff-coloured woolly feathers of the belly and flanks. This is one of the few records which establish the species as a breeding bird of Ontario.

We did not see this owl in the spring of the following year which may be accounted for by the altered condition of the flats due to floods the preceding fall. It may, however, have been present but unobserved due to the quiescence demanded by nesting duties. There are extensive areas apparently suited to this owl but we did not meet it elsewhere than on Snow island.

\section{Juv. ? June 15, 1927 o July 14, 1927}

Cryptoglaux acadica acadica. SAW-WHET OWL.-In the notes of Mr. W. E. Saunders he states that a former lighthouse keeper related to him how numbers of these owls were captured on Long Point by stretching a fishing net across pathways in the woods. Taverner and Swales (1911) have previously related this interesting account. This appears to be the only information relative to the saw-whet's migrations or movements on Long Point. We were successful in establishing the species as a breeding bird in the region. Mr. John Edmonds collected a juvenile specimen, not long out of the nest, near the south end of Courtright ridge on July 6,1927 . This obscure little species could easily be overlooked and the discovery of this specimen was of especial interest and value to our collection.

Wm. Pope (Locke, 1917) has figured the species, probably from a local specimen, under date of July, 1859.

Juv. ơ July 6, 1927 
Otus asio asio. SCREecr OWL.--Probably a regular resident of the region, but rather rare on the point proper. We heard it only once during our visits there, the occasion being on the night of July 6, 1927, while we were in camp on Courtright ridge. Macoun (1898) records it for Long Point on June 2, 1898. Mr. Lindsay noted one at Fisher glen during July, 1927.

Bubo virginianus virginianus. Great Horned Owl.-A resident of Long Point and probably of the wooded swamps of the adjacent mainland. The species was seen occasionally throughout the summer of 1927 and on one occasion, in May, 1928. No nests or young birds were seen.

On May 31, 1927, two adult great horned owls were flushed from the expansive treeless grass-flats on Snow island. It was mid-afternoon and the day was sunny, the birds probably being at rest rather than hunting at the time. The circumstances are peculiar, since the species usually rests during the day in trees in heavily timbered areas.

Nyctea nyctea. Snowy OwL.-The Long Point marshes are usually invaded by snowy owls during the pronounced southern flights of the species. Hunters told us that these owls may be observed on muskrat houses in the marshes and that they sometimes feed upon crippled ducks.

Baillie (1928) has recorded our observations on three individuals which inhabited the marsh in May and June of 1927 . They were remnant birds from the widespread flight of the species which took place during the fall and winter of 1926-27. The occurrence of these birds at so late a date is of interest since it indicates that the species can subsist in southern marshes and flats, remaining there until the nesting season is upon them and although both sexes are doubtless present, they do not become established there. Sporadic migrations seem to have little or no effect in animal distribution. The latest date on which the species was noted was June 13, the record being of an adult male (presumably) which appeared to be in normal physical condition. No snowy owls were seen after that date.

The interesting question arises as to what becomes of such birds as these. By way of discussion it is suggested that in the case of the snowy owl we are dealing with a species in which the instinct for periodic migrations is not highly developed. It does move beyond the southern border of its summer range each fall, which indicates a tendency to migrate, but it is not a migratory bird in a complete sense. The more or less irregular appearance of the species at low latitudes must present a problem to the species which, it would appear, cannot be coped with by a slight inherent tendency to migrate. Nowadays, great numbers of them are shot when they invade more southern, settled communities, 
but as to the eventual fate of the survivors we can only conjecture. With the approach of the nesting season and the resultant physiological changes within the individual which would act as a stimulus to mating impulses, each bird must become a wanderer without the inherent directional instinct for regular and extended migrations. It would seem that their arrival on distant breeding grounds would be more or less a matter of accident.

? about November 4, 1925 व about December 13,1930

Coccyzus americanus americanus. Yellow-Billed Cuckoo.It was difficult to form a very exact estimate of the comparative numbers of this species and the next. It was discovered that the calls of the two species could not always be distinguished. Certain of the calls, however, appeared to be specific. Our records indicate that the yellow-billed cuckoo is not as numerous as the black-billed cuckoo. We saw it occasionally in suitable situations which were rather limited on the point. Mr. R. V. Lindsay found it established on the mainland at Fisher glen in the summer of 1927 , and $\mathrm{Mr}$. W. E. Saunders has also noted it during visits to the region in late spring and early summer.

We found the species nesting on the point. One nest discovered by Mr. John Edmonds was situated three feet from the ground in a button bush (Cephalanthus occidentalis) thicket. The nest contained three young in the curious stage of plumage in which the feathers are well developed but still sheathed. The young were quite active when disturbed. They scrambled about the bush, using the wings and bill for climbing. One young which was brought to our camp demonstrated a remarkable reptile-like behaviour. When it was placed on the table and one reached to pick it up, it erected its somewhat horny plumage and emitted a buzzing hiss like the sound of bees escaping from a tunnel in dry grass. This performance was certainly unbirdlike in all respects. An egg of this cuckoo was found in the nest of the black-billed species.

$$
\begin{array}{lll}
\sigma^{7} & \text { June } 21,1927 & \text { Nestling } \text { of July } 6,1927 \\
\text { o } & \text { June 21, } 1927
\end{array}
$$

Coccyzus erythrophthalmus. Black-BILled CUCKoo.-Our earliest arrival date for this species is May 19, 1928. Fall migration dates are afforded by two birds which struck Long Point light, one on September 7 and another between September 24 and 29, 1929 (Saunders, 1930). It was more common than the preceding, from one to five, having been seen daily in summer when we were encamped in a suitable area. It is also to be found on the adjacent mainland. The species nests in the buttonbush thickets on the point as did also the yellow-billed. A nest constructed in one of these thickets was found on June 24, 1927, by Mr. John Edmonds. It was placed two and one-half feet above the 
water and contained four fresh eggs of this species and one of the yellowbilled cuckoo.
ठํ June 4, 1927
우 June 24, 1927

Ceryle alcyon. Belted Kingrisher.--Generally distributed in the region as a whole but not common on the point. Young leave the nesting tunnel early in July and apparently follow the parent female to suitable fishing areas. The sand banks on the south beach of the point afford the most suitable situations in which to nest.

$$
\text { 万' May 29, } 1928 \quad \text { Juv. क July 11, } 1927
$$

Dryobates villosus villosus. HAIRY WOODPECKER.-Noted regularly in small numbers on the point and also to be found in suitable situations on the mainland. The species breeds in the region, young which had recently left the nest having been collected. The earliest date on which young were observed was June 29, 1927.

$$
\begin{aligned}
& \text { 우 June 4, } 1927 \\
& \sigma^{7} \text { June 23, } 1927 \\
& \text { Juv. व' June 29, } 1927 \\
& \text { " O July 1, } 1927
\end{aligned}
$$

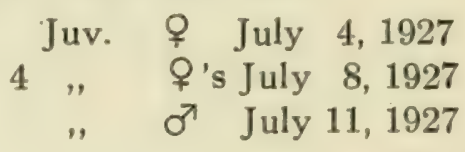

Dryobates pubescens medianus. Downy Woodpecker.--More common than the hairy woodpecker by two or three to one according to our records for the summer of 1927. From one to ten were seen daily while we were stationed in a woodland camp. It is equally as common on the adjacent mainland, and available records concerning this species and the last indicate a larger proportion of downy woodpeckers there than on the point. This would perhaps be expected since the smaller species seems less disturbed by settlement. The earliest date on which we observed young which had recently left the nest was July 4, 1927.

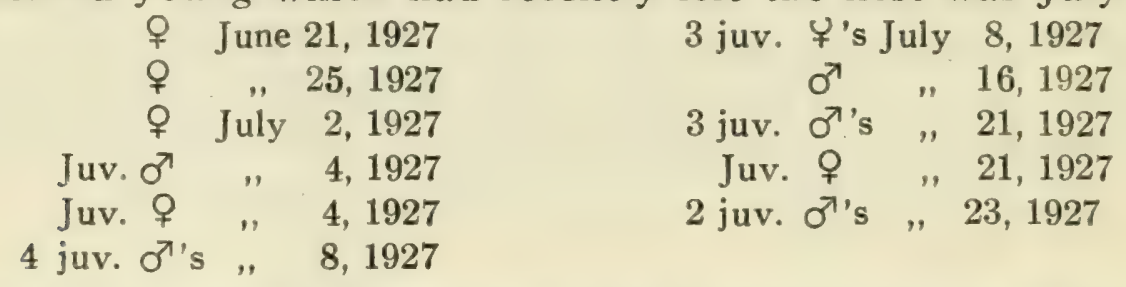

Picoides americanus americanus. THREE-TOEd WoODPECKER. -A most unexpected record of this woodpecker was obtained when a male specimen in the flesh was received at the Museum on May 25, 1928, from Mr. G. W. Knechtel who secured it at Turkey Point on May 19, 1928. The record, particularly at this date, is very unusual and accounting for it is difficult. It does not seem possible that the species could occur in the region as a relic member of the fauna. It is more probably an unusual and accidental winter visitant, the individual failing, through some cause, to return to the north. 
Sphyrapicus varius varius. Yellow-Bellied SApsucker.-A migrant in the region, passing through in spring before the time of our earliest arrival. Eight struck the Long Point light on April 17 or 18, 1930, and four on April 20 or 21 of the same year. A belated migrant was collected on May 12, 1928. A fall date of migration is given by Saunders (1930), a sapsucker striking the light between September 24 and 29, 1929. It was not seen on the point in the summer of 1927, and the name is not given in any late spring or summer list made on the adjacent mainland by Mr. W. E. Saunders or others.

ㅇ May 12, 1928

Phlcotomus pileatus abieticola. Northern Pileated WoodPECKER. - In the notes of Mr. W. E. Saunders he records having heard a pileated woodpecker in the Walsingham swamp and remarked that he believes it was in 1926 or later. The wooded swamp referred to is somewhat outside the area covered by our survey but Messrs. R. V. Lindsay and F. H. Emery saw one on May 10, 1931, at Turkey Point indicating that it may be found on rare occasions within the territorial scope here considered.

Melanerpes erythrocephalus. RED-HEADED WoOdPECKER.-A fairly common nesting species in the district and a common migrant. The first migrants noted were seen on May 4, 1928, and the latest date on which individuals were seen that were very probably migrants, was May 23 of the same year. Something of the migration of this species has been related in the introduction to this paper. This diurnal migrant also "falls prey" to the lighthouse, one having been killed there on May 19, 1926.
우 June 2, 1927
Nestling $\sigma^{7}$ June 29, 1927
3 Nestling $\subsetneq$ 's June 29, 1927

Colaptes auratus luteus. NorThern Flicker.-The resident form, luteus, is the only one represented in our collection. The northern representative, borealis, may occur as a migrant but we secured no evidence to prove the supposition. As a migrant the species is common, it having been noted in the region at the time of our earliest arrival, on April 30, 1928, and numbers continued to move past our Second island camp until May 13. The last specimen noted, which was apparently a transient bird, was seen on June 3,1927 . Remarks on this species in migration are included in the introduction. The flight observed by Mr. James Savage on September 30, 1930, was very remarkable, individuals estimated to be from one to two hundred yards apart, forming a scattered and straggling flock, passed in an almost steady stream throughout the morning hours. The flicker is a fairly common nesting species in wooded sections of the point and the adjacent mainland. Two 
juvenile males collected on July 7,1927 , have a strong suffusion of red in the feathers of their crowns.

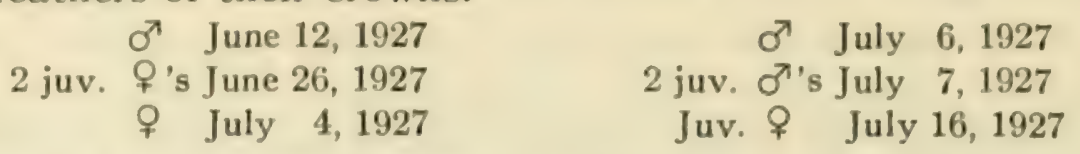

Antrostomus vociferus. WHIP-POOR-WILL.-Heard on a few occasions during May, 1928, but not seen or heard in the summer of 1927. The point is not very well suited to the whip-poor-will at the present time because of the cleared condition of the forest floor, but a few pairs may be established there. In the early days it was probably more common. Macoun (1898) records the species from the point but does not state the numbers observed. The species is established in suitable situations on the mainland, but according to available information it is not very common.

Chordeiles virginianus virginianus. Nightнаwк.-Rather rare on the point but more common on the mainland. The species appeared to be established as a nesting bird on Ryerson's island in 1927, but we did not get definite information to prove the point. However, it is a summer resident of the region generally.

Chætura pelagica. Chimney Swift.-Our earliest record of the species was made on May 15, 1928, but it no doubt arrives earlier than this record would indicate. A few were seen at irregular intervals throughout both periods of our visits to the point. It is more common on the mainland than on the peninsula. We discovered a pair nesting in the brick chimney of the keeper's cabin at Breakwater in July, 1927.

Archilochus colubris. Ruby-throated Hummingbird.-First noted on May 9, 1928, which date is probably close to the usual spring arrival date for the species according to our knowledge of its appearance in contiguous areas. Humming-birds were observed regularly throughout the spring periods spent on Long Point, but they were noted irregularly in summer. Records from the mainland indicate that it is regularly distributed there in summer.

ㅇ. June 2, 1927

Tyrannus tyrannus. KING-BIRD.-Our earliest arrival date for this species is May 6, 1928, king-birds being present in numbers from that date on. A migration date for the fall was obtained from the casualties at the lighthouse on September 7, 1929 (Saunders, 1930) when two were killed. It is a fairly common summer resident of Long Point and vicinity. Several nests were found during the summer at various parts of the point, in apple (escaped), sycamore, and willow trees, from eight to fifteen feet from the ground. 
Myiarchus crinitus. Crested Flycatcher.-First recorded in 1928 on May 4. Their numbers during the migration season did not exceed those of summer at which time it was observed regularly and not uncommonly. We secured evidence that it is a breeding bird on the peninsula and it undoubtedly nests on the adjacent mainland also since it occurs throughout that area in summer.
$0^{7}$ May 15,1928
९ May 27,1927
$\sigma^{7}$ June 2,1927
व June 24,1927

Sayornis phœbe. PheBe.-This early migrant was present on our earliest arrival in the region, April 30, 1928, and it occurred casually as a migrant until the middle of May of that year. One was killed by the Long Point light on September 7, 1929 (Saunders, 1930). It is a fairly common nesting bird on the mainland, but on the point it is rare in summer; the latter area, probably does not offer many suitable situations in which to nest. We found one nest in a small, dilapidated building at Breakwater in 1927 .

이 May 2, 1928

Nuttallornis borealis. Olive-Sided Flycatcher.-Apparently a rare migrant in the region. Two were seen on May 30, 1927, one of which was collected.

○ May 30,1927

Myiochanes virens. Wood Pewee. - Not seen by us until May 19 in 1928, although we visited wooded areas on several occasions prior to that date; an earlier record (about May 14) was obtained from the casualties at the Long Point light. They had arrived in numbers by May 27 (1928). Casualties at the Long Point light in 1929 give fall migration dates between September 7 and September 29 (Saunders, 1930).

Wood pewees are one of the most common summer resident and nesting birds on Long Point. Taverner (1914) has noted a similar status on the peninsula of Point Pelee.

$$
\text { ơ May 27, } 1927 \text { ○’ July 4, } 1927
$$

Empidonax flaviventris. Yellow-Bellied Flycatcher.-The earliest arrival date is about May 14 (lighthouse casualties) 1925, and the latest spring record was made on June 1, 1924, by Mr. W. E. Saunders. Although we identified only six of these birds in spring, the information secured as a result of casualties at the lighthouse and observations of Mr. Saunders indicate that this flycatcher occurs not uncommonly in spring. The only information concerning its southward flight is from a specimen killed at the light on September 25 or 26, 1929 (Saunders, 1930). This specimen, which is now in the R.O.M.Z. collection, exhibits yellowish buff tips to the greater and median wing coverts, a character 
usually attributed to the juvenile plumage but which may also be possessed by adults in their winter plumage.
万’ May 27, 1927
ㅇ May 30,1927

के June 2,1927

? Sept. 25 or 26,1929

Empidonax virescens. ACAIIAN Flycatcher.--Two flycatchers killed by the Long Point light about May 14, 1925, were examined by Mr. W. E. Saunders on June 7. Needless to say the specimens could not be preserved, but Mr. Saunders determined these birds as Acadian flycatchers and they were recorded as such by Lewis (1927b).

Empidonax trailli alnorum. Alder FlycATCHER.-At least two alder flycatchers were picked up after a destruction which occurred at the Long Point light about May 14, 1925. The majority probably come northward after that date, but we did not see the species during either one of the periods of our stay on the point. Some migratory dates for the fall are indicated by specimens which struck the light on September 7 , 1929 (Saunders, 1930). A specimen in the collection of Mr. W. E. Saunders was secured from the casualty of September 25 or 26, 1929.

One of those puzzling individual specimens so well known to ornithologists is represented in the Museum's Long Point collection. The measurements of the specimen, a male, are as follows: Weight, $117 \mathrm{gms}$; length, $141 \mathrm{~mm}$; wing, $66 \mathrm{~mm}$; tail, $59 \mathrm{~mm}$; culmen, $11 \mathrm{~mm}$. This individual has been named $E$. trailli alnorum, although it is recognized that the size is small-within the range of males of E. minimus.
\% September 7, 1929
Im. ठ7 September 7, 1929

Empidonax minimus. LEAST Flycatcher.-First noted on May 3, 1928, when four individuals were seen. This appears to be a fairly early arrival date. It was seen regularly from that date on throughout May of that year being at its height in numbers between May 17 and 22 during which time it was a common bird. Our latest spring migration date is June 14,1927 . For some unknown reason the species is virtually absent from the point as a summer resident. One was noted on July 16, 1927, and again on July 23, but these were considered early returning migrants or wanderers, since the species had not been seen for over a month although we had been encamped during most of that period in an area apparently suited to them. We have no record of its occurrence in summer on the adjacent mainland, but it may be present in spite of the fact that we did not see it about Port Rowan in 1927. Mr. R. V. Lindsay did not observe it at Fisher's glen in July, 1927, and no summer occurrences on the mainland have been noted by Mr. W. E. Saunders. Casualties at the Long Point light present a late fall migration date, four least flycatchers having been destroyed there on September 7, 1929. A note of possible interest concerns the 
bird collected on July 16. It was uttering the characteristic "chebec" and proved to be a female.

ㅇ May 26, 1927

ㅇ July 16,1927

Octocoris alpestris praticola. Prairie Horned LARK.- $\mathrm{Mr}$. W. E. Saunders has recorded the prairie horned lark in his personal notes made at Turkey Point (May 17, 1925), at the base of Long Point (May 30, 1908) and at Port Rowan (May 31, 1908), from three to six having been noted on each of these days. Mr. W. E. Clyde Todd also noted the species once at the base of Long Point and twice on the mainland near Port Rowan in July, 1907. We have no records concerning the species in other seasons within the area.

Cyanocitta cristata cristata. BluE JAY.-A rare summer resident of Long Point but more numerous on the mainland. On May 22, 1928 , we saw four blue jays on Ryerson's island, a restricted area which was not occupied by this species during the previous summer. These birds were probably wanderers or migrants and the example is an excellent one to show the advantages of making observations on moving birds in an isolated and restricted area where a knowledge of summer resident species has previously been obtained.

우 May 12, 1928

Corvus corax principalis. NORTHERN RAvEn.-A very early record for the species has been made by Durand (1897) who remarks on its occurrence at Long Point about the year 1827. A specimen taken locally about thirty years ago is now in the collection of Mr. Wm. Smith of Port Rowan. An illustration of the raven is among the Pope paintings (Locke, 1917) and is dated November, 1859.

Corvus brachyrhynchos brachyrhnchos. Crow.-A common species throughout the region. We usually found it nesting in the evergreens in the woods on the point in 1927 . One nest was situated fifteen feet from the ground in a lone red cedar tree which stood in an exposed situation on top of the sand dune, bordering the south beach. Judging by the situation, the parent birds depended on the open beach for much of their foraging for food. Four well grown young occupied the nest at the time, June 27.

On July 4, 1927, the writer discovered the tracks of crows leading from one excavated turtle nest to another. The evidence was that the crows followed up the depredations of carnivorous mammals, a fox in the present case, and salvaged the remains of turtle eggs left by these animals.

An amusing incident illustrating something of the character of crows was observed by the writer on May 10, 1928. While well concealed in a reed blind on the sand bar of Second island I watched a pair of crows 
come over and settle within fifteen feet of the blind. Apparently any suspicion of the blind itself had long since been allayed because of its long standing in this situation. As the birds walked about they exhibited that careful and at the same time careless dignity possessed by crows, feeding at times on the carcass of a dead fish at the water's edge. At first I remained motionless, fearing that a sound from the blind would send them off in haste. However, the sound of slight movements in the dry reeds inside my shelter did not particularly attract their attention. I then attempted to experiment with their nerves to ascertain whether certain movements might be interpreted as due to the presence of danger. I stuck a stiff, dry stalk of rush through the top of the blind which was open, and rattled it fiercely. The crows cocked their heads on one side and eyed this unusual occurrence skeptically, but did not appear alarmed. The same thing was repeated but their reaction was that of little interest. I whistled various bird-calls from the blind. They were mildly interested but not alarmed even at my poor imitations. Presently, while I was thinking of what to do next, a small band of yellowlegs came over. I had been hoping for these and instantly rose to my feet with head and shoulders out of the blind and fired at the nearest yellowlegs. The surprise to the two crows must have been great. When I turned, they were dashing away across the marsh in a direct, silent and speedy manner. After getting perhaps a hundred yards distant (out of gun range!) their voices broke out in loud staccato cries, seeming to proclaim to the world the closeness of their escape and also to explain by what courage and generalship they had avoided danger.

$$
\text { Juv. व7 June 21, } 1927
$$

Sturnus vulgaris. Starling.-Established on Ryerson's island as a nesting species in 1927. Also known to be generally distributed along the adjacent mainland. The species probably invaded the general region for the first time in 1921 (Lewis, 1927a), but was not recorded from there until 1923.

From July 1 to the end of our stay in 1927 we noted flocks of starlings making daily trips eastward along the point in the early morning and back again in the evening. They appeared in specific flocks or associated with grackles and red-winged blackbirds. From nine to sixty were noted on several of the occasions on which we attempted to determine the starling numbers in these blackbird flocks.

Juv. ? May 30, 1927

Dolichonyx oryzivorus. BoBolink.-Bobolinks are common birds in summer on the adjacent mainland, but they apparently do not find suitable nesting grounds on the point. Their spring migration was under way on Long Point on May 4, 1928, and did not cease until May 25. A usual date of arrival in spring is probably about the first 
of May. Macoun (1898) records the species as having been seen on Long Point on June 13, 1898. Bobolinks may have been resident on the point at that date, or the observation may have concerned wandering birds. The earliest southward movement in the summer of 1927 was noted on July 11, two having been seen, after which they became increasingly conspicuous. Flocks visited the wet, grassy flats of Long Point to feed. These birds were too wild to be easily collected so that we had little success in attempting to get males in changing plumage, but the one we did secure showed some replacement of nuptial dress in the ventral tracts and in the crown, interscapulars, and the greater wing coverts. The two females secured did not show obvious replacement.

Late fall dates are available through records of casualties at the lighthouse. Thirty-two bobolinks were destroyed there on September 7 , five on September 9 and one between September 24 and 29, 1929 (Saunders, 1930).

$$
2 \text { ㅇ's July } 21,1927
$$$$
\text { o' July } 23,1927
$$

Molothrus ater. CowBIRD.-A common migrant in spring and a fairly common summer resident of the point and adjacent mainland. The earliest available spring record is April 17 or 18, 1930, a bird having been killed by the Long Point light at that time, but it doubtless appears in the region two or three weeks earlier. Judging from our knowledge of its appearance in contiguous areas, it perhaps usually arrives the first week of April.

$$
\sigma^{7} \text { June 8, } 1927
$$

Juv. 우 June 29,1927

Agelaius phœniceus phœniceus. RED-WINGED BlACKBIRD.The species doubtless arrives in early March in this region. It was present in numbers on April 30, 1928. It certainly appears to be more common and generally distributed in spring than in summer, perhaps due to the presence of transient individuals as well as those which will remain to nest, and also because nesting concentrates these birds into certain chosen sections of the extensive marshes, large and small, of the point and mainland. Nests with full complements of eggs are to be found by mid-May, but the majority of redwings appear to nest somewhat later than that, and it seems apparent that two broods are reared in this region. Two interesting nests of this species were found in 1927. One was somewhat out of the ordinary since it was situated in the crown of a hummock of grass on a rather dry section of Snow island, somewhat removed from the marsh, and apparently it stood alone rather than with others. The other, which was at least unusual for Long Point, was situated five feet up in a dog-wood shrub in a wet section of fairly dense woods on Ryerson's island. Red-winged blackbirds usually place their nests in rush or reed beds in the marshes of this region. 
This species congregated in flocks by July 1, 1927, and was observed making daily visits toward the end of Long Point. These flocks could be seen flying eastward over our camp in the early hours of morning, flock after flock coming from the direction of the main marsh, west and north of Courtright ridge, and going out of sight to the east. In the evening between six and eight o'clock they returned. The whole flight, taking place in a spasmodic fashion, would require an hour or so to pass. We could not ascertain from whence these birds came or where they were going, but it would appear that birds from the main marsh and from the marshes on the mainland collected and scattered over the smaller marshes toward the end of the point to feed during the day. At night they probably sought some part of the main marsh in which to roost.

Our use of reed or rush blinds proved a method unequalled from the standpoint of watching birds at close quarters. Incidental observations were made in this way which gave one a true picture of the natural behaviour of many species. Even the common red-winged blackbird became a new study under such conditions. The writer observed this species for a considerable time at a distance of no more than three feet and saw with what dexterity they used their bills in searching for food. Bits of debris were "rooted" over or pushed to one side, these objects being turned and moved with ease during the birds' minute search for acceptable morsels. One bird attempted to bath in a small pool near the blind but found the water beyond the ideal depth for the performance. Reaching up, it grasped a small willow sprout in its bill and drew it over. In an instant the bird was perched upon the recumbent sprout, and finding its elevation to be satisfactory, proceeded to dip and wet its plumage. The alternate dipping, spattering, fluffing and preening were all carried on within arms-length of the writer's face.

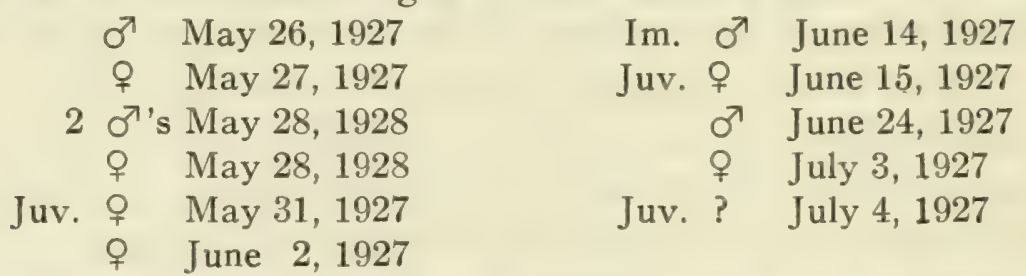

Sturnella magna magna. MEADOWLARK.-A rare summer resident on Long Point, but fairly common on the adjacent mainland. We found at least two pairs, with broods of young, which were certainly established on the point. These were found in an extensive burnt and cleared area near the Bluffs. The species was observed, however, on the point near the base in a comparatively dry area bordering the marsh, on July 19, 1927. It may have been established there.

On July 17, 1927, a meadowlark was observed in a large flock of redwinged blackbirds flying over our camp on Courtright ridge. 
Icterus spurius. ORCHARD OrIOLE.-Nash (1908) states that he found the species regularly in Norfolk county. It is established more or less irregularly on the mainland adjacent to Long Point, Mr. W. E. Clyde Todd noting it as numerous about orchards and shade trees near Port Rowan in 1907. Apparently it occurs only as a migrant on the point. It is a late migrant according to our records. Mr. W. E. Saunders noted it at Port Rowan on May 31, 1908, and we collected a specimen on June 2, $1927 . \quad \sigma^{7}$ June 2, 1927

Icterus galbula. BALTIMORE ORIOLE.-Our earliest record concerning the arrival of this species in spring was May 7, 1928. It did not appear in numbers, however, until the middle of the month. It is a common nesting bird on the point and the adjacent mainland, from one to ten having been seen daily during the summer of 1927 .

$$
\begin{array}{lll}
0^{7} & \text { May 31, } 1927 & \text { Juv. ? July 8, } 1927 \\
\text { o } & \text { May 31, } 1927 &
\end{array}
$$

Euphagus carolinus. Rusty BLACKBIRD.-Four rusty blackbirds were killed by striking the Long Point light on April 17 or 18, 1930, and two were destroyed there on April 20 or 21 of the same year. The species probably arrives somewhat earlier than these dates indicate and their flight probably continues throughout April. We did not record the species during our visit there in the spring of 1928 (April 30 and through May). No information is available relative to the species in the fall.

Quiscalus quiscula æneus. Bronzed Grackle.-A common migrant and also a fairly common nesting species on Long Point and the adjacent mainland. We found it nesting on a few occasions and it is apparent that the species prefers vine-covered trees in this region. Grackles appeared in flocks during the first week of July, 1927, and were noted in great numbers, as described elsewhere in this paper in connection with the red-winged blackbird. Sometimes grackles were associated with the red-wings in flocks. These flocks doubtless increase in numbers as the fall approaches. Mr. Saunders estimated the numbers in a flock at five thousand, the observation having been made on August 25, 1918, at Port Rowan.

$$
\begin{aligned}
& \text { Juv. OT May 27, } 1927 \\
& \text { q June } 7,1927 \\
& 2 \sigma^{77} \text { 's June 8, } 1927 \\
& \text { Juv. } \begin{array}{ll}
\sigma^{7} & \text { June } 8,1927 \\
\sigma^{7} & \text { June 14, } 1927
\end{array}
\end{aligned}
$$

Carpodacus purpureus purpureus. PurPle Finch.-A specimen forwarded to the Museum by Mr. Munroe Landon, in November, 1929, had been picked up dead on the shore of Long Point bay. The bird which was in good condition was preserved and is now in the Museum's collection. It is our only record for the region. 
Loxia curvirostra minor. CrossBrlL.-A specimen of this species was picked up on the roadway near Turkey Point on May 10, 1931, by Mr. R. V. Lindsay. The bird had been badly damaged by motor cars but diagnostic parts are preserved in the Museum's collection and it constitutes our only record of the species for the region.

\section{? May 10, 1931}

Passer domesticus. House Sparrow.-This species does not find suitable territory on the point except at the extreme end where the habitation of the lightkeeper and other buildings afford it a habitat. On May 2 and 5, 1928, we observed this species on Second island, and once again on May 18. These few individuals were wanderers since they were not seen there again nor had they been observed there during the summer of 1927. House sparrows are, of course, plentiful about towns and farmhouses on the mainland.

\section{우 July 19,1927}

Astragalinus tristis tristis. GoldFinch.-First noted by us on May 9, 1928; a week later it had become quite common and of regular occurrence. It is not an uncommon nesting bird on the point and on the adjacent mainland, where it is equally, if not more numerous.

$$
\text { 우 June 2, } 1927 \text { 万 June 25, } 1927
$$

Poœcetes gramineus gramineus. VESPER SPARRow.-Three vesper sparrows struck the lighthouse on April 17 or 18, 1930. We were present early enough to obtain a late spring migration date for this species in 1928, the date being May 3, one bird having been collected. So far as we could ascertain this sparrow does not now inhabit the point in summer, but it is a common bird of the adjacent mainland. Macoun (1898) however, notes the species as having occurred on the point on June 21, 1898. Mr. R. V. Lindsay found two nests with four and three eggs respectively during the first two weeks of July, 1927, at Fisher glen.

\section{우 May 3, 1928}

Passerculus sandwichensis savanna. SAvannah Sparrow.This species which normally arrives in southern Ontario in early April was still to be found as a migrant on Long Point in May, 1928, the last having been noted on May 21. Savannah sparrows are regularly destroyed by the Long Point light in the spring and in the fall. Fortyfour were noted by $\mathrm{Mr}$. Lorne Brown, the present keeper, which had been killed between April 17 and 19, 1930, and eighty-three were destroyed between September 24 and 29, 1929. The point apparently does not offer suitable habitat for this species except at the base, but it is a common summer resident of the adjacent mainland.

An adult male specimen killed at the Long Point light on September 25 or 26,1929 , is of interest. It is a large, dark bird which shows white 
on the lores and along the superciliary stripes rather than yellow, and there is remarkably little buff in the plumage for the season. The measurements of this specimen are as follows: weight, $21.7 \mathrm{gms}$; length, $155 \mathrm{~mm}$.; wing, $75 \mathrm{~mm}$.; tail, $61 \mathrm{~mm}$.; culmen, $10.5 \mathrm{~mm}$.

\begin{tabular}{|c|c|c|c|}
\hline 우 & May 3, 1928 & $2 ?$ & Sept. 25 or 26,1929 \\
\hline 우 & May 17,1928 & Im. $\sigma^{x}$ & Sept. 25 or 26,1929 \\
\hline$\sigma^{7}$ & Sept. 25 or 26,1929 & $2 \mathrm{Im} . ?$ & Sept. 25 or 26,19 \\
\hline
\end{tabular}

Ammodramus savannarum australis. Grasshopper Sparrow -The earliest arrival date for this species is May 14, 1925, a bird having struck the Long Point light on that date. We secured a specimen on May 17, 1928. A fall date is given by Saunders (1930) who records a specimen which struck the light between September 24 and 29, 1929.

During the summer of 1927 we made on observation which seemed to suggest that this species was established one the point. On June 14, Mr. Baillie and the writer observed a sparrow in an open glade in the woods of Ryerson's island which, although it could not be collected, appeared to both of us as being of this species. Mr. W. E. Clyde Todd noted one in the region during July, 1907. It is known to be established in summer at Fisher glen where it was observed by Mr. W. E. Saunders on July 21,1927 , and also on a number of occasions by Mr. R. V. Lindsay during July of the same year.

\section{$\sigma^{7} \quad$ May 17,1928}

Passerherbulus henslowi henslowi. Henslow's Sparrow.-Although the form occurring at Long Point is probably referable to occidentalis, material for comparison has not been available. The name $P . h$. henslowi has therefore been used provisionally and is in accord with the stated distribution of forms in the 1910 edition of the A.O.U. Check List.

An extensive colony of this species was established in the wet, grassy flats between Courtright ridge and Squire's ridge during the summer of 1927. Examination of specimens collected, and an observation made by Mr. Baillie on July 14, when a bird was seen carrying some material in its beak, leaves no doubt that these birds were nesting there, but we were unsuccessful in finding a nest in the limited time for such work. The opportunity of observing this sparrow in a characteristic summer habitat was full of interest. Its simple song, "tsr'slick", and brief, deceptive, butterflylike flight, when heard and seen for the first time, or at least on rare occasions, constitute a memorable experience.

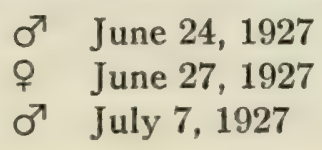

13 -
万 July 14,1927

2 ठ's July 23, 1927 
Zonotrichia leucophrys leucophrys. WhITE-Crowned SpARrow. -. The date of the earliest arrival of this sparrow so far as ascertained is April 18 or 19, 1930, a specimen having struck Long Point light at that time. Our earliest record in 1928 was made on May 3. Only a few birds were noted on that date but by the middle of the month they became more numerous; in fact, on May 15, they were recorded on our charts as "very common", a status accorded few species. The spring migration continued until May 21, three birds having been noted by us on that date. In the fall we have but a single record, that of Saunders (1930) who lists seventeen specimens killed at the light between September 24 and 29, 1929.

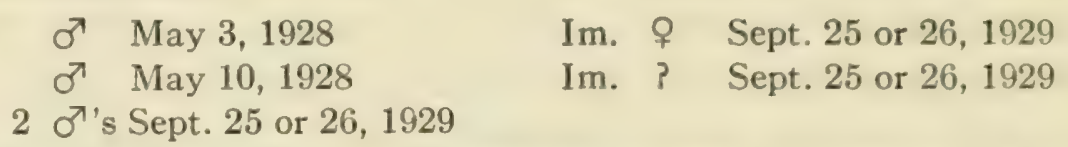

Zonotrichia albicollis. White-throated Sparrow.-A single white-throat was picked up at the lighthouse by Mr. Lorne Brown after a destruction of birds there on April 17 or 18, 1930. Three others were found which had been killed on April 18 or 19. It doubtless appears in increasing numbers, reaching its height about May 19 according to our observations in 1928. This date is about one week earlier than that on which the white-crowned sparrow reached its maximum numbers. Their migration is practically over by May 18 , but we saw individual birds on May 22 and May 27, 1928. A fresh specimen was washed up on the beach on May 31, 1927.

An unusual record of a singing white-throat was made on July 16, 1927. The bird was heard and seen in the woods on Courtright ridge but we were not fortunate enough to secure it. This occurrence in midsummer is of particular interest since the individual was considerably astray from a known breeding area and was apparently in normal physical condition. White-throats migrate southward in numbers during September and sixteen were destroyed at the lighthouse on September 24 or 25, 1929 (Saunders, 1930).

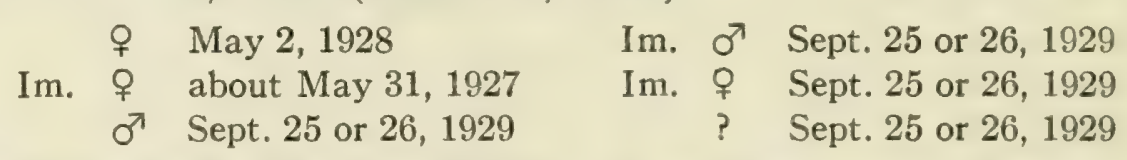

Spizella monticola monticola. Tree Sparrow.-Tree sparrows had largely passed northward at the time of our earliest arrival in the region, April 30, 1928. Although we noted them as fairly common on May 2, no others were seen after that date. The earliest record has been obtained from lighthouse casualties, four having been destroyed there on April 17 or 18, 1930. We have no information relative to the occurrence of the species in the region in fall or winter. 
Spizella passerina passerina. ChIPPING SParrow.-The spring movement of this species was largely concluded by the end of April in 1928 , but we noted one bird on May 3 which was evidently a migrant. It is one of the most common breeding birds of the wooded parts of Long Point and also of the adjacent mainland.
$0^{7}$ May 3, 1928
or June 4, 1927
2 juv. ㅇ's July 4, 1927

Spizella pusilla pusilla. Field Sparrow.-We were not successful in discovering this species established on Long Point in summer, but it is to be found sparingly on the adjacent mainland. A migrant individual was observed on May 1 and two were noted on May 10 in 1928.

$$
\sigma^{7} \text { May } 10,1928
$$

Junco hyemalis hyemalis. SLATE-COLORED Junco.-A common migrant, still present in numbers when we arrived in the region in 1928. It was common until May 4, after which its numbers dropped rather abruptly, the last normal migrant having been noted on May 9. An injured bird was secured as late as May 27, in 1927. Their northward movement in April has been shown by casualties at the lighthouse, fourteen having been killed on April 17 or 18, seven on April 18 or 19 and eight on April 20 or 21, 1930. Unfortunately we have no information concerning the junco in fall or winter.

$$
\text { 우 May 2, } 1928 \text { 은 } \operatorname{May} 27,1927
$$

Peucæa æstivalis bachmani. Bachman's SparRow.-A female collected on Ryerson's island on May 6, 1928, is apparently the second specimen taken in Canada (Snyder, 1929). This record was one of the surprises of bird collecting on the point and such records hold considerable interest. If individuals of typically southern forms, through some cause or another, overfly their mark in migrating northward, they probably fail to establish themselves as resident species in most cases. But if conditions are suitable, and individuals of both sexes find themselves in new territory at the breeding season, they may establish themselves temporarily or for an extended period. Such might be the case with Bachman's sparrow in the Long Point region. The changing physical conditions through advancing civilization are undoubtedly making possible acquisition of new territory on the northern periphery of the range of several species.

우 May 6, 1928

Melospiza melodia melodia. Song Sparrow.-It was difficult to detect migratory movements in this species since it arrives much earlier than our records start. It probably arrives in March. Two April records are given among lighthouse casualties-one bird killed on April 18 or 19 and two killed on April 20 or 21, 1930. This latter record 
indicates that the species is still on the move through the region at a date near that of our arrival, April 30 (1928), and our observations on Second island, where estimates of population could be fairly accurately made, indicated that the song sparrow population did not drop to summer numbers until the second week of May. This lessening of individuals observed was apparently not associated with nidification duties which requires the more or less inactivity of one half of the resident population, since a further reduction, attributed to this cause, was noted about May 21. Further evidence was secured on this latter point by finding an incomplete set of three eggs of the species, the first noted in 1928, on May 18. This nest was of interest as regards its location since it was placed in a loose roll of dry nightshade vines which had been left exposed on the bare mud flats near Second island, presumably by the wind and waves which scoured the marsh on December 8, 1927. The song sparrow is a common nesting species in suitable situations on the point and adjacent mainland.

Our collection of skins exhibits a marked uniformity and the birds are by comparison identical with those found in southern Ontario generally.

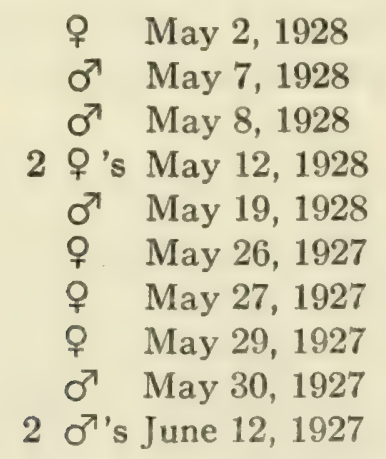

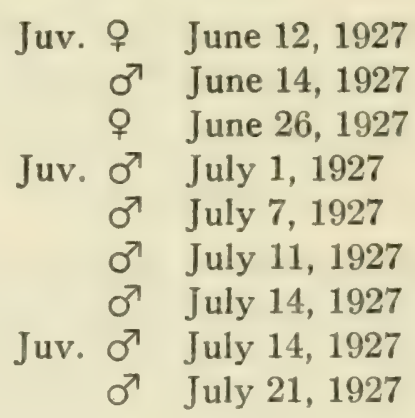

Melospiza lincolni lincolni. Lincoln's Sparrow.--Our records of this species in 1928 are perhaps worthy of complete enumeration since Lincoln's sparrow is rarely seen during migration in southern Ontario. A single bird was noted on May 17, six on May 18, three on May 19, four on May 20, two on May 21 and four on May 22. These observations were all made on Second and Ryerson's islands. The dates probably set the usual time of spring occurrence of the species in this region, although an earlier date is shown by lighthouse casualties, two having been destroyed about May 14, 1925 (Lewis, 1927b). Fall migration dates are shown by the destruction of two on September 9, 1929, and ten between September 24 and 29 of the same year (Saunders, 1930).

$$
\begin{array}{llll}
\sigma^{7} & \text { May 17, } 1928 & \sigma^{\top} & \text { May 22, } 1928 \\
\text { ᄋ } & \text { May 21, 1928 } & \text { क } & \text { about Sept. 26, } 1929
\end{array}
$$

Melospiza georgiana. Swamp Sparrow.-This species probably arrives in early April, but our earliest record is of three birds killed at the 
lighthouse on April 17 or 18,1930 . We noted it fairly commonly in May, 1928, until the 18th, in situations that suggested that these birds were still moving through the region. Substantiation of this is given by the destruction of three birds, undoubtedly migrants, at the lighthouse on May 19, 1926. The species is not a plentiful summer resident, but Mr. W. E. Saunders has noted it at Turkey Point in the breeding season and we found a few here and there on Long Point where it breeds. A fall date of migration is given by lighthouse casualties, three having been killed between September 24 and 29, 1929 (Saunders, 1930).

$$
\sigma^{\top} \text { June 12, } 19272 \sigma^{71} \text { 's June 24, } 1927
$$

Passerella iliaca iliaca. Fox SPARRow.-Fox sparrows probably pass through the Long Point region in the greatest numbers in early April. Twenty struck the lighthouse on April 17 or 18, eight on April 18 or 19, and four on April 20 or 21, 1930. We found stragglers passing through at the time of our arrival there on April 30, 1928, the last record being of an individual collected on May 4. We have not been able to secure accurate information relative to the occurrence of the species in the region in the fall.

$$
\text { 우 May 2,1928 ? May 4, } 1928
$$

Pipilo erythrophthalmus erythropthalmus. TowHeE.-This early migrant was still on the move in May, 1928, and we recorded a few regularly until past mid-May, the last - two birds-were seen on the twentieth. It is an extremely rare summer resident of the point, only two having been seen in 1927, but it is not uncommon on the adjacent mainland. Mr. R. V. Lindsay found a nest with four eggs at Fisher glen in July, 1927.

$$
\text { 万ั June } 12,1927 \text { ㅇ July } 8,1927
$$

Cardinalis cardinalis cardinalis. CARDINAL.-This species has not found suitable conditions on the point proper, probably because of the absence of thickets and vines for cover, but at least one pair was established on Ryerson's island where undergrowth is plentiful. Conditions on the adjacent mainland are apparently more suitable, since it has increased during the past few years. Mr. Angus Buchanan who has made yearly trips to Fisher glen has informed the writer that in April, 1922, he saw one cardinal. Annual visits were made at the same season and the number of cardinals seen increased, twenty-five having been noted in April, 1929. Mr. R. V. Lindsay also observed a number of them at Fisher glen in July, 1927, and found a nest there and $\mathrm{Mr}$. W. E. Saunders has seen the species at Turkey Point and at Port Rowan. 
Hedymeles ludovicianus. Rose-Breasted Grosbeak.-First noted as a migrant on May 12,1928, after which it was seen regularly, but rather uncommonly, until May 22. Representatives of this species have been destroyed by the light between these spring dates. A bird seen on Ryerson's island, May 30, 1927, may have been a migrant or established as a summer resident bird. It was not noted on the point again in the summer of 1927. It is apparently not numerous as a summer resident species on the mainland, but Mr. W. E. Saunders has noted it at Port Rowan. Four were destroyed at the lighthouse during their souther migration between September 24 and 29, 1929 (Saunders, 1930).

$$
\begin{aligned}
& \text { 이 May 17, } 1928 \text { 우 about Sept. 26, } 1929 \\
& \text { के May 18, } 1928
\end{aligned}
$$

Passerina cyanea. Indigo Bunting.-First noted as a migrant on May 20, 1928. The species is not an uncommon breeding bird on the point, but it is more common on the mainland. The sparseness of undergrowth is probably a controlling factor in their numbers on Long Point. One nest found on Courtright ridge was situated two feet from the ground, attached to thistle and fireweed stalks, the only available cover in the vicinity. This nest contained three newly-hatched young and one egg on July 12, 1927. Mr. R. V. Lindsay found the species nesting in dwarf juniper at Fisher glen in July, 1927. Indigo buntings are moving southward in late September as attested by lighthouse casualties (Saunders, 1930) five having been picked up after destructions between September 24 and 29, 1929.

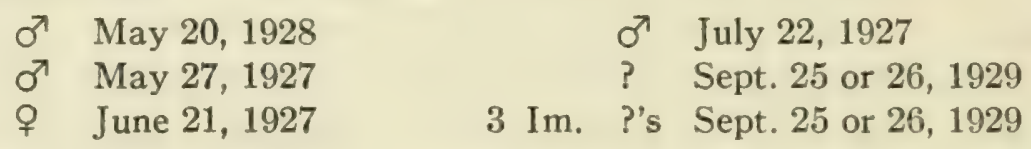

Piranga erythromelas. ScARLET TANAGER.-The earliest arrival date in the available records is about May 14, 1925. Fifteen specimens of this species were destroyed by the light at that time. Two were seen at Turkey Point on May 17, 1925, by Mr. W. E. Saunders. They occur regularly as migrants on the point until May 27, one having been noted on that date in 1927. Transient individuals are probably present in the region until the first of June. The species is to be found in certain areas of the adjacent mainland in summer, but not on the point. A similar distribution exists in the Point Pelee region according to Taverner (1914). Mr. R. V. Lindsay noted several at Fisher glen in July, 1927. A scarlet tanager was destroyed at the lighthouse on September 7, 1929, and fourteen others were killed between September

\begin{tabular}{|c|c|c|c|}
\hline$\sigma^{\pi}$ & May 22,1928 & 우 & Sept. 25 or 26,1929 \\
\hline 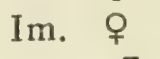 & Sept. 7, 1929 & Im. & Sept. 25 or 26,1929 \\
\hline$\sigma^{7}$ & Sept. 25 or 26,1929 & Im. ? & Sept. 25 or 26,1929 \\
\hline
\end{tabular}
24 and 29 of that year. 
Progne subis subis. Purple Martin.-This early migrant was present in numbers at Port Rowan when we arrived on April 30, 1928, and we were informed that it had returned about the first of April that year. Mr. J. Biddle of Port Rowan stated that it usually returns early in the second week of April. Although we saw a few martins regularly throughout both periods of our stay on Long Point we had no reason to suspect that the species nested elsewhere on the point than at "The Cottages", where nesting boxes have been provided. The species nests commonly about Port Rowan and also at other settlements along the adjacent mainland shore.

or May 26, 1927

Petrochelidon lunifrons lunifrons. ClifF Swallow.-The earliest record for the area is that of Macoun (1898) who recorded this species at the point on June 3, 1898. Mr. W. E. Clyde Todd saw several around Port Rowan in July, 1907, and on July 13 he records having seen an adult bird feeding a young one east of the town. The species does not appear on any of the lists made by Mr. W. E. Saunders during his several visits to the region, and our party did not note it in 1927 or 1928. It may, however, still be present as a summer resident of the region although the species is more or less subject to a fluctuation or general reduction of numbers.

Hirundo erythrogastra. BARN Swallow.-A common breeding bird of the region. Isolated pairs nest about buildings on the point and occur in greater numbers on the adjacent mainland. Barn swallows appeared to be more common on the point after the first of July when young birds that had left the nest became conspicuous as they foraged over the open expanse of marsh.

$$
0^{7} \quad \text { May } 27,1927
$$

Iridoprocne bicolor. TREE Swallow.-An early migrant which reached the region of Long Point in spring prior to our earliest arrival, April 30, 1928. Numbers remain in the district to breed, and we found them well distributed throughout the area. They are seen in the greatest numbers after the first of July when small open flocks begin to appear. As the season advances their numbers are augmented by new broods and perhaps by birds from adjacent territory.

$$
\sigma^{7} \text { May 31, } 1927 \text {. Nestling o June 21, } 1927
$$

Riparia riparia. BANK Swallow.-The earliest record was made on May 1, 1928, when one bird was noted. A few were seen on May 5 after which they were of regular occurrence, increasing in numbers up to May 26, a date when they were "very common". The species is present in numbers throughout the summer. They nest in suitable situations in the sand banks bordering the south beach of Long Point and in certain 
places on the mainland. Mr. R. V. Lindsay found them nesting in hundreds at Fisher glen in 1927. Flocks congregate during the first week of July, the number and compactness increasing as the season advances. On July 12, 1927, Mr. Baillie and Mr. Edmonds observed an enormous flight of these birds near Second island. The flock, estimated at twenty thousand birds, was trying to proceed northward against a strong gale which was blowing across the bay. They flew in a long, dense flock and although they made poor headway against the storm, they fought it out on the wing, the flight having been in sight for fully half an hour.

$$
\text { ơ June 4, } 1927
$$

Stelgidopteryx serripennis. Rough-winged Swallow.-Our only records for this species were obtained from the notes of Mr. W. E. Saunders, who saw two birds at Turkey Point on May 17, 1925, and nine on Long Point on June 1, 1924. It is quite probable that the species is established in the region as a regular summer resident.

Bombycilla cedrorum. CEDAR WAXWIng.-Although this species probably occurs throughout the year in the Long Point region, we did not see it in May, 1928, until the fifteenth. It was observed moving about in flocks throughout the first two weeks of June, 1927. It became more settled after that date. A few were noted daily for the remainder of the summer.

$$
\begin{array}{ll}
8^{7} & \text { June } 8,1927 \\
\$ & \text { June } 8,1927
\end{array}
$$

우 June 12,1927

Lanius ludovicianus migrans. Migrant Shrike.-Not seen by us on Long Point and apparently scarce on the mainland. Mr. W. E. Saunders noted one at Turkey Point on May 17, 1925.

Vireosylva olivacea. RED-EYED VIREO.-Our earliest record was made on May 14, 1925, thirty-two birds having been destroyed on that date at the Long Point light (Lewis, 1927b). We noted it as a migrant on May 19, 1928, and again on May 22, the latter date probably being near the close of their northward spring movement. This vireo is one of the common summer residents of the point and adjacent mainland. We found it nesting in the lower branches of sugar maples and also in witch-hazel shrubs. The species migrates through and from the region during September, one hundred and nine having been picked up about the Long Point light after the destruction of September 7, twenty-six on September 9 and forty-one between September 24 and 29, 1929 (Saunders, 1930). 
Vireosylva philadelphica. Philadelphia Vireo.-Fourteen individuals of this species were destroyed by the Long Point light on May 14, 1925 (Lewis, 1927), this being our earliest date for the species in spring. A specimen collected on Ryerson's island on May 22, 1928, and one collected on May 27, 1931, at Turkey Point by Mr. D. A. MacLulich, give us our only spring records other than the above. This vireo migrates southward in September, one having been found at the foot of the lighthouse after the destruction on September 7 , one on September 9, and two between September 24 and 29, 1929 (Saunders, 1930). This vireo is apparently a rather plentiful transient in the region.

$$
\begin{array}{llll}
0^{7} & \text { May 22, } 1928 & \text { ? } & \text { Sept. } 25 \text { or } 26,1929 \\
\text { ? } & \text { May 27, } 1931 & &
\end{array}
$$

Vireosylva gilva gilva. WARBLING VIREO.-On May 5, 1928, the writer, while employed within a camp building on Second island, heard the warbling song of a bird outside and my first impression was that it was the song of a purple finch. When I reached the outside, however, the bird had disappeared, but the sound was still vivid in my mind and I realized that I had been listening to a warbling vireo. Mr. W. E. Clyde Todd noted quite a number of warbling vireos about Port Rowan in July, 1907. We did not see it on the point during the summer of 1927.

Lanivireo flavifrons. Yellow-Throated Vireo.-Mr. W. E. Clyde Todd saw a yellow-throated vireo near Port Rowan on July 15, 1907. Our only observation of this species was that of a bird seen on Ryerson's island on May 30, 1927. Our knowledge of the general distribution of this species in southern Ontario suggests that it should be found as a more or less rare summer resident in the region.

Lanivireo solitarius solitarius. BLUE-HEADED VIREO.-Our earliest record of this rather uncommon migrant in spring was of an individual noted on May 10, 1928, the latest, May 27, of the same year. Lewis (1927b) has recorded an individual bird which struck the light on May 14, 1925. A fall date of migration is given by Saunders (1930), a specimen having struck the lighthouse between September 24 and 29, 1929. Apparently the species is not a plentiful migrant.

\section{ㅇ May 22, 1928}

Mniotilta varia. BLACK AND WHITE WARBLER.-The earliest spring arrival date according to our records is May 6, 1928, four having been noted. It was a regular and not uncommon migrant until May 18, 1928, on Long Point. A later date, May 19, 1926, is available since seven birds were destroyed at the lighthouse on that date. Mr. R. V. Lindsay saw four between July 4 and 16, 1927, Mr. W. E. Saunders saw one at Turkey Point on June 7 or 8, 1925, and Mr. W. E. Clyde Todd noted a few in the woods about Port Rowan in July, 1907, indicating that this warbler is not a rare summer resident of sections of the mainland. 
$\mathrm{Mr}$. Angus Buchanan has informed the writer that the species bred at Fisher glen in 1926. We did not observe it on Long Point in summer. In September the species is again migrating through the region. The following lighthouse casualties were recorded by Saunders (1930), five on September 7, two on September 9, and two between September 24 and 29,1929 .

\section{우 May 9, 1928}

Vermivora chrysoptera. GOLDEN-WINGed WARBLER.-MCIlwraith (1886) has recorded having heard of this species being noticed at Port Rowan. We have three records of more recent date; one bird was seen by Mr. W. E. Saunders at Turkey Point on May 17, 1925, another was picked up at the lighthouse on Long Point after having been killed there on September 7, 1929, and one was collected at Turkey Point on May 26, 1931, by Mr. D. A. MacLulich who also saw several others there on that day. This warbler has not been seen in summer but it is possible that it occurs as a rare resident during this season.

$$
\sigma^{7} \text { May 26, } 1931 \text { o } \sigma^{7} \text { Sept. 7, } 1929
$$

Vermivora ruficapilla ruficapilla. NAShVILle WARBLER.-Our earliest arrival date is May 6, 1928, when two birds were noted; one of them was collected. The species was particularly common by May 20 of that year. It was seen more infrequently and in decreasing numbers until the end of that month; the last seen, a single individual, was observed on May 30. Mr. W. E. Saunders has noted two in the region as late as June 7 or 8,1925 . This latter record suggests that the species may be found in summer in some sections of the mainland. Nashville warblers are en route southward during September, one having fallen victim to the light on September 7, 1929, and nine between September 24 and 29, 1929 (Saunders, 1930).

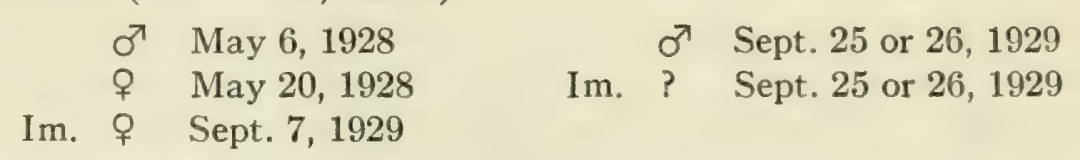

Vermivora celata celata. ORANGE-Crowned WARBLER.-The earliest spring record on Long Point of this migrant which is rare in southern Ontario, is May 14, 1925, a bird having struck the light on that date. Our first record in 1928 was made on May 20, four birds having been seen. Three individuals were noted on May 22 and one, the latest spring record, on May 27. The identification of eight specimens of this species in the field without a specific search for them indicates that numbers pass through this region in spring. No fall records have been secured.

$$
\text { ㅇ May 20, } 1928
$$$$
\text { ? } \quad \text { May 22, } 1928
$$

Vermivora peregrina. Tennessee Warbler.-Apparently not an uncommon spring migrant. Our records include twenty-two which 
struck the light on May 14, 1925 (Lewis, 1927b) and three individuals seen by our party, all on May 22, 1928. It perhaps occurs more plentifully in the fall, thirteen having struck the light on September 7, three on September 9, and twenty-two between September 24 and 29, 1929 (Saunders, 1930).

$$
\begin{aligned}
& \text { 万ั May 22, } 1929 \text { Im. ? Sept. } 7 \text { or } 9,1929 \\
& \text { ? Sept. } 7 \text { or } 9,1929 \text { Im. ? Sept. } 25 \text { or } 26,1929
\end{aligned}
$$

Compsothlypis americana pusilla. NORTHERn PARUla WarBLER.-On July 8, 1927, two singing males were discovered shifting about in the tops of old white pines which grew in clumps among deciduous trees on Squire's ridge. Mr. W. E. Saunders had noted the species on the point on June 1, 1924. Although this warbler is established as a rare summer resident on Long Point, we did not procure information relative to its arrival or migration through the region in spring. Casualties of birds at the lighthouse during September, 1929, however, suggest the time of southward movement of the species. Eight of these birds were destroyed between September 24 and 29 (Saunders, 1930).

$$
\begin{aligned}
& 2 \sigma^{7} \text { 's July } 8,1927 \\
& \sigma^{7} \text { Sept. } 25 \text { or } 26,1929
\end{aligned}
$$

Dendroica tigrina. CAPE MAY WARBLer.-A fairly plentiful spring migrant first observed and collected by us on May 20 in 1928. Our latest spring record was made on May 27 of that year. Earlier spring arrivals are shown by the records of destructions at the Long Point light, two specimens having been killed on May 14, 1925, and one on May 19, 1926. Also a later migration date in spring was made by Mr. W. E. Saunders who saw four of these birds on the point on June 1, 1924. It occurs in the fall in some numbers, the records of casualties being as follows: Fourteen destroyed on September 7, one on September 9, and fifteen between September 24 and 29, 1929 (Saunders, 1930).

In attempting to analyze the age and sex of the fall specimens from Long Point according to the descriptions of the various plumages given in recent literature, it has been found that no agreement is possible with the ages and sexes as determined by dissection. One specimen positively sexed as a female and marked "skull and ovaries mature" conforms in plumage to the description by Forbush (1929) of young females in the first winter. On the other hand, a specimen, which was too disintegrated to sex, is marked "skull clear, soft and thin" while the plumage conforms with Forbush's description of adult males in winter. This bird and others are considered young males (although not listed below as such) and their plumage is more brilliant than that of adult males at any 
season so far as our comparisons with available museum material have shown.
우 May 20, 1928
o' May 22, 1928
우 May 22, 1928
3 Im. P's Sept. 7 or 9, 1929
$\begin{array}{rll} & \text { ㅇ } & \text { Sept. } 25 \text { or } 26,1929 \\ \text { Im. ơ } & \text { Sept. } 25 \text { or } 26,1929 \\ \text { Im. ํ } & \text { Sept. } 25 \text { or } 26,1929 \\ 4 \text { Im. ?'s } & \text { Sept. } 25 \text { or } 26,1929\end{array}$

Dendroica æstiva æstiva. Yellow WARBLER.-Our earliest record of the spring migration of this species in 1928 was made on May 4, although it probably arrives regularly a few days prior to that date. It is a common migrant during early May and a common summer resident, nesting in suitable situations on the point and also on the adjacent mainland. On Ryerson's island, where there were particularly favourable conditions, this warbler used the raspberry canes and thickets of choke cherries in which to nest.

Yellow warblers migrate southward during the early part of September, seven having struck the lighthouse on September 7 and two on September 9, 1929.

$$
\begin{aligned}
& 3 \text { ठ"'s May 12, } 1928 \text { ठ July 4, } 1927 \\
& 2 \text { के's May 27, } 1927 \text { वे July 8, } 1927 \\
& \text { ㅇ June } 8,1927 \text { ? Sept. } 7 \text { or } 9,1929 \\
& \text { o J June 14, } 1927 \text { Im. ? Sept. } 7 \text { or } 9,1929
\end{aligned}
$$

Dendroica cærulescens cærulescens. Black-THROATED BLUE WARBLER.-First observed by our party on May 10, 1928. The latest spring observation was made by Mr. W. E. Saunders on June 1, 1924. This warbler was not particularly plentiful during the spring migration period. In the fall the species occurs in numbers during September and

\begin{tabular}{|c|c|c|c|}
\hline$\sigma^{7}$ & May 9,1928 & q & Sept. 25 or 26,1929 \\
\hline$\sigma^{7}$ & Sept. 7 or 9,1929 & 2 ?'s & Sept. 25 or 26,1929 \\
\hline $\begin{array}{l}\text { m. ? } \\
0^{T}\end{array}$ & $\begin{array}{l}\text { Sept. } 7 \text { or } 9,1929 \\
\text { Sept. } 25 \text { or } 26,1929\end{array}$ & 2 Im. $\sigma^{7}$ & Sept. 25 or 26,1929 \\
\hline
\end{tabular}
it has been found among the victims of the powerful Long Point light. Saunders (1930) has recorded three that were destroyed on September 7 , four on September 9 and thirty-five between September 24 and 29, 1929.

Dendroica coronata. MyrtLE WARBLER.-This warbler, an early migrant, was probably present as a transient at the time of our earliest arrival in the Long Point region, April 30, 1928, but it was a few days before we visited a tract where it was most apt to be found. It was noted regularly, however, from May 3 to 23 ; it is a fairly common species in the region in spring. Our latest spring date is May 27, 1927, one bird having been seen on that date. Curiously enough, only one of these birds has been destroyed by the mariners' light on the end of the point, in spring or fall, so far as our records indicate, although heavy casualties of their allies have occurred during periods in which this species 
is known to be transient in the region. This record is of a female picked up after a destruction which occurred on May 19, 1926.

$$
\begin{array}{llll}
\text { वे } & \text { May 3, } 1928 & \text { वे } & \text { May 6, } 1928 \\
\text { वे } & \text { May 5, } 1928 & &
\end{array}
$$

Dendroica magnolia. Magnolia Warbler.-Our earliest spring record for this species is May 9, 1928. It was not common, however, in that year, until the period between May 17 and 27. Quite a number of casualties of this species have occurred at the lighthouse during May of 1925 and 1926. Our latest spring occurrence was noted on May 30 , 1927. Mr. W. E. Saunders noted it as a migrant in the region on June 1, 1924.

Mr. W. E. Saunders has informed the writer that during July (about the year 1926) he heard and saw a male of this species at Fisher glen. This is an unusual occurrence and it seems unlikely that this warbler is more than a rare, perhaps irregular, summer resident of the region. Thirty-two struck the lighthouse on September 7 , six on September 9 and thirty-six between September 24 and 29, 1929 (Saunders, 1930).

$$
\begin{aligned}
& \sigma^{7} \text { May 19; } 1928 \quad 6 \text { ?'s Sept. } 25 \text { or } 26,1930 \\
& \sigma^{7} \quad \text { May 27, } 1927
\end{aligned}
$$

Dendroica cerulea. Cerulean Warbler.-A singing male was collected on June 27, 1927. It repeatedly changed its singing station in the tops of deciduous trees, and uttered its ascending, somewhat "buzzy" trill at regular intervals. The song was remarkably like one version of the parula warbler's song which was also heard by us in the same vicinity a little later in the season.

The only other record of this species for the Long Point region is from the notes of Mr. W. E. Saunders who remarks that one was shot in the region in 1908 by Mr. G. F. Norval, a local taxidermist.

$$
\sigma^{7} \quad \text { June } 27,1927
$$

Dendroica pensylvanica. Chestnut-SIDED WARBler.-Lewis (1927) has recorded one striking the light on May 14, 1925. It was first recorded by us on May 15, in the spring of 1928, and last noted on May 30, 1927. Mr. W. E. Saunders noted it as late as June 1, 1924 on Long Point. It reached its greatest numbers between May 18 and 27, 1928 , at which time it was a common migrant. Although the species might be expected in summer, no occurrences have been noted. Wm. Pope has figured the nest of this warbler (Locke, 1917), probably one found locally near Port Ryerse. This species is among those subject to destruction by the Long Point lighthouse during both spring and fall seasons. It is on its southern migration during September, casualties at the light giving a range of dates from September 7 to September 29, 1929 (Saunders, 1930).

$$
\text { ठ May 15, } 19282 \text { Im. ?'s Sept. } 25 \text { or 26, } 1929
$$


Dendroica castanea. BAY-BREASTED IWARBLER.-A fairly common spring and fall migrant. The earliest spring record is given by Lewis (1927) twenty-seven birds having been destroyed at the light on that date. We noted a few regularly from May 20 to 27, 1928, our latest record being May 30, 1927, although Mr. W. E. Saunders noted nine on the point on June 1, 1924. In the fall the species reappears in September, seven having been destroyed at the light on September 7 , seven on September 9 and thirty-one between September 24 and 29, 1929 (Saunders, 1930).

$\begin{array}{lll}\text { o }^{7} & \text { May } 20,1928 & 2 \\ \text { क } & \text { Sept. } 25 \text { or } 26,1929 & \text { Sept. } 25 \text { or } 26,1929\end{array}$

Dendroica striata. BLACK-POLL WARBLER.-The earliest record of the arrival of this species in spring has been recorded by Lewis (1927b) eighteen representatives having been picked up at the lighthouse following the destruction on May 14, 1925. Available information indicates that this species is not an uncommon spring migrant. Our records show it to occur through an extended period; we collected a specimen as late as June 2, 1927, and another was positively identified on June 12 of the same year. In the fall, presuming that statistics from lighthouse casualties indicate to a certain extent the numbers of a given migrant, the species is more common than in the spring. Mr. W. E. Saunders (1930) has recorded the exceptionally heavy destruction of this species in the fall of 1929. Thirty-one were killed on September 7, six on September 9 and one hundred and ninety-nine between September 24 and 29 .
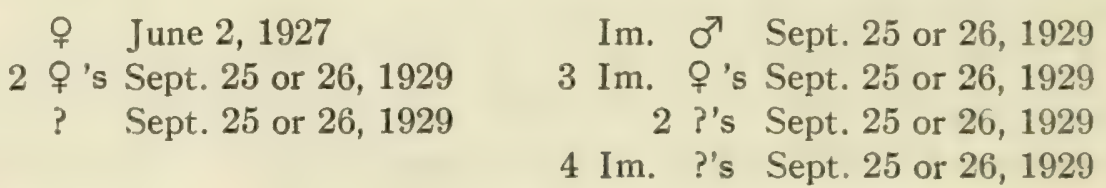

Dendroica fusca. Blackburnian Warbler.-Not noted as a spring migrant in 1928 until after mid-May. Lewis (1927b) records ten which were destroyed by the light on May 14, 1925. It was a fairly common migrant in 1928 between May 18 and 22. Two were noted as late as May 30 in 1927 , and Mr. W. E. Saunders saw five, which may have been migrants, on June 1, 1924. In the fall the species is a common migrant in the region. Saunders (1930) has recorded casualties at the light as follows: Eighty-seven on September 7, twelve on September 9, and four between September 24 and 29, 1929.

This warbler is a rare summer resident of the point. A singing male was collected on June 29, 1927, and a female was observed on July 7 , near the situation where the male had been collected. On July 8 in a wooded area, widely separated from the location where previous records 
had been made, two singing males were observed. The species is probably a rare summer resident on the adjacent mainland.

$$
\begin{aligned}
& \sigma^{\top} \quad \text { May 20, } 1928 \\
& \text { o June 29, } 1927 \\
& 2 \text { Im. ?'s Sept. } 25 \text { or } 26,1929
\end{aligned}
$$

Dendroica virens. Black-throated Green WArbler.-The earliest arrival date of this warbler, according to our records, is May 3, 1928. It was noted during that year rather sparingly until May 18, it being very much in evidence on May 22. Casualties at the light during the spring season are within the dates presented by our frequency charts for 1928. Saunders (1930) records one black-throated green killed at the light on September 7 and seventeen during the period between September 24 and 29, 1929. This species is a common migrant in the region and as a summer resident it is not rare. It was noted on thirteen days during the latter half of June and during July, 1927. The observations were made at a number of distinct localities on the wooded part of the point and as many as five individuals were noted on a single day. The species nests in the white pine to be found on the wooded ridges. One occupied nest which was discovered on Squire's ridge on June 21, 1927, was built on a horizontal limb of a white pine about thirty-five feet from the ground near the top of the tree and situated approximately three feet out from the trunk.

Mr. R. V. Lindsay has noted a "few" black-throated green warblers at Fisher glen in July (1927). The species doubtless occurs regularly in suitable situations along the adjacent mainland.

$$
\begin{array}{llll}
\text { ๙ } & \text { May 3, } 1928 & \text { Im. ? } & \text { Sept. } 25 \text { or 26, } 1929 \\
\text { ठ } & \text { June 23, } 1927 & &
\end{array}
$$

Dendroica vigorsi. Pine WARBLer.-The discovery of this warbler at Long Point in the summer of 1927 added a distinct note of interest to our field work since the summer distribution of the species is so irregular in Ontario as to make the finding of it something of a surprise. It was first heard and seen on July 4 . We were attracted to a brief, rather musical trill coming from the top of a clump of white pines on Courtright ridge. The singer was discovered and immediately collected, and we were surprised to find it to be a young pine warbler in that nondescript plumage in which the genera' aspect of the woolly feathers below are dirty grey while the back is washed with drab brown. The fact that this young of the year was singing is of no less interest than the establishment of a breeding record for the species. Another bird was collected at the same place immediately after the one described above and it also proved to be a juvenile of the pine warbler. A third specimen was later taken on Courtright ridge somewhat removed from the site where the species was first noted but it may have been from the same 
brood. Other plots of pine on Long Point suggest that several sections may be suited to the species.

$$
\text { Juv. } 0^{7} \text { July } 4,1927 \text { Juv. \& July } 23,1927
$$

Juv. ㅇ July 4, 1927

\section{Dendroica palmarum palmarum. Palm Warbler.-This} warbler was not listed by us until May 6 in 1928, although it may have been overlooked previous to that date. It was a fairly common migrant during the remainder of the month reaching the point of greatest number on May 9. Our station on Second island during May, 1928, was a particularly good one in which to observe this species, since it frequented the long line of low willows which fringed the beach of Long Point bay. Our last record was of two individuals seen on May 30, 1928. Judging from casualties at the lighthouse, this species is not on the southward migration through the Long Point region until late September, since none of these birds was picked up until the period between September 24 and 29, 1929.

$$
\begin{array}{cc}
\text { or }^{7} & \text { May 6, } 1928 \\
\text { ㅇ } & \text { May 6, } 1928 \\
\text { वै }^{7} & \text { May 9, } 1928
\end{array}
$$

$0^{7}$ Sept. 25 or 26,1929

ㅇ Sept. 25 or 26,1929

2 ?'s Sept. 25 or 26,1929

2 Im. †'s Sept. 25 or 26,1929

Dendroica discolor. Prairie Warbler.-In the notes of $\mathrm{Mr}$. W. E. Saunders, he records having been told by Mr. A. Preston of Port Dover that the latter had seen a prairie warbler there on May 7, 1914. Although this observation is extralimital to the region with which we are concerned it is included with the following, to indicate the possibility of the occurrence of the species in the general region. On May 31, 1930, Mr. W. E. Saunders saw the prairie warbler on the mainland back of Turkey Point.

Seiurus aurocapillus. Oven-BIRD.-Lewis (1927b) records sixteen of these birds as having struck the Long Point light on May 14, 1925. The earliest record made by our party was of an individual seen on May 15, 1928. It was noted fairly commonly during the period between May 18 and 27 during that year. Our latest record was of a few seen on the latter date. We did not discover the species on the point during the summer of 1927 . The species is known to be a summer resident of suitable woods on the adjacent mainland. Taverner (1914) has also remarked on its absence in the peninsular area of Point Pelee and its presence on the adjacent mainland in that area. A nest was found at Fisher glen in July, 1927, by Mr. R. V. Lindsay and Mr. W. E. Clyde Todd found it breeding near Port Rowan in July, 1917. A tremendous destruction of oven-birds occurred at the lighthouse in September, 1929 
(Saunders, 1930): thirty on September 7, nine on September 9, and one hundred and seven between September 24 and 29.

$$
\begin{aligned}
& \text { ㅇ May } 15,1928 \\
& 2 \text { 7's Sept. } 25 \text { or } 26,1929
\end{aligned}
$$

Seiurus noveboracensis noveboracensis. WATER-THRUSH.Our earliest record for the water-thrush was made on May 6, 1930, three individuals being seen, one of which was collected. Lewis (1927b) records two which had struck the light on May 14, 1925, and reports from the lighthouse keeper mention two destroyed on May 19, 1926, which is the latest date of the spring migration of the species. From our observation it is not a plentiful migrant in spring. No summer records are known to the writer, but it would seem that it should be found in favourable dark swampy woods on the adjacent mainland. Saunders (1930) records it as a September migrant, thirty-six striking the light on September 7, five on September 9, and five between September 24 and 29, 1929.

An examination of the five skins of this species from Long Point, one in spring and four in the fall, does not disclose specimens which are not referable to noveboracensis, although it might here be admitted that the writer has not been able to get a very clear conception of these two forms from available material, or from the literature.

$$
\begin{array}{llr}
\text { ○ } & \text { May } 6,1928 & 2 \text { ㅇ 's Sept. } 25 \text { or } 26,1929 \\
\text { ㅇ } & \text { Sept. } 7 \text { or } 9,1929 & \text { ? Sept. } 25 \text { or } 26,1929
\end{array}
$$

Seiurus motacilla. Louisiana Water-Thrush.-Mr. W. E. Saunders observed a Louisiana water-thrush at Turkey Point on May 17, 1925. We have no other evidence suggesting that the species is established in the region.

Oporornis agilis. Connecticut Warbler.-A specimen of Connecticut warbler was listed by Lewis (1927b) among the bird casualties at the Long Point lighthouse on May 14, 1925. This constitutes the earliest record in spring for this species. Mr. W. E. Saunders noted one on the point on June 1, 1924, and we collected a specimen on June 4, 1927. This warbler can only be considered as a scarce, late spring migrant in the region, although in the fall it appears in numbers as attested by specimens picked up at the lighthouse. Mr. W. E. Saunders (1930) has recorded the fatality of eight on September 7, six on September 9, and thirty-five between September 24 and 29, 1929.
우 June 4, 1927
$\sigma^{7}$ 's Sept. 7 or 9,1929
우 Sept. 7 or 9,1929
2 Im. 우's Sept. 7 or 9, 1929
$\sigma^{7} \quad$ Sept. 25 or 26,1929
3 ㅇ 's Sept. 25 or 26, 1929
? Sept. 25 or 26,1929
3 ?'s Sept. 7 or 9, 1929
Im. $\sigma^{\top}$ Sept. 25 or 26,1929
2 Im. ?'s Sept. 25 or 26,1929 
Oporornis philadelphia. Mourning Warbler.-Not uncommon as a spring migrant; twenty-three struck the lighthouse on May 14, 1925 (Lewis, 1927b), one picked up by the lighthouse keeper on May 19, 1926, and one collected by us on June 4,1927 . In the fall the species passes through the region in considerable numbers during September. The records of casualties at the light as recorded by Saunders (1930) are as follows: Twenty on September 7, five on September 9, and twelve between September 24 and 29, 1929.

$\begin{array}{llll}\text { o } & \text { May } 20,1928 & \text { Im. ? } & \text { Sept. } 7 \text { or } 9,1929 \\ \text { क } & \text { Sept. } 7 \text { or } 9,1929 & & \end{array}$

Geothlypis trichas trichas. Maryland Yellow-THROAT.A common spring and fall migrant and also a plentiful summer inhabitant of suitable situations both on the point and on the adjacent mainland. The earliest arrival date for the species according to available records is May 3, two having been noted by us on that date in 1928. It was at its greatest numbers from May 17 to 22 during that spring.

A nest found in a small wet hollow in the open wood of Ryerson's island was concealed in a tufted clump of coarse, marsh grass. It contained one fresh egg on June 8, 1927. Although the nest and egg were not disturbed they were found to be abandoned a few days later.

A very heavy destruction of this warbler took place during the fall of 1929 (Saunders, 1930). One hundred and eleven were killed on September 7, twenty-nine on September 9 and one hundred and fourteen between September 24 and 29. This is the heaviest toll of any species within any one month so far as our records indicate.

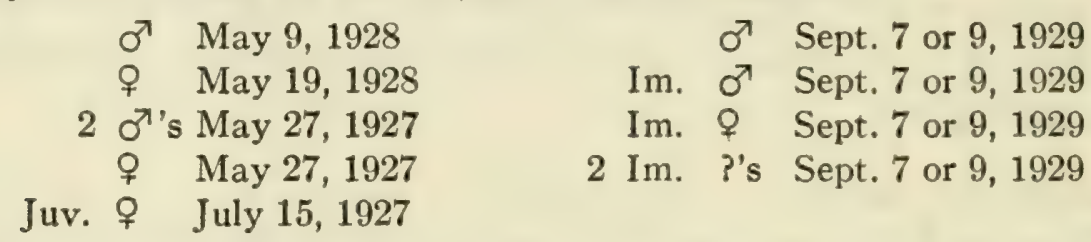

Icteria virens virens. Yellow-BREAsted Chat.--On June 14, 1927 , a chat was collected from a dense tangle of berry canes, climbing vines and other plants at the end of a small clearing in the woods of Ryerson's island. The surroundings were very suited to the species and the lateness of the date indicates that the bird was established as a summer resident. Although we have secured no other records for the region covered in the present paper, the information as to the distribution of this species on the north shore of Lake Erie suggests that it may be found as a rare summer resident of suitable situations on the mainland adjacent to Long Point.

\& June 14,1927

Wilsonia citrina. Hooded WARBLER.-McIlwraith (1886) states that Mr. G. F. Norval reported finding this warbler occasionally at 
Port Rowan. In the notes of Mr. W. E. Saunders he records having been told by Mr. Norval that the latter had shot one on the point about 1888. Although no more recent records of the occurrence of the species in the Long Point region have been found, it may still be expected as a rare visitor, perhaps a summer resident.

Wilsonia pusilla pusilla. WiLson's WARBLER.-Lewis' record (1927b) of casualties at the lighthouse lists fifteen Wilson"s warblers destroyed by the Long Point light on May 14, 1925, the date being the earliest for the spring season. We saw one on May 22, 1928, and one on May 27 of the same year. The latest spring migration date is of four birds noted on Long Point by Mr. W. E. Saunders on June 1, 1924. It is apparently not a common warbler in spring, and our fall records which only apply to September suggest that it is not numerous in that month. Saunders (1930) lists only eight birds destroyed between September 7 and 29, 1929.

$$
\begin{array}{llll}
\text { ơ } & \text { May 22, } 1928 & \text { Im. ? } & \text { Sept. } 7 \text { or } 9,1929 \\
\text { ㅇ } & \text { Sept. } 7 \text { or } 9,1929 & &
\end{array}
$$

Wilsonia canadensis. CANADA WARBLER.-The earliest arrival of this species is recorded by Lewis (1927b) in his paper on lighthouse destruction of birds. This was on May 14, 1925, thirty-one representatives of the species having been found after a destruction on that date. Our earliest record in 1928 was made on May 18, two birds having been noted, and our latest record of this species as a migrant in spring was two birds seen on May 30, 1927. Mr. W. E. Saunders saw it on June 1, 1924, on Long Point, this observation doubtless being of transient individuals, since we did not find the species a summer resident of the point. Mr. R. V. Lindsay noted four during the first two weeks of July, 1927, at Fisher glen. The species is probably an uncommon summer resident elsewhere along the mainland adjacent to Long Point. Saunders (1930) gives migration dates for this species in the fall in recording casualties as follows: eleven on September 7, seven on September 9, and three between September 24 and 29, 1929.

$$
\begin{array}{llll}
\sigma^{7} & \text { May } 22,1928 & \text { Im. } \sigma^{7} & \text { Sept. } 25 \text { or } 26,1929 \\
\text { ? } & \text { Sept. } 7 \text { or } 9,1929 & &
\end{array}
$$

Setophaga ruticilla. REDSTART.-The earliest spring arrival date was obtained by our party on May 6, 1928, but the species did not reach the area in numbers until mid-May. It continued to be recorded as a migrant until the third week of May of that year. It was a common nesting species on the point in 1927 - one of the most common woodland birds noted there. Available information suggests that it is more common on the peninsula than on the adjacent mainland as a summer resident. 
We found it nesting on Ryerson's island on June 8, 1927, and later in the summer incidental observation in wooded areas such as Courtright and Squire's ridges revealed several occupied nests. September is the period of southern migration of the redstart. The earliest date is marked by an individual specimen forwarded to the Museum by $\mathrm{Mr}$. Lorne Brown, which had been killed at the lighthouse on September 2, 1930. Saunders (1930) records twenty-three individuals as having been picked up following a destruction by the light on September 7, three on September 9, and forty between September 24 and 29, 1929.

Immature males (first breeding plumage) collected during the summer of 1927 , appeared to be breeding birds. The testes were greatly enlarged and the birds were in full song.

\begin{tabular}{|c|c|c|}
\hline & & May 19,1928 \\
\hline $\operatorname{Im}$ & & May 22,1928 \\
\hline $\mathrm{m}$ & రా & June 7,1927 \\
\hline & $\sigma^{7}$ & June 21,1927 \\
\hline & $\sigma^{7}$ & June 23,1927 \\
\hline
\end{tabular}

$$
\begin{aligned}
& \text { Im. ठ๐ June 29, } 1927 \\
& \text { Im. ㅇ Sept. 2, } 1930 \\
& 2 \sigma^{7} \text { 's Sept. } 25 \text { or 26, } 1929 \\
& 2 \text { ?'s Sept. } 25 \text { or } 26,1929 \\
& 2 \mathrm{Im} \text {. ?'s Sept. } 25 \text { or } 26,1929
\end{aligned}
$$

Anthus rubescens. Pipit.-On the morning of our arrival at Port Rowan on April 30, 1928, we paid a brief visit to the area bordering the western edge of inner Long Point bay and the base of the peninsula. Along the new road which had been constructed through the marsh of this section, twenty pipits were observed. The species was again noted on Second island on May 17 of that year. These were the only records obtained although it is probably a fairly common and regular transient in spring and perhaps the same is true for the fall, but we have no records for that season. The probabilities are based on occurrences in the general region.

ㅇ. May 17, 1928

Dumetella carolinensis. CATBIRD.-Our earliest spring record is of five individuals observed on May 6, 1928. It was a fairly common transient from that date until the third week of May. It has not been possible to set an exact date when the last transient of this species was noted since circumstances of observations confuse individuals which may have been established for the summer with those which may have been on the move, but May 18 was the latest date on which considerably greater numbers were recorded for Ryerson's island than would represent its summer population. Four casualties of this species at the Long Point lighthouse have been reported, all on May 19, 1926. This gives the latest date for the spring migration.

Very few catbirds remain on Long Point to nest since the barren conditions in regard to undergrowth restrict suitable habitat for the species. We found a nest with three young on June 14, 1927, on Ryer- 
son's island. The species is a more plentiful summer resident on the adjacent mainland.

$\sigma^{7}$ June 8,1927

Toxostoma rufum. Brown Thrasher.-This species was found only as a scarce migrant on Long Point, five being the greatest number noted on any one day during the first half of May, 1928. The last one was recorded on May 20. Available records do not list the brown thrasher as a summer resident in the region. Although it is probable that a few may inhabit suitable sections of the mainland, it is rather surprising that it is not found to be a fairly numerous species generally. † May 3, 1928

Thryothorus ludovicianus ludovicianus. CARolina Wren.On June 12,1927 , our party made a preliminary trip to the wooded ridge south of our Second island camp to ascertain the nature of that territory for further collecting. Immediately after landing a Carolina wren was heard in a vine-draped tree near the shore. The specimen was discovered and shot, but, much to the disappointment of the four men who gathered round the spot, the badly injured bird escaped into the tangle of vines at the base of the tree and disappeared. During a brief instant the bird was within two feet of the writer's face. All efforts to uncover the specimen failed, and through some curious circumstance we did not again discover this species on the point until the day of our departure on July 26. To make the two observations more remarkable, the second was heard in the same vine-draped tree as the first, this cover being within fifty feet of our Courtright ridge camp, where we had remained for a period of over a month.

Troglodytes ædon ædon. House Wren.-First noted by us on May 7, 1928, although this date would appear to be late for the usual arrival of the species in spring. It was noted as a migrant until the third week of May. The latest record is of a bird killed at the lighthouse on May 19, 1926. No information relative to the fall migration of this species is available. It is a common summer resident of Long Point and vicinity, nesting in clearings in the woods and about habitations.

$$
\begin{aligned}
& 0^{7} \text { June } 8,1927 \\
& \text { Juv. O' June 29, } 1927 \\
& \text { Juv. \& June 29, } 1927 \\
& \begin{array}{rr}
\stackrel{9}{\text { June }} 30,1927 \\
\text { Juv. }
\end{array}
\end{aligned}
$$

Nannus hiemalis hiemalis. WINTER WREN.-This early migrant was present at the time of our earliest arrival in the region (April 30,1928 ) but it was still moving in limited numbers during the first few days of our stay. Three were noted on May 6, this being the latest spring record. No evidence that the species is a summer resident of the region has been secured. 
Cistothorus stellaris. Short-Billed Marsi Wren.-On June 12,1927 , short-billed marsh wrens were discovered in the somewhat wet, grassy, flat land between Squire's and Courtright ridges. Four individuals were noted on this occasion. A search of this area later in the summer disclosed that an extensive territory was occupied by this species and a few were noted regularly; as many as ten individuals were seen on a single day. Mr. W. E. Clyde Todd had discovered a marsh wren's nest containing four white eggs which were collected. He considered these to be of the short-billed species although he did not see the bird. We collected a juvenile bird on July 16, which leaves no doubt that the species breeds in the region.

$\begin{array}{llr}\sigma^{7} & \text { June 24, 1927 } & \text { Juv. ? July } 16,1927 \\ \sigma^{7} & \text { July 14, 1927 } & 5 \text { वे's July 23, } 1927 \\ \sigma^{7} & \text { July 16, 1927 } & \end{array}$

Telmatodytes palustris palustris. LONG-BILLEd MARSH Wren. -First observed in the spring of 1928 , on May 12, but not noted commonly until May 25 and thereafter. It was a common inhabitant of certain favoured sections of the marsh during the summer of 1927 . Many nests were found during the summer of that year. The earliest date on which a set of five eggs was found was June 4. It may have been a completed clutch. The species is also found in the marshes on the mainland such as those of Turkey Point.

$$
\begin{array}{ll}
\sigma^{7} & \text { May 31, } 1927 \\
\sigma^{7} & \text { June 4, 1927 } \\
\sigma^{7} & \text { June 14, } 1927 \\
\sigma^{7} & \text { July 7, 1927 }
\end{array}
$$

$$
\begin{aligned}
& 4 \sigma^{77} \text { 's July } 11,1927 \\
& \sigma^{7} \text { July } 18,1927 \\
& \text { 万' July 23, } 1927
\end{aligned}
$$

Certhia familiaris americana. BRown CREEPER. - The brown creeper was present as a migrant at the time of our arrival in the region on April 30, 1928. On May 3 it was present in great numbers, this being the peak of their spring movement so far as our observations were concerned. They were transient in the region until May 12, this date marking our latest spring record. No creepers were seen on the point during the summer of 1927 , and we have no summer records for the mainland.

$$
\text { o } \text { May 2, } 1928
$$

Sitta carolinensis carolinensis. WhITE-BREAsted NutHATCH.A few migrating white-breasted nuthatches were observed during the early part of May in 1928, five being the greatest number noted on one day. May 10 appeared to mark the close of their movement although one was seen on May 20; it may have been a transient bird. Quite a number of these nuthatches remain on Long Point to breed, and they are summer residents of the adjacent mai, $i_{\ldots .1}$ also. We noted a few rather irregularly when encamped in a wooded section of the point, 
the numbers observed increasing somewhat after the first of July, doubtless due to the young birds being on the wing.

The white-breasted nuthatch was included by Taverner (1914) in a list of species which reside on the mainland at the base of Point Pelee but not on the peninsula. Although a similar distributional status for several of the same species recorded by Taverner has been noted by us in the Long Point region, the nuthatch is exceptional since it occurs both on the mainland and on the point.

$$
\begin{aligned}
& \text { ㅇ May 2, } 1928 \\
& \text { o June 4, } 1927 \\
& \begin{aligned}
\stackrel{\text { J }}{\text { June } 23,1927} \\
\text { Juv. ? June 23, } 1927
\end{aligned}
\end{aligned}
$$

Sitta canadensis. Red-BReasted Nuthatch.-Our only record of this species is of the five seen on Long Point by Mr. W. E. Saunders on June 1,1924 . It is probably a regular transient in the region.

Penthestes atricapillus atricapillus. ChickadeE.-It was rather difficult to distinguish transient or wandering chickadees from resident individuals, but our observations show that these birds were moving about in early May of 1928. May 6 is the latest date for known transients. The species is not an uncommon nesting one on the peninsula. We saw from one to six almost daily, more individuals having been seen after the first of July when the young were in evidence. It is a fairly common inhabitant of the adjacent mainland.

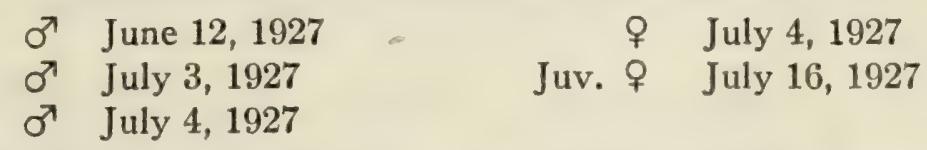

Regulus satrapa satrapa. Golden-CRowned Kinglet.-A few rear-guard spring migrants were noted in early May, 1928, the last, a single individual, on May 6. We have no information relative to this species in fall or winter, but it probably occurs in numbers during those seasons.

$$
\text { 우 May 6, } 1928
$$

Regulus calendula calendula. Ruby-CROwned KingLet.-Like the preceding, this kinglet was still present as a migrant on Long Point during early May of 1928 , but this species remained much later and was seen in greater numbers. It was a common bird on May 6, and we continued to note it until May 18. It also probably occurs in the region in some numbers in the fall.

$$
\text { 우 May 3, } 1928
$$

Hylocichla mustelina. Wood THRUsh.-A specimen of wood thrush which struck the Long Point light on September 26 constitutes our only record of the species in the region. The specimen is preserved in the collection of Mr. W. E. Saunders. 
Hylocichla fuscescens fuscescens. VEery.-The arrival date of this thrush in 1928 was May 6, four individuals having been seen. It was a fairly common bird by May 18, gradually diminishing in numbers, the last having been seen on the $27 \mathrm{th}$. One had previously been seen on that date in 1927. It is rather interesting that the veery was not found on Long Point in summer since it is not an uncommon summer resident of the adjacent mainland. The absence of this species on the peninsula of Point Pelee and its presence in the surrounding country at the base has been noted by Taverner (1914). Habitat conditions partially account for the absence of the veery on Long Point. Six specimens which struck Long Point light on September 7 and one destroyed there on September 9 have been recorded by Saunders (1930).

$$
\text { ơ May 6, } 1928 \quad \text { Im. 우 Sept. } 7 \text { or } 9,1929
$$

Hylocichla aliciæ aliciæ. Gray-CHEEKED Thrush.--Noted rarely by us in May of 1927 and 1928. The records are as follows: One on May 4, one on May 12, and one on May 18, 1928; and one on May 27, and one on June 4, 1927. Lighthouse casualties during the period indicated by the above dates, together with our observations, show that this species is present in fair numbers in spring, and that its movement through the region is protracted. In the fall heavy casualties occur (Saunders, 1930) especially in late September. One hundred and fifty were picked up after destructions at the light between September 24 and $29,1929$.

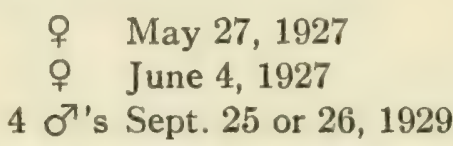

2 우's Sept. 25 or 26,1929

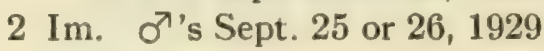

Hylocichla ustulata swainsoni. Olive-Backed Thrush.The earliest date of arrival obtained by us was May 4, 1928, two birds having been seen. The species was common on May 6, 18 and 27, being noted in less numbers regularly between those dates. Our latest date was May 28, 1927, one bird having been noted. Olive-backed thrushes are common migrants again in the fall. Saunders (1930) has recorded eighteen as having been destroyed at the lighthouse on September 7, ten on September 9, and one hundred and forty between September 24 and 29, 1929.

$$
\begin{array}{ll}
\sigma^{7} & \text { May 5, } 1928 \\
\sigma^{7} & \text { May 27, } 1927
\end{array}
$$

? Sept. 7 or 9,1929

? Sept. 25 or 26,1929

Hylocichla guttata pallasi. Hermit Thrush.-Six hermit thrushes struck the lighthouse on April 17 or 18, and two on April 20 or 21,1930 . This thrush was present at the time of our arrival in the Long Point region on April 30, 1928. It was fairly common for the first few days, the last being seen on May 6. Our only record for the 
fall is that of Saunders (1930), an individual being listed among the casualties at the light which occurred between September 24 and 29, 1929.

$$
\text { o May 3, } 1928
$$

Planesticus migratorius migratorius. RoBIN.-Six robins were killed at the Long Point light on April 17 or 18, 1930. Although the species is an early migrant there was some evidence of a northward movement during the first few days of May in 1928. A few birds were noted daily on Second island where only one pair was known to be established during the previous summer. Lewis (1927b) has recorded a robin which struck the lighthouse on May 14, 1925. The bird was undoubtedly a migrant. Robins were not plentiful on Long Point in summer. A pair was established here and there, particularly about the various camps which have been built there. The species is not to be met with regularly or in numbers in the woods away from camps. They are, of course, common on the mainland.

Mr. Angus Buchanan has related to the writer that he had made a motor trip along the north shore of Long Point bay during the fall of 1928 . He stated that in travelling from five miles east of Port Dover to Turkey Point flocks of robins were almost constantly in evidence. These birds were feeding and travelling westward along the shore, giving a rather clear impression of the birds skirting the bay rather than flying across it.

$$
\text { Juv. O' June 12, } 1927
$$

Sialia sialis sialis. BLUEBIRD.--Noted fairly regularly but not commonly as a migrant during May, 1928, the last transient bird having been noted on May 19. It is a rather scarce summer resident of the point but more common on the mainland. We secured no information relative to the status of the species as a migrant in the fail.

ㅇ June 25,1927

\section{HypotheTICAL List}

Colymbus holbœlli. Holbcel's Grebe.-Local sportsmen appeared to know this species and described it to us as a fairly regular but rather an uncommon bird found in early spring and late fall. Among the paintings by Wm. Pope (Locke, 1917) which are housed in the Toronto reference library there is one of an adult of this species in winter plumage, which is dated October 20, 1859. The representation was probably from a bird taken locally, but our evidence as to the occurrence of this grebe is such as to make its inclusion more satisfactory with hypothetical cases.

Gavia pacifica. PACIFIC Loon.-Mr. L. J. Boughner reported the black-throated loon as being observed at Long Point by him in June, 
1898, and the name, Urinator arcticus, was included under Boughner's bird notes edited by W. T. Macoun (1898). If the bird observed was of the black-throated type, it should be considered as the Pacific loon.

Pelecanus erythrorhynchus. White Pelican.-A member of the life-saving crew stationed near the end of Long Point informed Mr. W. E. Saunders on June 7, 1925, that a white pelican had been seen there in April, 1923. Although the information is probably correct, the record is perhaps best placed under the hypothetical list.

Branta bernicla glaucogastra. BRANT.-Apparently no specimens of this species are extant in collections but the brant is included in the hypothetical list on the authority of local sportsmen who have stated that they have seen and shot it in the Long Point marshes in the fall. The brant can only be suspected as being a rare and irregular migrant of the district.

Mycteria americana. Wood IBIs.-Fleming (1913) has recorded the taking of a specimen of this species near Simcoe, Norfolk county, in November, 1892. The excellent drawing of the dead bird on which this record was based is now on file in the Museum. The species is included in the hypothetical list of birds of Long Point because the specimen recorded was taken but a short distance outside of the area considered as the "vicinity" of Long Point, and to record the present location of the original basis for the record.

Grus americana. Whooping Crane.-Macoun (1898) reports this species in a list of birds submitted to him by L. J. Boughner as having been seen on "Long Island, Lake Erie" in 1898. The crane was supposed to have been seen on June 29 , but the record is merely the casual inclusion of the name without comments. Since the species was of such rare occurrence in Ontario, strong evidence would appear necessary to give credit to the report, although the list as a whole appears to be well founded.

Phalaropes fulicarius. Red Phalarope.-Townson (1928) writes that "two phalaropes passed the decoys and settled on the water about two hundred yards to windward" on October 24, 1927. Two days later he saw another phalarope pass the decoys, but it "refused to mingle with the imitation ducks, as they sometimes do." Mr. Townson has informed the writer that he was not certain of the species but suspected from the size of these birds that they were Wilson's phalarope (Steganopus tricolor). The dates and circumstances of this observation and the large size of the birds seen suggest that they were more probably $P$. fulicarius. Wm. Pope (Locke, 1917) figures this species and dates the work, October 15, 1868.

Bartramia longicauda. UPLAND Plover.-Nash (1908) states that he has found it breeding in Norfolk county. The species may occur 
within the area considered in the present report, but definite information has not been obtained.

Columba livia. Domestic Pigeon.-Although it may appear that the inclusion of the domestic pigeon is out of place in this list, the writer here includes it with hypothetical cases since there is a suspicion that the species may have the status of a wild bird in the area. On July 4, 1927, a pigeon of the ordinary blue phase was seen at Breakwater on the south beach. This location is approximately ten miles across the marsh from any settlement or habitation. Again on July 8 the same or a similar bird was seen at Breakwater. It was perched in the branches of a dead tree and upon being flushed it again returned to this situation.

Cathartes aura septentrionalis. TURKEY VUltuRE.-In a letter to Professor J. R. Dymond, under date of December 13, 1930, Mr. Munroe Landon, an observer at Simcoe, Norfolk county, states that a pair of turkey buzzards "have been in Norfolk this summer". This record brings the casual occurrence of the species within the realm of possibility for the more exact locality, Long Point.

Buteo lineatus lineatus. RED-SHOULDERED HAwK.--Although this species is probably of regular occurrence in the Long Point region and indeed one would expect that it was a summer resident of wooded sections of the mainland, we have secured no positive evidence of its occurrence at any season. William Pope painted a picture of this hawk (Locke, 1917) and it is probable that the illustration was made from a specimen secured near Port Ryerse.

Buteo platypterus. BROAD-wINGED HAwK.-It would appear that this hawk should occur during migrations in the Long Point region but our only evidence is a painting in the Pope collection (Locke, 1917) which was probably made at Port Ryerse from a locally taken specimen.

Falco columbarius columbarius. Pigeon Hawk.-The only record covering this species was obtained from the notes of Mr. W. E. Saunders, who states that Mr. Lorne Brown, the present lighthouse keeper, saw one strike down a dove near the light. Although the species should occur regularly, particularly as a fall migrant, it is perhaps best to consider it as hypothetical until substantiation is obtained. The observation might well describe the behaviour of a species other than the pigeon hawk, one or two of which would be similar in general appearance.

Strix varia varia. BARRED OWL.-There is apparently no reason why the barred owl should not occur on Long Point or in its immediate vicinity but no positive evidence that it does so has been secured. $\mathrm{Mr}$. W. E. Saunders heard it on June 5, 1926, at Walsingham swamp, northwest of Port Rowan. This record is, however, somewhat removed from the area being considered in this paper. An illustration of the species 
among the Pope pictures (Locke, 1917) was probably based on a specimen found in the neighbourhood of Port Ryerse.

Centurus carolinus. RED-BELlied WoOdPECKER.-The only indication that this species occurs, or has occurred in the region, is the inclusion of it among the bird illustrations made by Wm. Pope (Locke, 1917) while he was resident at Port Ryerse.

Hesperiphona vespertina. EventNG GROSBEAK.-A painting of this bird in the collection of illustrations by Wm. Pope (Locke, 1917) was probably taken from a specimen secured in the neighbourhood of Port Ryerse, but the evidence is too uncertain to be presented other than under hypothetical cases. The picture here referred to is of a male and is dated February, 1860.

Pinicola enucleator leucura. Pine Grosbeak-Three illustrations of this grosbeak are among the Pope pictures (Locke, 1917) now in the public reference library of Toronto. Pope probably based his illustrations on birds collected near Port Ryerse. One painting of a female is dated November, 1842, and another March 2, 1865.

Loxia leucoptera. White-Winged Crossbill.-A male specimen, probably taken locally, is among the bird illustrations executed by Wm. Pope during his residence at Port Ryerse, Ontario (Locke, 1917). The picture is dated November, 1875.

Plectrophenax nivalis nivalis. SnOw Bunting.-A picture of this species, dated February 9, 1860, is among the Pope paintings (Locke, 1917). The picture was probably made from a specimen taken locally near Port Ryerse.

Chondestes grammacus grammacus. Lark Sparrow.-Dale (1931) has recorded the finding of a nest containing four eggs, by J. F. Calvert, about half a mile south of Walsingham village on May 24, 1930. This locality is sufficiently close to the area here considered to render possible the occurrence of the species within the area.

Bombycilla garrula. Bohemian Waxwing.--Cross (1890) has recorded the taking of three specimens of this waxwing at Port Dover, Norfolk county, on February 20, 1890, one of which was forwarded to him. The occurrence of the species at Port Dover is somewhat outside the area considered in this paper, but it indicates the possibility of occurrence in the region during any one of the sporadic invasions of the species into southern Ontario.

Lanius borealis. NORTHERn SHRIKE.-Probably occurs more or less regularly in winter, but our only evidence of occurrence is based on an illustration by Wm. Pope (Locke, 1917) made October 23, 1865, probably from a bird taken in the region. 


\section{LITERATURE CITED}

Baillie, J. L., Jr. 1928. Some late records of the snowy owl for southern Ontario, Auk, 45:99-100.

Bent, A. C. 1927a. Life histories of North American marsh birds. U.S. Nat. Mus. Bull., 134.

Bent, A. C. 1927b. Life histories of North American shore birds. U.S. Nat. Mus. Bull., 142.

Bigelow, Henry B. 1907. On hybrids between the mallard (Anas boschas) and certain other ducks. Auk, 24:382-388.

Bishop, Louis B. 1921. Description of a new loon, Auk, 38:364-370.

Cottle, T. 1859. A list of birds found in Upper Canada. Can. Nat. and Geol., 4:232.

Cross, Wm. 1890. Ampelis garrulus in Ontario. Trans. Can. Inst., $1: 53$.

Dale, E. M. S. 1931. Nesting of the lark sparrow. Can. Field-Nat., $45: 21$.

Durand, Chas. 1897. Reminiscences of Charles Durand of Toronto, Barrister. Toronto, p. 45.

Fleming, J. H., and Hoyes Lloyd. 1920. Ontario bird notes. Auk, $37: 432$.

Fleming, J. H. 1906. Birds of Toronto, Ontario. Auk, 23:446.

Fleming, J. H. 1913. Ontario bird notes. Auk, 30:226.

Forbush, Edward Howe. 1929. Birds of Massachusetts and other

New England states. Dept. of Agri., Boston. Vol. III, p. 228.

Fuertes, L. A. 1916. Notes on hybrid ducks from Long Point, Ontario. Auk, $33: 75$.

Giles, J. Bevans. 1880. Long Point. The happy hunting ground. Forest and Stream and Rod and Gun, 15:26.

Godley, John Robert. 1844. Letters from America, London, Eng., vol. 1, p. 246.

Halkett, Andrew. 1898. An Ottawa naturalist's journey westward. Ottawa Nat., 12:83.

[Hallock, Chas.]. 1876. Forest and stream, 7:150.

Harris, Edward. 1905. The quail. Wm Briggs, pub. Toronto.

Hobson, W. D. 1906. A knot on Lake Erie. Ont. Nat. Sc. Bull., No. 2 , p. 42.

Howe, Reginald Heber, Jr. 1902. Occurrence of the barn owl in Canada. Auk, 19:79.

Howison, John. 1821. Sketches of Upper Canada. London, Eng., p. 160 .

Lewis, H. F. 1927a. A distributional and economic study of the European starling in Ontario. Univ. Toronto Stud., Biol. Series, No. 30 , p. 9 . 
Lewis, H. F. 1927b. Destruction of birds by lighthouses in the provinces of Ontario and Quebec. Can. Field-Nat., 41: 55-58; 75-77.

Lincoln, Frederick C. 1922. Trapping ducks for banding purposes. Auk, 39:322-334.

Locke, George H. 1917. Water colour drawings by William Pope. Public Library, Toronto.

McIlwraith, T. 1866. List of birds observed near Hamilton, Canada West. Essex Inst. Communications, 5:80-91.

McIlwraith, T. 1886. The birds of Ontario. Hamilton, 1st edition. McIlwraith, T. 1894. The birds of Ontario. Toronto. 2nd edition. Macoun, W. T. [Editor] 1898. Bird notes for June. Ottawa Nat., $12: 88$.

Macoun, John. 1900-1903. Catalogue of Canadian birds (Parts I and 2). Ottawa.

Macoun, J., ad J. M. Macoun, 1909. Catalogue of Canadian birds. Ottawa.

Nash, C. W. 1908. Vertebrates of Ontario. Dept. of Education, Toronto.

National Parks of Canada. 1928. Official Canadian record of bird banding returns. Can. Field-Nat., 42:110.

Need, Thomas. 1838. Six years in the bush. London, Eng., pp. 29-33.

Phillips, John C. 1922. A natural history of the ducks. Boston and New York.

Saunders, W. E. 1926. Hudsonian godwit in Ontario. Can. FieldNat., 40:113.

Saunders, W. E. 1930. The destruction of birds at Long Point lighthouse, Ontario, on 4 nights in 1929. Auk, 47:507-511.

Small, H. B. 1866. The Canadian handbook and tourists' guide. Montreal, p. 161.

Smith, Wm. H. 1851. Canada: Past, present and future. Toronto, vol. 1, p. 126.

Snyder, L. L. 1928a. Double ovaries in Circus hudsonius. Auk, 45:98-99.

Snyder, L. L. 1928b. The western sandpiper, Ereunetes mauri, in Ontario. Auk, 45:207.

Snyder, L. L. 1929. Second Canadian record of Bachman's sparrow. Auk, 46:119.

Snyder, L. L. 1930. Sexual differentiation in the plumage of the blackbellied plover. Auk, 47:79-80.

Taverner, P. A., and B. H. Swales. 1907-1908. The birds of Point Pelee. Wilson Bull., 14:37-54 and 15:82-99. 
Taverner, P. A., and B. H. Swales. 1911. Notes on the migration of the saw-whet owl. Auk, 28:33.

Taverner, P. A. 1914. Geological survey museum work on Point Pelee, Ont. Ottawa Nat., 28:97-105.

Townson, John. 1928. Some observations of bird life. Rod and Gun and Can. Silver Fox News. 30:401-402.

(Editorial) 1883. Forest and Stream, 21:15. 



\title{
A FAUNAL INVESTIGATION OF LONG POINT AND VICINITY, NORFOLK COUNTY, ONTARIO
}

\section{THE AMPHIBIANS AND REPTILES OF LONG POINT}

\author{
By E. B. S. LogIER
}

In 1927 the writer spent eighteen days between May 25 and June 13 at Long Point as a member of the Museum party. The other members of the party remained at the point that year until the end of July and visited it again in May, 1928, remaining there for a month. In May, 1929, Mr. W. J. LeRay spent one day, the 14th, at Long Point in company with Dr. J. A. Campbell. In July, 1929, the writer in company with Mr. LeRay, spent two more days, the 12 th and 13 th, at this interesting place. It was during these visits that the specimens and data upon which the present paper is based were gathered and the writer wishes here to acknowledge the kind co-operation of his fellow members of the Museum party and the above mentioned gentlemen. All of the visits to Long Point were made possible through the kindness of the late Mr. H. B. Johnson.

The herpetological fauna of Long Point exhibits some interesting peculiarities as compared with that of other localities in southern Ontario. One is impressed by the apparent absence of Ambystoma and Plethodon among the salamanders, of all Hylidae, of Rana clamitans and Rana sylvatica, and by the scarcity of Bufo americanus. Long Point offers a variety of physiographic conditions which appear to comply with the requirements of these species as indicated by their habitat preferences in localities where they are common. There can be little doubt that the great abundance of garter snakes is a potent factor in suppressing amphibians. On the other hand, that certain species as the leopard frog and Fowler's toad should escape destruction while other equally or more powerful species like the green frog and the American toad should be preyed upon to, or nearly to the point of extermination, seems unlikely.

Jefferson's salamander (Ambystoma jeffersonianum), the spotted salamander (Ambystoma maculatum), the red-backed salamander (Plethodon cinereus), the American toad (Bufo americanus), the spring peeper (Hyla crucifer), the tree-toad (Hyla versicolor), the wood frog (Rana sylvatica) and the green frog (Rana clamitans) are all common and successful species in southern Ontario and their ranges include the north 
shore of Lake Erie. Yet for some reason they are apparently unsuccessful at Long Point where the leopard frog and Fowler's toad are the dominant amphibians and the only ones which appear to be at all plentiful.

Among the reptiles, the apparent absence of the blue-tailed skink (Eumeces fasciatus) and the red-bellied snake (Storeria occipito-maculata) was notable, though the woods on Ryerson island and Courtright ridge appeared to offer ideal conditions for these species.

The most notable features in the reptile fauna were the abundance of the common garter snake (Thamnophis s. sirtalis), and its pronounced melanistic tendency. The fox snake (Elaphe vulpina) and the brown snake (Storeria dekayi) were common. The blowing adder (Heterodon contortrix) which seems to be nowhere abundant in Ontario, was common for the species, six specimens having been taken in eighteen days in 1927 . The water snake (Natrix sipedon) was common though not abundant for its species.

When Mr. LeRay and Dr. Campbell visited Long Point on May 14, 1929 , they collected on Ryerson island and at the Oak ridges and found garter snakes and fox snakes congregated in large numbers at the Oak ridges, where they collected over one hundred and forty snakes, including six blowing adders, in about two and a half hours. On July 13 of the same year few snakes were seen at the ridges, only two fox snakes and about a dozen garter snakes having been taken in three or four hours.

The Oak ridges rise to a height of seven or eight feet above the surrounding marsh affording dry ground even when the water is high. They are unshaded except for a few scattered oaks along the crests, and since they lie in an east and west direction the southern slope would receive the maximum amount of sunshine in the autumn and early spring. The above observations would suggest that large numbers of snakes avail themselves of the protection of these ridges for winter quarters, scattering out over the marsh again when the weather becomes warm and settled.

The turtles are well represented at Long Point. Six species were found. Their relative abundance, in descending order, appeared to be as follows: Blanding's turtle (Emys blandingii), the map turtle (Graptemys geographica), the snapping turtle (Cheledra serpentina), the painted turtle (Chrysemys m. marginata), the spotted turtle (Clemmys guttata), and the soft-shelled turtle (Amyda spinifera).

The list on the following pages includes eighteen species, six amphibians and twelve reptiles. It cannot be positively stated that certain species not included do not occur at Long Point, but if they do, they must be very uncommon. 


\section{Amphibians}

Necturus maculosus (Rafinesque). Mud Puppy.-Two specimens were seen in 1927 , both dead. One was found by the writer on June 7 ; it was decayed and had been partly devoured but the head was still intact. The other was seen by Mr. J. L. Baillie Jr., on June 16, but was considered too badly decayed to be worth saving.

This salamander was evidently not plentiful in the waters of the marsh because between May 25 and the end of June, 1927, while the fishermen were seining for carp not a single specimen was captured.

Triturus v. viridescens (Rafinesque). GreEN NEwT.-Nine young specimens ranging from 32 to $44 \mathrm{~mm}$. in length were taken from under cover on the ground on Ryerson island in May and June, 1927. and four specimens within about the same size limits in July, 1929. They were all of orange or red coloration. No adults were found.

Bufo americanus Holbrook. American TOAD.-This toad was not common. Three specimens were taken in 1927, no others were seen.

Bufo fowleri Garman. Fowler's TOAD.-This was the dominant toad at Long Point and was quite common. It was first noted on the evening of May 30,1927, on the sand beach of Second island and was heard calling from the sand bar pools under an air temperature of $58^{\circ} \mathrm{F}$. and a water temperature of $61^{\circ} \mathrm{F}$. On the evening of June 1 , it was again heard calling with the air temperature at $53^{\circ} \mathrm{F}$., and on the evening of June 3 with air temperature at $63^{\circ} \mathrm{F}$. and water temperatures of $64^{\circ}$ to $67.5^{\circ} \mathrm{F}$. On the night of June 2 , a windy night, when the air temperature dropped to $52^{\circ} \mathrm{F}$ the toads were silent.

The sand bar pool where the toads were observed after dark by aid of a flashlight, had a maximum depth of about ten inches and varied in width from five or six to about fifteen feet. It was formed by the washing up of a low sand bar just beyond the edge of the beach, impounding the water in the area between. It sustained a sparse growth of aquatic grasses on the clean, sand bottom.

The singing males were found in water of from two to six inches deep and would sit or float with the head and shoulders above the surface. One male was found singing on the sand a few feet from the water. Specimens singled out and timed gave calls of from one and a half to two seconds duration with intervals mostly of eight to ten seconds between calls.

During the day these toads would remain buried in the sand of the beach and toward evening could be seen emerging in numbers, leaving little pits of one and a half or two inches in depth. They were mostly of pale coloration resembling that of the sand.

On June 8,1927 , a quantity of spawn was found strewn about 
among the grasses in water one foot deep in a sand bar pool on Ryerson island.

The males were greatly in excess of the females. Out of forty-four specimens in our collections thirty-four are males, four are females and six are young specimens of uncertain sex.

On July 13, 1929, large numbers of recently transformed specimens were found on a flat, sandy area edging on the marsh near the outer beach, but sheltered from it by the high, wooded ridge which separates the marsh from the beach.

Rana catesbeiana Shaw. Bull Frog.-The bull frog was not abundant at Long Point. Its call was heard occasionally in the evenings in June, 1927, but no specimens were seen that year. On July 12, 1929, a few specimens were heard calling near the Long Point Company's cottages and two were collected, they were floating among the reeds in water of three or four feet in depth.

Rana pipiens Schreber. LEOPARD FROG.-Leopard frogs were found to be plentiful toward the western end of Ryerson island. They were seen in the beach pools and in the shallow, marshy water between the wooded ridges. A few were also seen at other parts of the point. Considering the apparently ideal leopard frog habitat conditions which exist in many places on the point, one would have expected to have found them more plentiful than they were. The suppression of their numbers may be due in part to the great abundance of garter snakes.

On May 30, 1927, some leopard frogs were croaking at night in the sand bar pools on Second island. On June 8 a clump of spawn was seen in one of the pools on Ryerson's island, but was apparently infertile and was commencing to spoil.

\section{Reptiles}

Heterodon contortrix (Linné). BLowing AdDER.-Six adult specimens of this species were taken on Ryerson island in 1927, most of them on the sandy beach where they came to bask. They were all of dark coloration with the blotching nearly obscured. Two more specimens were taken by Mr. H. P. Stovell in 1928 and six by Mr. LeRay and Dr. Campbell in 1929.

Elaphe vulpina (Baird and Girard). Fox SNAKE.-This species was found to be common. Seventeen specimens were taken between May 27 and June 12, 1927. About as many, but of the exact number there is no record, were taken by Mr. LeRay and Dr. Campbell on May 14, 1929, and three were taken on July 12 and 13, 1929. Most of the specimens taken were basking in the sun at the time of capture.

In the majority of cases in the writer's experience these snakes would 
not exhibit any excitement or make any attempt to escape when approached. On one occasion the writer was collecting at some logs on Ryerson island, and after working there for about ten minutes discovered a fox snake lying quietly on the grass not more than eight feet away. It was apparently not in the least disturbed by all the movement of turning the logs and stripping the bark. On another occasion a specimen betrayed itself by vibrating its tail in the grass when we passed at a distance of eight or ten feet.

A young specimen about two feet in length taken on Ryerson island on June 2, 1927, later disgorged a bundle of undigested earthworms. This same specimen escaped from its bag in our cabin on the night of its capture and finally found its way into the writer's bed. This method on the part of these snakes of seeking warmth at night was known to the fishermen on the point.

Lampropeltis $t$. triangulum (Lacépède). Milk Snake.-A single specimen of $366 \mathrm{~mm}$. in length was taken by Mr. Stovell at Courtright ridge on June 26,1927 . After capture it disgorged three young shrews, Cryptotis parva, two of which revived later.

Natrix s. sipedon (Linné). WATER SNAKE.-The water snake could hardly be considered as plentiful. Only thirteen specimens were found between May 25 and June 13, 1927. One specimen was found on July 12,1929 .

Storeria dekayi (Holbrook). Little Brown SNake.-This species was common and was taken from under cover on the ground, mostly on Ryerson island. Thirteen specimens were taken in 1927 and fourteen on July 12, 1929.

Thamnophis s. sirtalis (Linné). Garter SNAKe.-This was by far the most abundant reptile at Long Point, and is of especial interest because of the pronounced melanistic tendency which it exhibits. The truly melanistic individuals, which would comprise perhaps thirty-five per cent. of the garter snake population of the point, are of a deep, satiny black with white throats. In some specimens the white had a pale greenish hue and in some it was soiled with brown.

As the time for shedding approaches, the skin loses its intense blackness and becomes dull, the belly becomes milky and the back may become grayish or brownish, sometimes showing a rather faint striping. In preserved material this condition is even more apparent and even brilliant specimens may become dull. Many of the striped specimens found were very dusky, and since the yellow pigment washes out in preservative it of ten becomes a difficult matter to distinguish these from those that were originally black.

In the museum collection there are one hundred and seventy-three specimens from Long Point. Of these thirty-seven are definitely black, 
twenty-seven are dull or faintly striped but show a deep, black under skin where the outer skin has been removed, so there seems to be little doubt that the latter were melanos approaching the time of shedding, making a total of practically thirty-seven per cent. melanos in the collection. At least another twenty-six specimens, though not actually black, show a great excess of black pigment which in some cases almost obscures the striping.

While at Long Point for two days in July, 1929, we decided to collect every garter snake we saw regardless of colour or size. A number escaped, but we secured a total of eighty-six out of which forty-four or 51.16 per cent. were black. The high percentage of melanos in this collection is perhaps due in part to the fact that their colour does not conceal them in the field, they are more easily seen and so less likely to escape.

Females apparently are more abundant than males, and especially so in the case of the black specimens. The thirty-seven definitely black specimens in the museum collection were examined for sex and there were nine males and twenty-eight females. An equal number of definitely striped specimens were examined and there were sixteen males and twenty-one females. In the black specimens, then, we find 75.67 per cent. of females and in the striped specimens 56.75 per cent. of females. In the total of seventy-four specimens examined we find 66.21 per cent. of females.

In the years 1927 and 1929 a total of fifteen pregnant females, nine striped and six black, were isolated in separate containers until after their litters were born, when the numbers of black and striped young in the different litters were counted. (Copeia, Nos. 172 and 1930.1.) The results for these observations are as follows: The nine striped females produced two hundred and forty-eight young of which eighty-eight, or 35.48 per cent. were black. The six black females produced one hundred and thirty young of which sixty-eight, or 52.30 per cent. were black. The total of all young born was three hundred and seventy-eight of which one hundred and fifty-six, or 41.26 per cent. were black.

The yellow striped specimens found at Long Point did not exhibit the brilliant lemon yellow so common in the striping of this species from Lake Ontario northward, but a deep yellow of straw, orange or brownish hue, and frequently rather dull. A few showed red skin anteriorly between the scales of the lateral stripes.

It was noted that many of the garter snakes taken at Long Point were unusually pugnacious and would flatten themselves and strike repeatedly when first handled.

Chelydra serpentina (Linné). SNapping Turtle.-This turtle was common at Long Point and was often caught by the fishermen when seining in the marsh for carp. 
Mr. L. L. Snyder, in his diary for 1927 , records seeing large numbers of them wandering about on Courtright ridge on June 23 and some of them in the act of excavating nests. On June 26 he found that many of the nests had been dug up by raccoons, the tracks of which were plainly evident. These animals had been devouring the eggs and the empty shells were scattered about their diggings. The raccoons did not always steal the full complement of eggs from any nest and a few could be found which were left in the ground undamaged.

Clemmys guttata (Schneider). Spotted Turtle.-Four specimens of this species were taken in 1927 and a few others were reported as seen by the fishermen. Two of the specimens taken were found under a water logged plank in about four inches of water. The dark plank and the water and mud beneath it had accumulated considerable heat from the direct rays of the sun. About twenty specimens were taken on the Oak ridges on May 14, 1929, and others were seen.

Emys blandingii (Holbrook). Blanding's Turtle.-This was the most abundant turtle and it was frequently found wandering about in shallow water in the marsh on Second and Ryerson islands. It was also seen in the marshy ponds between the ridges on Ryerson island. Three young specimens of four inches or less in length were taken in the sand bar pools on the beach. The carapaces of these specimens were covered with algae which is not usually present on older specimens.

Seventeen specimens were taken in 1927 and many others were seen.

$\mathrm{Mr}$. Snyder in his diary for 1927 records seeing large numbers of them wandering about on Courtright ridge on June 23 and digging nests. He records seeing a pair copulating on May 10, 1928.

Mr. LeRay reports that on May 14, 1929, he saw hundreds of these turtles sunning themselves on the Oak ridges, and described them as being "dotted all over the place".

Graptemys geographica (LeSueur). MaP TURTLE.-This turtle was very common at Long Point. Six specimens were taken in 1927 and many others were seen. They would congregate in numbers on certain logs in the marsh where they would bask in the sun, and could be identified through the field glasses. It was impossible to approach them in such places since they would dive while our boat was still three or four hundred feet away. They seemed to be the most wary of the turtles.

Mr. J. L. Baillie, Jr. reports seeing forty-two at one time on the outer beach on July 4,1927 .

Chrysemys m. marginata (Agassiz). Painted Turtle.-Ten specimens of this species were taken in 1927 during the eighteen days that the writer was at the point. It was common though not abundant. Mr. LeRay reports seeing it in about equal numbers with the spotted turtle on the Oak ridges in May, 1929. 
Amyda spinifera (LeSueur). Soft Shelled Turtle.-One specimen of this turtle was taken in 1927 and three in 1928. According to the fishermen, these turtles were not uncommon, but were not often seen except when they came ashore in June to lay their eggs. They were occasionally taken in the fishing nets. 


$$
\text { 3) } 262
$$





of

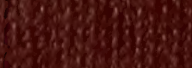

40 6.

6.

36-1.5

10 ons. 